\title{
BIOGRAPHIIES $\mathrm{OP}^{\mathrm{R}}$ \\ SCIENTIFIC MEN \\ A. B, GRIFFITHS, PH, D,
}




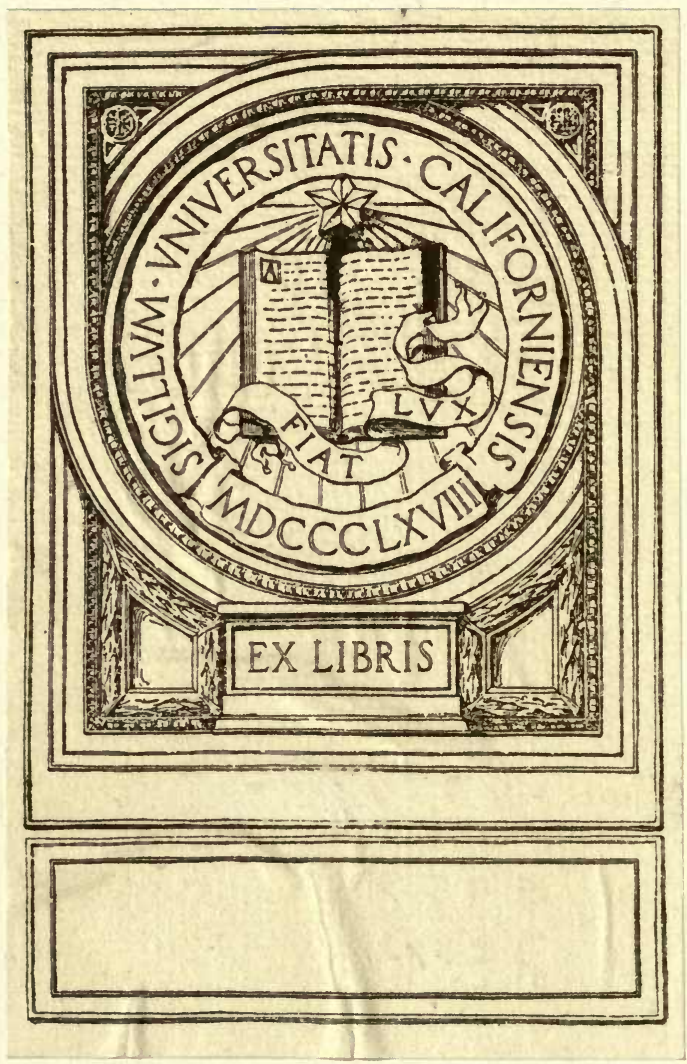





\section{BIOGRAPHIES \\ OF SCIENTIFIC MEN}






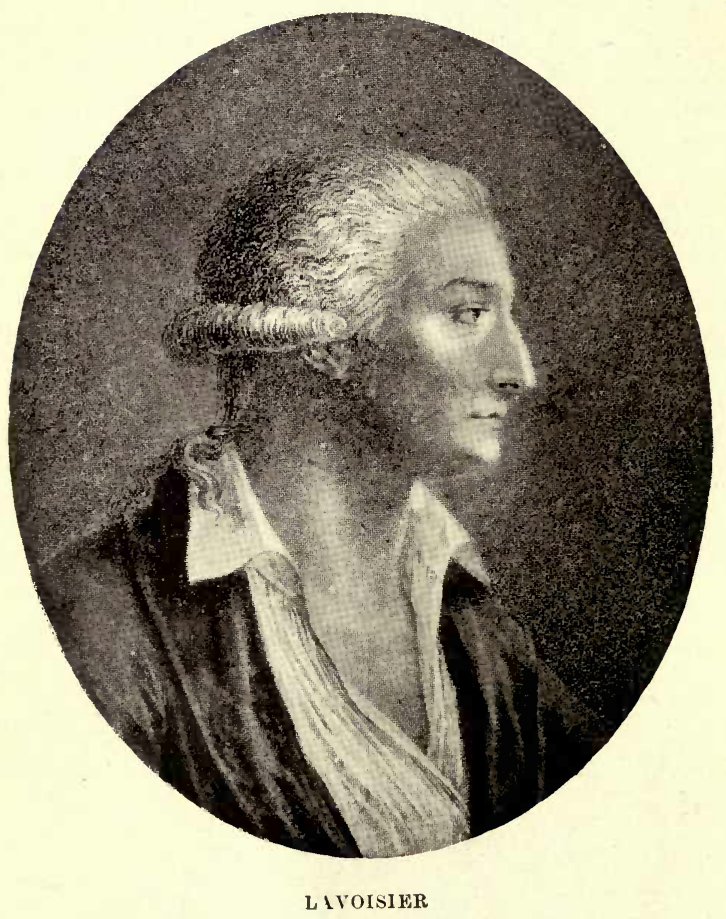

[Frontispiece. 


\section{BIOGRAPHIES}

\section{OF SCIENTIFIC MEN}

By

\section{A. B. GRIFFITHS, Ph.D.}

Gold Medallist and Hon. Member of the Royal Academy of Sciences of Lisbon; Hon. Member of the Academy of Sciences of Montpellier; Gold Medallist

of the Academie Nationale (Paris); Hon. Member of the

Societies of Sciences of Bucharest, Mexico, Biarritz, and

Rio Janeiro; Hon. Member of the Socilte Alchimique

de France; Author of "The Physiology of the

Invertebrata," "Respiratory Proteids,"

"A Manual of Bacteriology,"

"Researches on Micro.

Organisms,"

etc., etc.

\section{ILLUSTRATED}

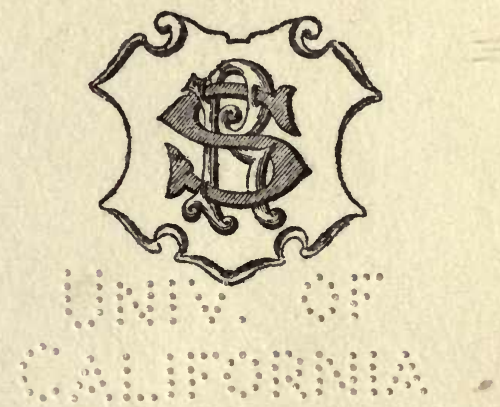

LONDON

ROBERT SUTTON

WALPOLE HOUSE, 28 HENRIETTA STREET, W.C. 


$$
w^{12+1}
$$

$$
\begin{aligned}
& \because \because \vdots \vdots \because \vdots \vdots
\end{aligned}
$$

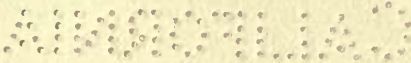


To My Son

Eugène Stephen Griffiths

Tbis JBOok

IS AFFECTIONATELY DEDICATED 


\section{PREFACE}

$7 \mathrm{HE}$ object of the author in writing this book is to exhibit views of the characters and doings of a few of the world's great men of science, and the influence which their work has exerted on the progress of science and civilization.

The biographical, historical, and scientific details have been compiled from the best available sources; original papers, documents, and in some cases autograph letters, etc., have been consulted. There is also a considerable amount of original matter collected in this country and abroad.

The present volume is a "study" of a group of men of science of the eighteenth and nineteenth centuries, their work, and the times in which they lived. "It is only by the study of what has been that we are able to understand what is," and science is no exception to the rule. Historical data add greatly to the interest of science, and dry facts become living pictures. "By following in the very footprints of the great discoverers, by watching them as they make their footing sure, and 


\section{viii BIOGRAPHIES OF SCIENTIFIC MEN}

as they feel their way up the heights," is the correct way to appreciate science-which is destined to rule the world.

In conclusion, the author desires to acknowledge his indebtedness to Dr C. I. Istrati (formerly Ministre de l'Instruction Publique in the Roumanian Government), Mrs Eugénie Strong, Litt.D., LL.D. (Librarian at Chatsworth to the Duke of Devonshire), Eugène S. Griffiths, H. Follows, F.C.S., Miss E. H. Hopkinson, Miss C. B. Wright, G. Jacquemin, and the late A. C. Maybury, D.Sc., M.R.C.S., for information and help in certain parts of the book.

A. B. GRIFFITHS.

"LYNDhURst,"

Barcombe Avenue, Strhatham Hill,

London, S.W. 


\section{CONTENTS}

\section{LAVOISIER}

Birth and Parentage-Education at College Mazarin-An ArocatNouvelle Chimie-Elected a Member of the Académie des Sciences -Introduction of the Balance in Chemical Research-Conservation of Matter-On Calcination-Voltaire's Scientific Work-Explains Combustion - Phlogistic Theory Overthrown-Definition of an Element-Fermier Général-Death Sentence-Prison-His Letter to Augez de Villers-Rejection of his Petition-Marseillaise and Ca Ira-Coffinhal - His Death-Robespierre's and Lamartine's Descriptions of Coffinhal-Carlyle on Lavoisier's Death-Place de la Concorde-Statue of Lavoisier . . . . .

\section{CUVIER}

Birth and Parentage-Education-Private Tutor to the Family of the Comte d'Héricy - French Wars-Ossemens Fossiles - The Abbé Tessier-Professorship at the École Centrale-Classification of the Animal Kingdom-Discovery of Red Blood in Leeches-Professorships at the College de France and the Jardin des Plantes Memoirs on Palæontology-Legons d'Anatomie Comparée-Napoleon establishes Lycées-Secretaryship of the Académie des SciencesHis Honours-Règne Animal-Cuvier made an "Immortal" and a Baron-His Library-Histoire Naturelle des Poissons-La Petite Révolution-His Death-His Grave in the Cimetière du Père la Chaise-Character-Correlation of Growth-Tertiary Mammals of France-His Zoological Researches-Fossil Forms . .

\section{CAVENDISH}

Birth and Parentage-Studies at Cambridge-Character and HabitsCavendish House, Clapham-Weighs the Earth-Law of Inverse Squares-Electrical Resistance of Water-Most Eccentric Character 
of His Time-Composition of Water-A Millionaire-His Evening Walk-Battersea Rise House-Stories about Cavendish-Cavendish and the Doctrine of Stahl-Atmospheric Gases-Discovery of Hydrogen-His Library-His Death and Burial-His HonoursThomson, Lodge, Rayleigh, and Strutt on Cavendish-Galileo and the Church

\section{PRIESTLEY}

Birth and Parentage-Schooldays - Became a Calvinistic Minister -Heterodoxy-Tutor at a Dissenting Academy-Marriage-A History of Electricity-F.R.S.-LL.D.-Pneumatic ChemistryCopley Medal-Appointed Librarian to Lord Shelburne-Visited France, Germany, and Holland-Unitarian Minister in Birmingham -America and the War of Independence-French RevolutionWritings and Speeches against the Established Church-Burke and Priestley-Burke's Reflections on the Revolution in France-Tom Paine's Rights of Man-Mackintosh's Vindicice Gallice-His Letters to Mr Burke-Burning of Chapels and Priestley's House- "Priestley Riots"-Priestley Arrived in London-Manuscripts DestroyedGillray's Cartoon-Pictures in Musée Wiertz, Brussels-Carlyle on the Priestley Riots-Elected a Member of the French Assemblée Nationale-Emigrated to America-Received $£ 2000$ Compensation -Posthumous Honours-His Books-Death and Burial-Discoverer of Oxygen-Phlogistic Theory-Proved Air to be a Mixture- $\mathrm{CO}_{2}$ and other Gases-Ammonia Gas-Prejudiced by Stahl's Doctrine .

\section{LINNAUUS}

Birth and Parentage-His Father's Garden-School at Wexico-Entered the University of Lund-Studied under Stobœus-University of Upsala-His Poverty-Celsius and Linnæus-His ClassificationThe "Artificial System"-The "Natural System" of De CandolleBinomial System of Nomenclature-Systema Naturce-Fixity of Species-Rousseau on Botany-Lectureship at Upsala-Explored in Lapland-His Hardships-Baron Reuterholm-Visited Holland -M.D. of Leyden-Introduced to Boërhaave, Burmann, and Cliffort -Fundamenta Botanica and Bibliotheca Botanica-Visited EnglandGenera Plantarum-Homology-Philosophia Botanica-Floral Clock -Financial Difficulties-Hughes and Wireless Telegraphy-His Marriage-Elected President of the Royal Academy of SwedenProfessorship at Upsala-Rector of Same-Honours-Death 


\section{OWEN}

Birth and Parentage-School Life-Apprenticed-Edinburgh University-St Bartholomew's Hospital-Prosector to Abernethy-Mr Clift and the Royal College of Surgeons-Lecturer at St Bartholomew's Hospital-Owen visited Cuvier in Paris-Owen and Voltaire's Statue-Memoir on the Pearly Nautilus-Huxley's Remarks concerning the Memoir-Catalogues of the Hunterian CollectionProfessorship - F.R.S. - Marriage - Odontography - Sir William Flower on Owen's Anatomy and Physiology of the VertebratesDinornis-The History of British Fossil Reptiles-British Fossil Mammalia and Birds-Researches on the Fossil Remains of the Extinct Mammals of Australia-Extinct Wingless Birds of New ZealandOslerism-His Work in Palæontology-Definitions of Analogy and Homology - Darwinism - His Scientific Imagination - Origin of Species-His Work on the Anthropoid Apes, Monotremes, Marsupials, Apteryx, Dodo, Lepidosiren, Toxodon Platensis, etc.-Huxley's Appreciation of Owen's Palæontological Work - His Comparative Anatomy and Physiology of the Invertebrate Animals-His Letters to the Author-Owen and the Natural History Department of the British Museum-Civil List Pension-Honours-K.C.B.-LL.D. and other Degrees-Medals - Sheen Lodge, Richmond Park (a Royal Residence)-His Character-Herbert Spencer and Darwinianism-Failing Health-Owen's Letter to the Author-Death and Burial-King Edward's Remarks Concerning Owen-Statue of Owen.

\section{LIEBIG}

Birth-Universities of Bonn and Erlangen-Goethe and German Professors-Became a Pupil of Gay-Lussac-Introduced to HumboldtCombustion Analysis-Professorship of Chemistry at Giessen University-Liebig and Wöhler on the Cyanates-Professorship at Munich - Hofmann's Eulogy-His Great Work on Agricultural Chemistry-Birth of the Superphosphate Industry-Mineral Theory of Plant Nutrition-Laws of Husbandry-Liebig's Attack on England-Familiar Letters on Chemistry-Made a Baron-Liebig's Definition of a Compound Radicle-Schorlemmer's Definition of Organic Chemistry-Chloroform-Chloral and Aldehyde-Organic Acids and the Doctrine of Basicity-Liebig and Bromine-Liebig and Mistakes -His Books-Honours-Death . 


\section{LYELL}

Birth and Parentage-Education at Midhurst and Oxford UniversityAttended Lectures of Dr Buckland-Called to the Bar and Practised as a Barrister- "On the Marls of Forfarshire"-Visited France-Introduced to Cuvier and Humboldt-Professorship of Geology at King's College-F.R.S. - The Principles of Geology-Lyell and Lamarck-Darwin and Lyell-Geological Uniformity and Continuity -Definition of Geology-Classification of Rocks-" "On the Volcanic Districts of Auvergne"- "On the Tertiary Formations of Aix-enProvence"-Division of the Tertiary Rocks-His Marriage-Elements of Geology-Travels in North America - Knighted and afterwards Created a Baronet-Refuted the Theory of Elevation Craters-On The Antiquity of Man-The Student's Elements of Geology-Honours -Death-Burial in Westminster Abbey . . .

\section{DALTON}

Birth and Parentage-Education-School Work-Observations upon the Weather-On Vision of Colours-Constitution of Mixed Gases-J. P. Joule-Dalton's Atomic Theory-Law of Multiple ProportionsAvogadro's Law-The Law of Dulong and Petit-Dalton's Manchester Laboratory-Chemistry and Wealth of Nations- "On the Absorption of Gases by Water and other Liquids"-New System of Chemical Philosophy-Atomic Weights-Sizes, etc., of Atoms-Structure of an Atom-Electrons-Rutherford, George Darwin and Smithells on the Atomic Theory-Composition of the Air-As a Lecturer-F.R.S.-Honours-Visited Paris-Civil List PensionHis Character-Imagination (the Value of)-Death-Public Funeral - Posthumous Honours-Statue by Chantrey - Fresco by Madox Brown in the Manchester Town Hall-Dalton Scholarships at Manchester University - Würtz and Dalton's Atomic Theory . .

\section{MENDELEEFF}

Birth and Parentage-Tobolsk Gymnasium-Education at St Petersburg University-Studied in Paris-Teacher and Chemist in the Crimea - Heidelberg - Professorship in the Technological Institute at St Petersburg-Professorship at the University-His CharacterAs a Lecturer-Loyalty to the House of Romanoff - His Estate near Moscow-Principles of Chemistry-The Periodic Law-His Predictions-Mendeléeff's Letter to the Author- "An Attempt towards a Chemical Conception of the Ether"-On Non-Valent Gases-Coronium-On Solutions-Absolute Boiling-Point-Naphtha Production 
in America and the Caucasus-Honours-Mendeléeff and Tolstoi-

Miss Ellison Quoted-Death-The Czar's Telegram-Menschutkin's Sudden Death-Siberia and its Cruelties-Gorky Quoted . .

\section{BUFFON}

Birth-His Wealth-Tour de St Louis-Remarks of Rousseau and Prince Henry of Prussia on the Tour de St Louis-The SorbonneHis Recantation of "Heresy"-Mr Gladstone on Evolution-Histoire Naturelle-Epoques de la Nature-Father of the Modern Evolutionist - Mirabeau, Rousseau, Diderot, Voltaire, and others praised Buffon's Style-His Character-Newton's Fluxions-Paved the Way for the Doctrine of Descent-Action of the Environment-Lowell QuotedBuffon and Modern Evolution-His Vanity-Elected a Member of the Académie des Science-Directorship of the Jardin des PlantesThéorie de la Terre-Comte de Saporta Quoted-Histoire Naturelle des Oiseaux-Histoire des Minéraux-Death-Burial in Père la Chaise -His Grave Desecrated during the Reign of Terror-Huxley's Appreciation of Buffon-Saint-Hilaire on Linnæus and Buffon

\section{BERTHELOT}

Birth and Parentage-Educated at Lycée Henri IV.-Préparateur at the College de France-His Thesis and Degree-Elected Professor of Chemistry in the École de Pharmacie-Professorship at the College de France-Founder of Organic Synthesis-Poincaré Quoted-His Work on Thermo-chemistry-Awarded the Jecker Prize-The Era of Berthelot-Acetylene-Methane-Value of Chemistry-Aerial Navigation-Proved the Alcoholic Nature of Glycerine-Chimie Organique fondée sur la Synthese-Essai de Mechanique Chimique fondée sur la Thermo-chimie-Berthelot's Laws-Berthelot's Agricultural Station and Investigations-His Books-Secretaryship of the Académie des Sciences-Elected a Member of the Académie Française-The Institut de France-President of the Scientific Committee of National Defence during the Siege of Paris-Sur la force des Matieres Explosives-His Various Writings-A Member of the Cabinets of Goblet and Bourgeois-Friend of England-Russia's Jealousy-The Boer War, the German Emperor and BerthelotBerthelot's Memory-Madame Berthelot-Berthelot's Kindness to Scientific Men-Honours-His Scientific Jubilee-The SorbonneHis Historical Books-The Société Alchimique de France-The Finale-Berthelot and His Wife Die Together-Both Buried in the Panthéon-Berthelot and the Bodies of Voltaire and Rousseau 


\section{DAVY}

Birth-Apprenticed to an Apothecary-Acquainted with Gilbert and Beddoes-Pneumatic Institution at Bristol-Forbes's Estimate of Davy-Poetic Powers-Introduced to Coleridge and Southey-Anæsthetic Properties of Nitrous Oxide-Lecturer at the Royal Institution and afterwards Professor-Johnson Quoted-His Lectures-Bakerian Lecture-Elements of Chemical Philosophy-Voltaic Battery-The Wollaston Battery-Napoleon's Remarks-Elected F.R.S.-Elements of Agricultural Chemistry-Salmonia; or Days of Fly-Fishing-Consolation in Travels; or the Last Days of a Philosopher-Rumford and Davy-Heat, the vis viva of the MoleculesNewton's Law-Discovery of Potassium and Sodium-His JoyMetals of the Alkaline Earths-Professor Thorpe's Remarks-His Knighthood-Marriage-Chloride of Nitrogen-The Safety LampCreated a Baronet-His Brilliant Experiments-Death-His Character-Honours - Posthumous Honours. Codnt RUMFord :-The Royal Institution-War of American Independence-Rumford's Marriage-Rumford's Discoveries and Inventions-Rumford's Death and Burial-His Grave Damaged by a Shell during the Commune in 1871 .

\section{GAY-LUSSAC}

Birth-Student Days in Paris-Heine Quoted-Assistant to Berthollet - His First Memoirs-Gay-Lussac and Humboldt's Experiments on the Atmosphere-Nature of Volcanic Gases-Formation of Specular Iron-Professorship at the École Polytechnique, Paris-Chair in the Jardin des Plantes-Dynamics of Earthquakes-A New Process for the Preparation of Alkaline Metals-Recherches Physico-Chimiques - Napoleon and Men of Science-Napoleon and Volta-The Law of Volume-Avogadro's Law-Law of Dulong and Petit-Gay-Lussac's Tower-Boron, Boron Fluoride, and Boric Acid-Action of Light on Gases-Hydriodic Acid and Iodine-Cyanogen-Beeswax Bleached by Chlorine-The Royal Ball at the Tuileries-The Birth of Isomorphism-The Chlorides of Iodine-Dithionic Acid, Sodamide, and the Fulminates-Elected a Member of the Chamber of Deputies - Created a Peer of France-His Physical Discoveries-Law of Gaseous Expansion-His Alcoholmeter, Syphon Barometer, and Apparatus for Ascertaining Vapour Densities-Cours de Physique, Cours de Chimie-Honours-Death-Posthumous Honours-Concluding Remarks 


\section{KELVIN}

Birth and Parentage-Glasgow and Cambridge Universities-Honours at Cambridge-Professorship at Glasgow University-Cooling of the Earth-Natural Philosophy-Sizes of Atoms-J. J. Thomson's Work on Corpuscular Radiations-Law of the Dissipation of EnergyVortex Motions-His Work in Physics-Law of RetardationMirror Galvanometer-Syphon Recorder-The Atlantic CablesKnighthood-Mariner's Compass-Quadrant Electrometer-Tidepredicting Machine-Deep-sea Sounder-Kilowatt Balance-Multicellular Electrostatic Voltmeter - His Fortune - "The Secular Cooling of the Earth"-Bakerian Lecture-His Papers-F.R.S.Copley Medal-Honours-His Marriage-Created a Peer-Orders of Knighthood-Character-His Lectures-His Jubilee-His Views on Nature-Joule's Electrical Researches-Death-Burial in Westminster Abbey-Inscription on the Grave-Kelvin and Electrons or Fractional Atoms-British Association Paper . . . 18 


\section{ILLUSTRATIONS}

LAVOISIER

Death Warrant of Lavoisier

Frontispiece

PAGI

Cavendish and Cavendish House

Priestley and His Statue .

LinNaUS

”

Sir Richard Owen and Sheen Lodge

,

Liebig and the Giessen Laboratory in 1840

Sir Charles lyell, Bart; ·

Dauton and His Tomb

MendeléefF .

Count Buffon

Berthelot

Sir Humphry Davy, Bart. .

Gay-Lussac .

LORD KELVIN

185 


\section{BIOGRAPHIES \\ OF SCIENTIFIC MEN

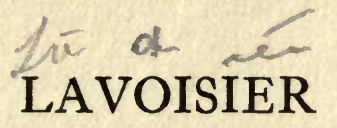

I $743^{-1} 794$

$\mathrm{T}$ the time when so many countries were at war
concerning the succession to the Austrian throne, there was born at Paris, on 26th August 1743, Lavoisier, who was destined in after years to revolutionize chemistry and ultimately to perish, or rather was murdered by the French communists, during the Reign of Terror which accompanied the first French Revolution. Our hero's father was a wealthy merchant, of a scientific bent of mind, and who encouraged the pursuit of knowledge in the son. Lavoisier was educated at the Collège Mazarin, where he studied several sciences; and the knowledge gained in early years was invaluable for his future career. By dint of his genius there rose a nouvelle chimie: "La nouvelle chimie est toujours celle de Lavoisier." Lavoisier is, without doubt, the father of modern chemistry, as he overthrew Stahl's, or the phlogistic, theory; although every science is the accumulation of truths discovered by numerous workers in all ages. 
The doctrines of Aristotle, and Byzantine, Egyptian, Arabian, and "European writers concerning the "four elements" - earth, water, fire, and air-and other nonscientific theories were swept away by the master-mind of the great Frenchman. Even Priestley, Cavendish, Scheele, Macquer, and other distinguished men could not entirely divest themselves of the phlogistic theory; in fact, Black "was the only chemist of his age who completely and openly avowed his conversion to the new Lavoisierian doctrine of combustion."

In 1764 Lavoisier (having been called to the bar as an avocat) gained the prize awarded by the Government of Louis XV. for the best method of lighting the streets of Paris and other large towns, and elaborate experiments on the subject are to be found in the memoirs of the Académie des Sciences- "the greatest scientific body on earth" -as the illustrious Academy has been called by a distinguished American writer; and in 1768 Lavoisier was elected one of its members. Between that date and 1774 he published many papers on chemical, mathematical, and geological subjects-all of which are remarkable for showing the extraordinary ardour and devotion to science of this truly great philosopher. The accuracy of his work and reasoning powers will be found by referring to two of his papers in the memoirs of the Academy for 1770, in which he refutes the idea, held by many, that water could be converted into earth; and it is remarkable that 
in this his first important research he employs the balance - "the essential instrument of all chemical research." He heated water in a closed and weighed glass vessel for a hundred and one days, and at the termination of the experiment found that the vessel had lost $17 \cdot 4$ grains, and on evaporation of the water a solid residue weighing 20.4 grains was obtained - the excess being due to unavoidable experimental error. Lavoisier concluded that water when heated was not transmuted into earth, which was the theory entertained by the alchemists and some of the pneumatic chemists. He proved that the water dissolved some of the constituents of the glass-a conclusion confirmed by Scheele. This research had a far-reaching and an important bearing on the notions or theories of the times-theories that had existed for centuries were to be swept away by his clinching experimental proof of their absurdity; the art of alchemy and the pursuit of the philosopher's stone was rendered futile; but, above all, the experiments proved that the old alchemical idea of the transmutation to be false $;^{1}$ and it led him to

1 That a distinguished chemist should in the twentieth century lecture on "The Transmutation of the Elements," would have seemed absurd and impossible to any of our scientific forefathers. Yet this was the title of a lecture delivered at the London Institution on 28th January 1907 by Sir William Ramsay, who showed the influence of electricity on the break up of matter. Radium has shaken our ideas about the ultimate atom and the elements, and is always, though slowly, breaking up and giving off various products-helium among others. The ultra-violet radiations tend to break up metals. These things, viewed in connection with the latest electrical theories, appear 
enunciate one of the most profound truths in sciencethe non-indestructibility of matter- "rien ne se crée, rien ne se perde de la nature"-matter is everlasting. In every chemical reaction there is no loss of matter, only new forms are produced. This is the basis of every chemical equation known at the present day; and, consequently, it is impossible to overestimate the importance of the conservation of mass, which Lavoisier established by means of the new instrument of precision-the balance; although it had been a philosophic theory of early Greek and Latin writers. The idea of the mass of matter was first shaped into an exact form by Galileo, and more especially by Newton, in the glorious age of the development of the principles of inductive reasoning enunciated by Bacon and Descartes in their philosophical treatises.

In 1772 Lavoisier published the results of his experiments on the calcination of metals, the burning of phosphorus and sulphur, and the increased weight in each case was due to absorption of air, and that when the calces of metals were heated with charcoal they were reduced to the metallic state. Twenty years before these experiments, and twenty-two years before the discovery of oxygen by Priestley, Voltaire came to the conclusion that to be scientific alchemy-the transmutation of the elements. Is it transmutation, or is it dissociation? Are all the elements but one form of matter, plus or minus electrons? It is equally wonderful and profound either way; and one wonders what Lavoisier would have thought of these recent developments of his science. 
the increased weight of iron after being heated in air was due to its absorption of something in the air: "Il est très possible que cette augmentation de poids soit venue de la matière répandue dans l'atmosphère." (See Voltaire's paper in Recueil des Pièces qui ont remporté les Prix de l'Académie royale des Sciences, Paris, 1752, tome iv., p. 171.)

Although Priestley first isolated " dephlogisticated air" or oxygen, it was left for the genius of Lavoisier to first interpret the phenomenon of combustion; and in 1778 (the year that witnessed the deaths of Voltaire and Rousseau within thirty-three days of each other) he established the fact that oxygen was the universal oxidizing principle.

During 1775 and subsequent years Lavoisier expounded his views on the nature of respiration, fermentation, and combustion; and we have to this day excellent sepia drawings by Madame Lavoisier of her husband's experiments on respired air.

In 1783 the composition of water was discovered by Cavendish, and confirmed the same year by Lavoisier and Laplace. Lavoisier was then able to explain the reactions which take place when metals dissolve in acids; and when metals burn to form calces, that oxygen is instrumental in the combustion. From the work of Cavendish, he first clearly stated the compound nature of water, and determined accurately its volumetric composition (Kopp). "Although Cavendish was the first to show that water is 
produced when the two gases hydrogen and oxygen are exploded together, it would yet appear that he did not fully grasp the fact that water is a compound of these two gases; it was left to Lavoisier to give a clear statement of this all-important fact, and thus to remove the last prop from under the now tottering but once stately edifice built by Stahl and his successors."

The nouvelle chimie, based on the theory of combustion or oxidation, was not accepted by the older chemists, and many distinguished workers remained followers of Stahl and his phlogistic doctrine, but unprejudiced and younger minds readily accepted the teachings of Lavoisier - certainly a revolution on the older views of chemical theory. This revolution brought upon him much odium and obloquy - so much so that his effigy was burnt at Berlin as a protest against his antiphlogistic doctrines; yet the same Prussian savants and students a few years later readily accepted the nouvelle chimie, and now his philosophy is the bulwark, the very foundation stone, of modern chemistry.

The following words of a well-known living scientist are applicable in Lavoisier's case: "It is extraordinary how slow people are to appreciate enthusiasm on the part of real workers; and it is a terrible crime to upset preconceived ideas. However, it is satisfactory to feel that one has helped to advance truth and upset falsehood, even should the effort prove painful to a certain section 
of fossilized people who are too lazy to work themselves, and who try to suppress the capacity of work in others." ${ }^{1}$

How few think justly of the thinking few !

How many never think who think they do.

In his Traité de Chimie Lavoisier described more fully the formation of oxides, and the phenomenon of combustion; and he proved (1777-78) that the calces of lead, tin, and mercury are oxides of these metals. But the phlogistic theory was still held by many honoured workers in chemistry, and they believed that in Cavendish's inflammable air (hydrogen) was the long-cherished, but undiscovered, phlogiston. Concerning the solution of metals in muriatic or vitriolic acid with the evolution of inflammable air, these phlogistonists stated that the metals lose phlogiston by the process, and that a calx is a metal minus phlogiston or "metallic spirit"!

The quantitative work of Lavoisier, his weighing and measuring, and the philosophical deductions of his experiments, completely shattered the theory of phlogiston-a theory which prevented the advance of science and proved to be a false doctrine, which unfortunately lasted nearly

${ }^{1}$ Quoted from a letter to the author.

It will be remembered that the late Prof. Hughes was turned from publishing a paper on wireless telegraphy by the unfortunate criticism of the late Sir George Gabriel Stokes, who, with others, failed to appreciate it. One sees now what a discovery Hughes had made, and how it was lost to the world by the mighty authority, if not the intellectual pride, of a distinguished physicist! Was it jealousy or prejudice, or both? Sometimes old men are jealous of the work of younger men (e.g., Davy of Faraday)! 
a hundred years. A theory is only useful when it explains the truths of science and helps the advancement of knowledge. Many theories have disappeared from the realms of science, and many are undergoing modification even at the present day.

About eleven years (1785) after the succession of Louis XVI. to the throne of his grandfather, the phlogistic doctrine was completely overthrown-and this was entirely due to the researches, philosophical deductions, and writings of the great Frenchman.

Lavoisier gave the present accepted definition of an "element," although it may be remarked en passant that the researches of Lockyer, Ramsay, and others in the present day have somewhat modified our views concerning the nature of the chemical elements.

About the years 1785-87 Lavoisier, aided by De Morveau (a convert to the nouvelle chimie), Berthollet, and De Fourcroy, formulated a new system of chemical nomenclature which was greatly needed for the further development of the Lavoisierian chemistry : elements, compounds, oxides (peroxides and protoxides), acids, salts, etc., were defined, thus forming the basis of the chemistry of to-day. Lavoisier was the general who marshalled the isolated facts and co-ordinated them into one harmonious and stupendous whole. The work of the four French chemists and the teaching of Lavoisier were, by the close of the eighteenth century, universally accepted by chemists. 
Lavoisier was the first to attempt the ultimate analysis of organic compounds, by burning these bodies in a stream of oxygen, and collecting the water and carbonic acid produced. This work is of historical interest as being the last performed by the illustrious savant, and just before execution.

But his ultimate right to fame rests on his interpretation of the phenomenon of combustion-that it is not a decomposition but a combination; the indestructibility of matter (conservation of mass); his philosophical deductions of the work of others; the introduction of the balance into all chemical operations; the recognition as elements of those bodies only which yield but one kind of matter; the formation of compounds from elements; his system of nomenclature; and, finally, his work (in conjunction with Laplace) on specific heats. Surely a goodly list, and sufficient to make his name immortal in the history of chemistry.

His energy knew no bounds, and at an early age, twentyfive, he became a fermier général under the Government, and had the right, with others, of collecting the indirect taxes throughout France $;^{1}$ and this position during the

1 Since the time of King Philip VI. of Valois (1328-50), the kings of France allowed the taxes to be farmed; and for this privilege those appointed had to pay the king certain sums of money. They recouped themselves by the money collected. Many fermiers généraux became rich, and in consequence were obnoxious to the poor. The nobles and clergy were exempted from taxation. 
Reign of Terror caused his downfall. He held the post of a fermier général until 20th March 1791, when the Assemblée Nationale suppressed the institution.

Lavoisier was wrongfully accused of mixing with the tobacco "water and other ingredients harmful to the health of the citizens"; and in May 1794-l'an deuxième de la République-he and twenty-seven of his colleagues were arrested; and on 2nd May Dupin ${ }^{1}$ (a member of the Government) brought the charges against the twentyeight officials; and they were condemned to death.

The accused passed the night of 5th May in the dungeons of the Conciergerie, and were to be fed on black bread, but a generous friend, supposed to be Madame Lavoisier, secretly bribed the jailers, and provided the inmates of the prison with better food. This was no easy task, as the sentries were a double row of gendarmes-one on foot, the other on horses - and the passages were poorly illuminated by torches. This was the precaution taken to prevent the escape of the prisoners. Some were located in dungeons, where horrors of the most revolting kind had been perpetrated. Lavoisier and others were placed in the dungeon previously occupied by Marie Antoinette. The night was horrible. Only a few had obtained foldingbeds, without mattresses or bedclothes, and others rested on the bare earth of the dungeons !

1 Dupin was renowned for his inclination for the pleasures of the table. 
On 7th May, on the eve of his death, Lavoisier wrote a letter to his cousin Augez de Villiers in which he said:

J'ai parcouru une carrière assez longue, surtout très heureuse, et je crois que ma mémoire sera accompagnée de quelques regrets et peutêtre de quelque gloire. Que pourrais-je désirer de plus?

Les événements dans lesquels je me trouve saisi m'éviteront, selon toute probabilité, les inconvénients de la vieillesse. Je mourrai dans toute la force de mon àge. C'est encore là un avantage que je dois ajouter à ceux dont j'ai joui.

Si je ressens quelques sentiments pénibles, c'est de n'avoir pas fait davantage pour ma famille, c'est d'être privé de tout et de ne pouvoir donner ni à elle ni à toi aucune preuve de mon affection et de ma reconnaissance.

Il est done vrai que l'exercice de toutes les vertus sociales, que des services importants rendus à la patrie, une carrière employée utilement pour le progrès des arts et des connaissances humaines ne sont pas suffisants pour vous défendre d'une fin sinistre, pour vous empêcher de perir comme un coupable!

Je t'écris aujourd'hui, parce que demain il me sera peut-être pas permis de la faire, et parce que c'est une douce consolation pour moi de m'occuper de toi et des personnes qui me sont chères à ce dernier moment. N'oublie pas de me rappeler, au souvenir de ceux qui s'intérréssent à moi et fais que cette lettre leur devienne commune à tous. Selon toute probabilité, c'est la dernière que je vous écrirai.

Lavoisier had made an enemy of no less a person than Marat. In 1780, the latter wrote a "détestable essai sur la nature du feu," 1 and announced that it had received the approval of the Academy. Lavoisier flatly denied the assertion. This infuriated the hatred of Marat to such an extent that in his pamphlet, L'Ami du Peuple, written in 1791, he says: "Je vous dénonce le coryphée, le charlatan Lavoisier, chimiste, fermier général, régisseur

1 Marat's Recherches Physiques sur le Feu (1780). 
des poudres et des salpètres, qui a mis Paris en prison et a interrompu la circulation de l'air avec un mur. . . ."

De Fourcroy spoke indignantly of Lavoisier's sentence : "L'homme qui auroit illustré son siècle par ses talens, qui auroit répandu ses lumières sur la société, dont les travaux auroient eu pour but d'instruire de rendre meilleurs et plus heureux les hommes, seroit placé dans un même tombeau avec celui qui en auroit fait le tourment ou qui en auriot été la honté !"

Yet De Fourcroy, De Morveau, Monge, and others who were his friends and pupils did nothing to save the head of their master. Jealousy - despicable jealousy - was the cause of these men forsaking their friend. "Sa supériorité," they confessed, stood in their way! They only talked, but did not act; and it is stated that De Fourcroy even contributed, by "sa terrible accusation," to the death of Lavoisier.

Petitions for the commutation of the death sentence were scornfully rejected. The Revolution knew no bounds - "away to the guillotine," "à la lanterne!" were the constant cries during the years of its existence. With tricoloured scarfs and Phrygian caps of crimson cloth they sang as they marched the streets of Paris that terrible song of the "Marseillaise" :-

Allons, enfants de la patrie, Le jour de gloire est arrivé!

Contre nous, de la tyrannie, L'étendard sanglant est levé?

and the murderous levelling song "Ça Ira." 


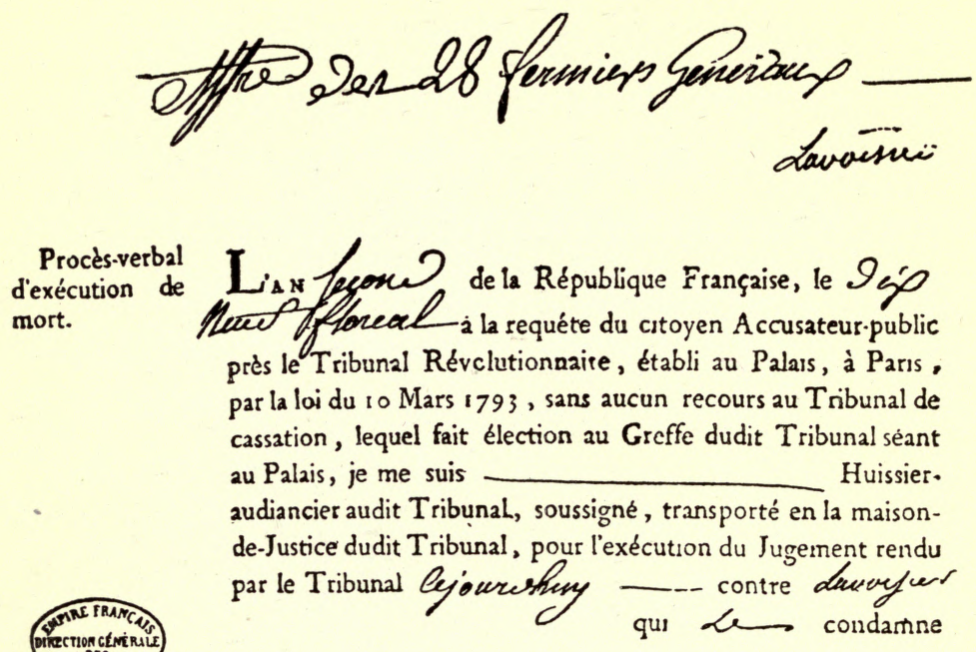

à la peine de mort, pour les causes énoncées audit jugement, et de suite je l' at remis à l'exécuteur des jugemens criminels, et à la Gendarinerie qui L'erne condust sur la place de lanuchaturn ox, sur un échaffaud dressé sur ladite place, 1 ed Luvinuser, en notre présence, subl la peine de mort, et de tout ce que dessus zit taityet rédpóple présent procèsverbab, pour servir et valor grat de r

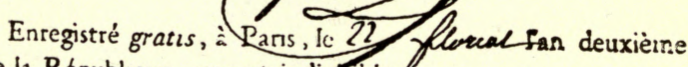
de la République, une et indintisible.

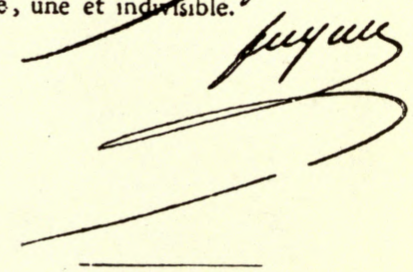

COPY OF THE DEATH WARRANT OF LAVOISIER 
Terrible! terrible in those days! Men and women, tied down to a cart (tumbril), were hurried along the streets to the place of execution. Down clanked the axe, and the head of a victim rolled into the corbeille. The joy of the jealous, black calumnies, devilry, the hatred of cowards, the rage and stupidity of the masses, these were the feelings of men in the year 1794-and they triumphed.

Lavoisier asked for a short time to complete a research in which he was engaged, but Coffinhal (President of the Revolutionary Tribunal) remarked that "la République n'a pas besoin de savants; il faut que la justice suivre son cours."

On 8th May 1794, the immortal Lavoisier was guillotined in the fifty-first year of his age. Calm and resigned, he met his death without flinching, without demonstration, knowing that he had done his duty both to the State and to Science.

Lavoisier was President of the Académie, and a deputation of its members penetrated the prison and placed wreaths on his grave in the Conciergerie. The name of "Lavoisier" required no embellishment, nor was the sculptor's art needed to perpetuate it in posterity.

No lengthen'd scroll, no praise-encumbered stone; My epitaph shall be my name alone.

Byron.

As long as chemistry exists the name of "Lavoisier" will always be remembered as the creator of a new era in science; and as long as the human race is capable of 
estimating the worth of noble labours, so long will the name of "Lavoisier" live, and the memory of him who bore it remain enshrined and held in affectionate reverence by succeeding generations.

Coffinhal, who would not listen to Lavoisier, had, says Lamartine, "the massive frame, figure, and masculine vigour of the Alpine races of his country (an Auvergnat). The energy of his mind responded to that of his muscles. Payan was the head, and Coffinhal the hand, of this night and morrow." And of this man Robespierre said : "You destroy me, you destroy yourself, you destroy the Republic." Ultimately he was guillotined.

Concerning this period Carlyle says in his French Revolution: "The spring sends its green leaves and bright weather, bright May, brighter than ever; death pauses not. Lavoisier, famed chemist, shall die and not live. Chemist Lavoisier was Farmer-General Lavoisier too, and now all the Farmers-General are arrested; all shall give an account of their moneys and incomings, and die for putting water in the tobacco they sold. Lavoisier begged a fortnight more of life to finish some experiments, but the Republic does not need such; the axe must do its work."

To illustrate the feelings, animosities, jealousies, and fiendish propensities of Robespierre and his minions, two coins and a medal of the period ${ }^{1}$ bear ample testimony.

1 In the author's collection. 
The obverse side of one coin has the inscription: "Ludor XVI., D. Gratia" (with the head of Louis); and on the reverse side are the royal arms of France (fleur-de-lis) and the inscription: "1782, Rex Franciæ et Navarræ." The obverse side of the other coin, only ten years later, has the head of Louis and the inscription: "Louis XVI., Roi des Français"; and on the reverse side: " 1792,4 de la lib.," with the royal arms replaced by a floral design. There is a great difference in the title of the king; and the fourth year of liberty is most significant.

The medal is an English one struck in 1794, on the obverse of which is the following inscription: "A map of France, 1794. France divided, throne overthrown, honour trodden under foot, religion 'sixes and sevens,' glory erased, and fire in every corner." And on the reverse is the inscription: "May Great Britain ever remain the reverse."

These were the fanatical times in which Lavoisier lived and worked. Fancy any man of science in these days attempting to do research work during such a general upheaval.

A few words concerning the ever-memorable place of execution will be of interest. The Place de la Révolution, now the Place de la Concorde, the first square in Europe, has a tragic history. Originally a waste ground, it was reclaimed in 1748, after the peace of Aix-la-Chapelle 
(18th October 1748), and a statue of Louis XV. was erected there by the Municipal Council of Paris-the square then receiving the name of Place Louis XV. On 30th May 1770 , at a display of fireworks to celebrate the marriage of the Dauphin, afterwards Louis XVI., with Marie Antoinette, a panic arose which resulted in the death of 1200 persons, and 2000 seriously injured. During the Reign of Terror in 1793 the guillotine was erected on the spot where now stands the Obelisk of Luxor (twin monolith to Cleopatra's Needle). Louis XVI. and Marie Antoinette were among the first victims, and between January 1793 and May 1795, upwards of 20,000 persons were guillotined. In 1799 the famous square was named the Place de la Concorde; it was afterwards renamed after Louis XV., and in 1826 after Louis XVI., and, finally, in 1830 it was again renamed the Place de la Concorde; and it was on the site where the Obelisk now stands that our hero Lavoisier was executed-his work unfinished, but he left a fine legacy to posterity.

His house was in the Place de la Madeleine, Paris; and in 1900 (a hundred and six years after his death) a beautiful bronze statue of him, by Barrias, which rests on a massive granite pedestal, was erected in the same square and opposite the house where Lavoisier lived. The pedestal bears the inscription:--

Antoine Laurent Lavoisier, 1743-1794, le fondateur de la chimie modèrne. Erigé par souscription publique, sous le patronage de 
l'Académie des Sciences. M. Berthelot, Secrétaire perpétuel pour les sciences physiques.

Eleven years after the death of Lavoisier, his widow was married to Count Rumford-the founder of the Royal Institution, London. Two years after the death of Lavoisier, his wife published his Mémoires de Chimie (1796-99), in four volumes; and between the years 1857 and 1896, Lavoisier's Euvres Complètes, in six volumes, edited by Dumas and Grimaux, were published at the expense of the French Government.

We conclude our study of Lavoisier in the words of Galileo: "Ricordiamoci in grazia, che il cercar la constituzione del mondo è de' maggiori e de' più nobili problemi, che sieno in natura." 


\section{CUVIER \\ $1769-1832$}

W

HEN George III. and Louis XV. were on the thrones of England and France respectively, there was born one of the world's greatest naturalists. Georges Chrétien Léopold Frédéric Dagobert Cuvier was born on 23rd August 1769, at Montbéliard, in the Department of Doubs, then belonging to Würtemberg. His father, an officer and a Protestant, retired in order to escape religious persecution, and settled in the town previously mentioned. He had three sons-the eldest died young, the second became the hero of our story, and the third was Frédéric Cuvier (1772-1838), the naturalist.

Georges Cuvier, on account of his delicate constitution, was first taught by his mother-an excellent and praiseworthy woman. At ten years of age he went to school, and there acquired an excellent knowledge of Greek, Latin, mathematics, and other subjects; and at the age of fourteen the Duke of Würtemberg sent him to the Academy of Stuttgart. $\mathrm{He}$ had studied Buffon, and thereby became acquainted with the natural history of 


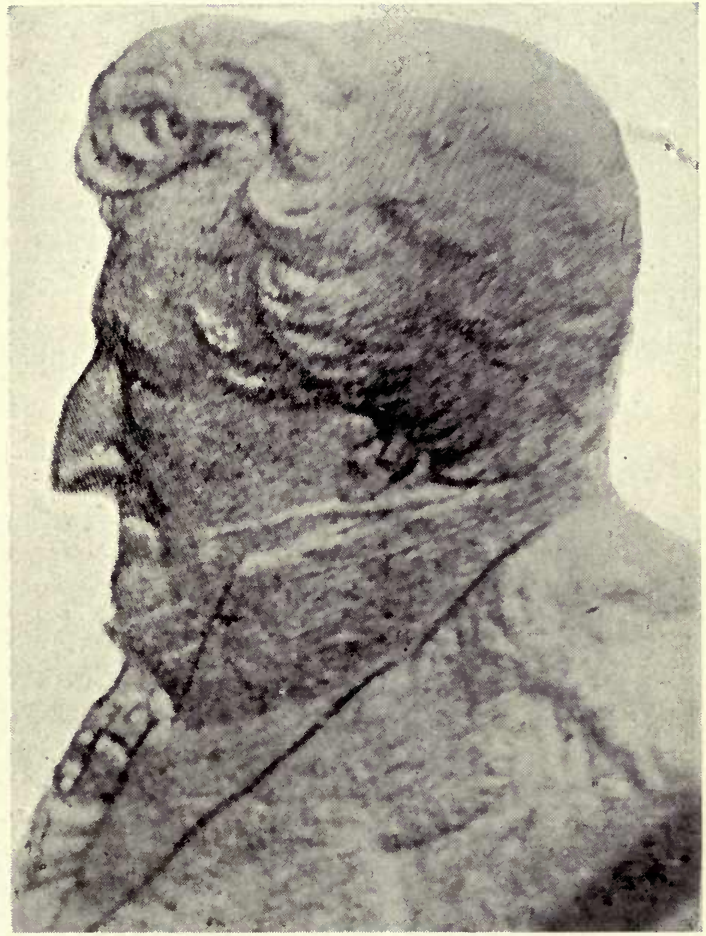

BARON CUVIER 

birds and quadrupeds. His scientific studies were encouraged by one of the professors of the Academy giving him a copy of Linnæus' Systema Naturæ. At this time he was studying philosophy and political economy, natural history, and the German language.

During a period of great anxiety and unrest (namely, in 1788), and at the age of nineteen, Cuvier became private tutor in the family of the Comte d'Héricy, whose estate was near Caen in Normandy. In this position he remained for six years-all through the Great Revolution; in the last year of his tutorship he heard of the execution of Lavoisier (1794), and during the same year his country was at war. The French conquered Flanders, overran the Palatinate, and took Treves; they also took Coblenz, Maëstricht, and Venlo, and nearly the whole frontiers of Holland, and many places in Spain. At the same time the French were defeated by the English in various sea-fights, and lost nearly all their West Indian islands. During this period of storm and unrest Cuvier was working quietly on his favourite subject. In the nobleman's family, besides learning the manners and etiquette of refined society, he was studying with great zeal natural history, comparing fossil forms with living species, dissecting molluscs, classifying animals, etc. It was at this period that he conceived the idea of his two great works, the Ossemens Fossiles and the Regne Animal-and he placed classification on an anatomical 
basis, which was a great stride upon the work of his predecessors. Lamarck arranged the various groups of animals in linear order from lower to higher-a scala naturæ; Cuvier opposed this system, and established the idea of diverging branches (embranchements), although, unlike Lamarck, he was no evolutionist.

While at the Normandy town, with its beautiful cathedral of St Pierre, Cuvier made the accquaintance of the old Abbé Tessier, then hiding from the fury of Robespierre and other revolutionists. Disguised as a surgeon, the learned old man discovered the worth of young Cuvier, and this introduction was the means of putting the latter into communication with Jussieu, Geoffroy Saint-Hilaire, Daubenton, Lapécède, and other men of science.

In 1795 Cuvier was appointed an assistant to the professor of anatomy in the Musée d'Histoire Naturelle. The same year saw him established as professor at the École Centrale du Panthéon - and here he composed his Tableau élémentaire de l'Histoire Naturelle des Animaux - the basis of the modern system of classification of the animal kingdom. At this time Mertrud, aided by the brothers Cuvier, commenced the famous and extensive collection of comparative anatomy at the Jardin des Plantes, Paris; and the next year Cuvier was elected a member of the Académie des Sciences.

In 1796 he discovered red blood in leeches (Hirudo), 
and the following year appeared his paper on the nutrition of insects. ${ }^{1}$

In 1799 he succeeded Daubenton (the collaborator of Buffon) in the chair of natural history at the Collège de France; and finally succeeded Mertrud in the chair of comparative anatomy at the Jardin des Plantes.

In 1800 he published his first palæontological paper, Mémoires sur les Espèces d'Eléphants vivants et fossils, and the quantity and quality of the palæontological work which he turned out is simply astounding.

After the publication of his great work, Leçons d'Anatomie Comparée, in 1802, Napoleon (then First Consul) appointed Cuvier one of the inspectors-general for establishing lycées in thirty towns. At the same time he was elected Secrétaire perpétuel de l'Académie des Sciences (l'Institut de France), and was consequently brought into contact with all the celebrated men of science in the French capital.

In the same year (1804) that saw Napoleon created Emperor and crowned by Pope Pius VII., Cuvier married a widow-Madame Duvaucel (whose husband was a fermier général, and along with Lavoisier and others suffered death by decapitation). His marriage was a happy one.

From 1809 to 1813 Cuvier was sent on an important educational mission to Holland, Italy, and Germany;

${ }^{1}$ See Griffiths' books, The Physiology of the Invertebrata, and Respiratory Proteids. 
and during his sojourn in those countries, Napoleon (then master of Europe) dethroned the Pope, annexed Rome, made Bernadotte King of Sweden, incorporated Holland with France, divorced Josephine and married Maria Louisa of Austria, declared war against Russia, retreated from Moscow, but still alert and intrepid. Such were the times in which Cuvier did work of the highest importance. He was made Chevalier de la Légion d'Honneur in 1811, and three years later a Councillor of State, and in 1812 appeared his monumental work, Recherches sur les Ossemens Fossiles.

During the nine years' reign of Louis XVIII. he was Chancellor of the University of Paris, and held many State appointments. In 1817 he published Règne Animal distribué d'après son Organisation, a work which had the greatest influence upon naturalists, and his system became of world-wide fame.

Cuvier visited London in 1818, and was delighted with the liberties enjoyed by the people in this country, and more than once he alluded to it in his writings. During his sojourn in England Cuvier was made an "immortal" -as a member of the Académie Française is designated. In 1819 he was created a baron.

On the death of Louis XVIII., his brother Charles, the Comte d'Artois, ascended the throne as Charles X., and Cuvier took part in the coronation of that monarch, on which occasion he was promoted in the Order of the 
Légion d'Honneur, was created a Commander of the Order of the Crown of Würtemberg, and received other distinctions.

Three years after the succession of Charles X., Cuvier refused the odious office of press censor, but accepted the position of administrator of the non-catholic religions in France.

Cuvier formed a most extensive library, and permitted naturalists of all nations to work in it. The spirit of jealousy was entirely foreign to his nature. He rejoiced in the discoveries and work of others. "The man who has made a permanent addition to our knowledge of facts has rendered an imperishable service to science," said Cuvier. After his death his library was purchased by the French Government, and it now belongs to the Jardin des Plantes; and the vestibule of the library of St Geneviève contains a fine bust of Cuvier.

In 1828 Cuvier, in collaboration with Valenciennes, commenced the famous Histoire Naturelle des Poissons, which, however, was not completed until after his death.

In 1830 , or the year that saw the abdication of Charles X. (the last of the Bourbon dynasty in France), la petite révolution de trois jours, and the election of Louis Philippe to the throne by the title of King of the French (not as the King of France), Cuvier was in London when the petite révolution was consummated, and remained there two weeks. In 1832 he was created 
a peer of France, and just before his death (which occurred on 13th May 1832) was made Ministre de l'Intérieur. Cuvier died in harness, for he was lecturing at the Collège de France only a few days before his death. $\mathrm{He}$ was buried in the celebrated Cimetière du Père la Chaise, and his funeral was attended by an enormous concourse of people, his death being looked upon as a national calamity.

Cuvier was of a religious nature ; his lectures and speech were clear, precise, and animated, often rising to the highest eloquence; he was a brilliant writer, and an expert draughtsman. In private life he was kind and affable, a lover of order and regularity, and was accessible to all, except during hours of study. He conscientiously performed his various and manifold duties, both to the State and to science, with increasing industry. So vast were his labours that he shortened his days.

Cuvier was the first to indicate the principle upon which the classification of animals should be based-from the standpoint of comparative anatomy. $\mathrm{He}$ was the founder of comparative anatomy, and the discoverer of the law of the "correlation of growth," and was the first to apply this law to the reconstruction of animals from fossil fragments, and hence the student of nature might see pictures of the earliest epochs in the world's history-before the advent of man. To the older zoologist, classification was based on external resemblances, 
but to Cuvier zoology was nothing without comparative anatomy. By founding palæontology, he showed that extinct forms were just as important as living forms in a natural system of classification; and he also showed that the anatomy of recent animals aided in the reconstruction of the fossil forms, these reconstructed extinct animals filling up many morphological gaps.

Cuvier's work in comparative anatomy and allied subjects is a monument of intense labour; his teaching dominated most of the zoology of the first half of the nineteenth century, and his Anatomie Comparée has furnished a model for all students of the science of animal life.

When living at Caen, the digging up of some Terebratulæ proved the necessity of studying fossil with recent forms, and it was these specimens which formed the nucleus of the great collection of natural history objects which he formed, and is now in the Jardin des Plantes. "Palæontological investigations have imparted a vivifying breath of grace and diversity to the science of the solid structure of the earth," says Humboldt in his Cosmos; and if anyone has a right to be called the founder of palæontology, that right belongs to Cuvier, although Lamarck and William Smith were also associated with the foundation of the science of fossil forms. In 1796 Cuvier studied the Tertiary mammals of France, making clear for the first time that fossils were in most cases remains of extinct organisms; and he insisted that 
in any system of classification they must find a place along with living animals.

Although he had distinctly before him the idea of a succession of faunas upon the earth, yet he refused to admit the speculative or philosophical conclusions which were arrived at by his contemporaries Lamarck and SaintHilaire. He firmly stuck to the doctrines of the immutability of species and successive cataclysms. Subsequent events have proved that this was a misfortune, for Cuvier was one of "the most remarkable intelligences of his own or any time."

Although Saint-Hilaire and Cuvier were bosom friends in their youth, their ideas gradually diverged as years rolled on, culminating in 1830 "in the most famous of all scientific duels." Cuvier was a strict, matter-offact man, and could not tolerate the vagaries of the Naturphilosophie school; but in later years he allowed his scientific imagination to run wild by enunciating the doctrines of (1) fixity of species ; (2) emboitement in embryology; (3) physiological deduction as the basis of palæontology; (4) the restriction of natural history to observation and classification; and (5) the successive cataclysms. All these doctrines, and especially the first and last, were destined to be overthrown :-

It must be so, for miracles are ceased;

And therefore we must needs admit the means

How things are perfected.

Shakespeare. 
Embryology, or development, was always neglected by Cuvier and his school, being blind to the fact that embryology must play an important part in philosophie anatomique. This fruitful field of research was left for Wolff, Vicq-d'Azyr, Von Baer, and others.

It has already been stated that comparative anatomy was the basis of Cuvier's zoology, and there are numerous and voluminous memoirs of his on the subject from 1795 to 1831 - the year before his death. Among the subjects investigated may be mentioned: the structure of the larynx of birds, of the nasal fossæ and organs of hearing in the Cetacea (whales), of the organs of respiration in the perennibranchiate amphibia (in the adult state there are external branchiæ combined with lungs), the development of the teeth; and concerning the vertebrata generally he studied respiration, muscular force, animal heat, the brain and intelligence, and the digestive and nervous systems. His labours were incessant.

In 1796 he published his traité on the skeletons of the Megatherium and Megalonyx, and on the skulls of fossil bears; and between 1796 and 1812 he had examined the bones and skeletons belonging to more than forty different species. Cuvier's Xiphodon was about the size of the chamois, light, graceful, and agile, and it belonged to a tribe of animals between the Pachydermata and Ruminantia. Its fossil bones were found in the Upper Eocene strata of France. Cuvier's Palæotherium magnum 
resembled the living tapir in the shape of the head, although it differed in other respects. This animal also lived in Eocene times.

This remarkable man, of a rigidly demonstrative turn of mind, when quite young set himself the task of investigating "the unknown" in zoology and palæontology by means of anatomical research. Linnæus and Buffon had described "the exterior"; Cuvier studied "the interior," and found intimate relation between them. Genius directed his studies, and (like Lavoisier in chemistry) he founded a new era in natural history.

Whilst pursuing his researches on the anatomy of the invertebrata, he soon saw that the animal forms he dissected differed from the fossil forms which lay around him. Palissy and Buffon (in different ages) had noticed the same, and were declared to be dreamers; but Cuvier in his Ossemens Fossiles proved that they were so. His work in this line established the laws of geology and palæontology, and upset many of the fanciful theories of earlier times. As a skilled draughtsman he drew pictures of the ancient fauna of the world's history; and even from a bone, or part of a bone, he ventured to restore the form of a fossil animal-simply from the correlation of parts.

In his last great work, the Histoire Naturelle des Poissons, he described 5000 species of fishes - their affinities, anatomy, and ancient and modern nomenclature. 
apprehension more than pure intellect, or required the exercise of fancy, imagination, affection or faith, was distasteful to Cavendish. An intellectual head thinking, a pair of wonderfully acute eyes observing, and a pair of very skilful hands experimenting, or recording, are all that I realize in reading his memorials," wrote his biographer sixty years ago.

Cavendish was a profound chemist, mathematician, astronomer, electrician, geologist, and meteorologist; and for fifty years he constantly published important papers in the Philosophical Transactions of the Royal Society. Priestley and Cavendish were contemporaries. The work of the former was brilliant and quick; that of the latter was slow and thorough. Although Cavendish wrote much, he had an innate dislike to publicity. He published few papers, destroyed many, and therefore some of his brilliant researches were lost to science. His dread of popularity, want of laudable ambition, lack of enthusiasm, and morbid shyness compelled him to refrain from publishing many important scientific papers. Will there ever be an adequate life of Cavendish? Never. This remarkable man of solitary habits destroyed more papers than he ever published. No doubt the world lost much, for as Sir Humphry Davy said of Cavendish's researches, "they were all of a finished nature, and though many of them were performed in the very infancy of chemical science, yet their accuracy and their beauty have remained unimpaired." 
Cavendish's residences were in Gower Street and Dean Street, Soho, but his favourite home was Cavendish House, Clapham. In the last-mentioned residence (which was demolished in 1905) most of the rooms were converted into laboratories, workshops, and observatories. The author visited Cavendish House and grounds on 9th August 1905, and took several photographs. The house was situated on the south side of Clapham Common, and within its walls one of the most remarkable feats of science was accomplished. Just under the vane (centre window of the second storey) was a small room in which Cavendish weighed the earth.

In 1798 he computed its mean density by comparing the force of terrestrial attraction with that of the attraction of something of known magnitude and density. This done, an approximation of the weight of the earth became possible. The mean of twenty-three experiments was that the earth weighed $5 \cdot 45$ times that of a globe of water of equal size-the accepted figure now being $5 \cdot 50$. This and a vast amount of work was performed within the walls of Cavendish House, which stood in nine acres of beautifully timbered land; and here one of England's greatest chemists "buried his science and his wealth in solitude."

It was in this house that exact quantitative work on electricity received a great impetus by the researches of Cavendish. In 1771 he published important contribu- 
tions to electrical theory, amongst them being an ingenious null method by which the law of inverse squares was proved to a high degree of accuracy. He also was the first to make quantitative measurements in electrical resistance - one of his experiments gave the specific resistance of water as four hundred million times that of iron.

Cavendish, about 1775 , showed that the capacity for a condenser depends not only on its geometrical shape and dimensions, but also on the dielectric employed, and that the capacity is greater when solid dielectrics take the place of air. Cavendish's results were not published at the time, and only verbally did his contemporaries know anything of his work. Sixty-two years afterwards Faraday investigated the phenomena of condensers.

In his wildest dreams, however, Cavendish cannot have anticipated that in less than a century after his death a service of electric cars would be passing Cavendish House. Most likely the recluse would not have liked the prospect if the idea had occurred to him, as he hated "noise and bustle."

Cavendish lived a life of perfect retirement in Cavendish House. Society was a bore to him; he received no strangers, and held no communication with female servants. His horror of women was extreme. He ordered his dinner by leaving a note on the hall table every day; and orders were given that no female servant 
was to show herself on pain of instant dismissal. He had no friends-real friends-only scientific acquaintances, and these had to be very careful how they spoke to him, or he would become perfectly silent and leave their presence. It is said of this remarkable man-one of the most eccentric characters of his time-that he uttered fewer words in the course of his long life than even a Trappist monk.

In Cavendish House he discovered the composition of water, and made other momentous scientific discoveries. Despite his immense wealth (he was the richest man in London in his day), he lived in the simplest fashion, reserving only one or two rooms for domestic purposes.

Cavendish was tall and thin, with wizened features. $\mathrm{He}$ wore old-fashioned clothes-even for the times in which he lived-and a knocker-tailed periwig. He would never sit for his portrait. Our illustration is a copy of a drawing made surreptitiously by a contemporaneous artist.

He was afraid of strangers, and, when introduced to anyone, he fell into a state of the most painful nervousness. It was his custom each evening to take a constitutional walk in a secluded part of Clapham Common, where there was little chance of his meeting anyone else. Strolling there one evening, thinking over some momentous problem, probably lost to the world, he was addressed by a couple of lovers, fell immediately into 


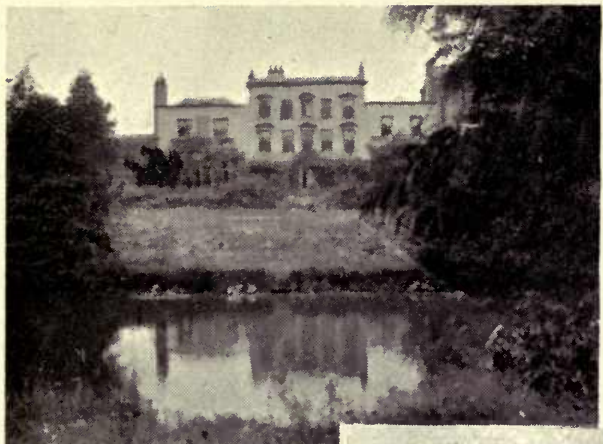

E.S.

HON. HENRY CAVENDISH AND CAVENDISH HOUSE, CLAPHAM
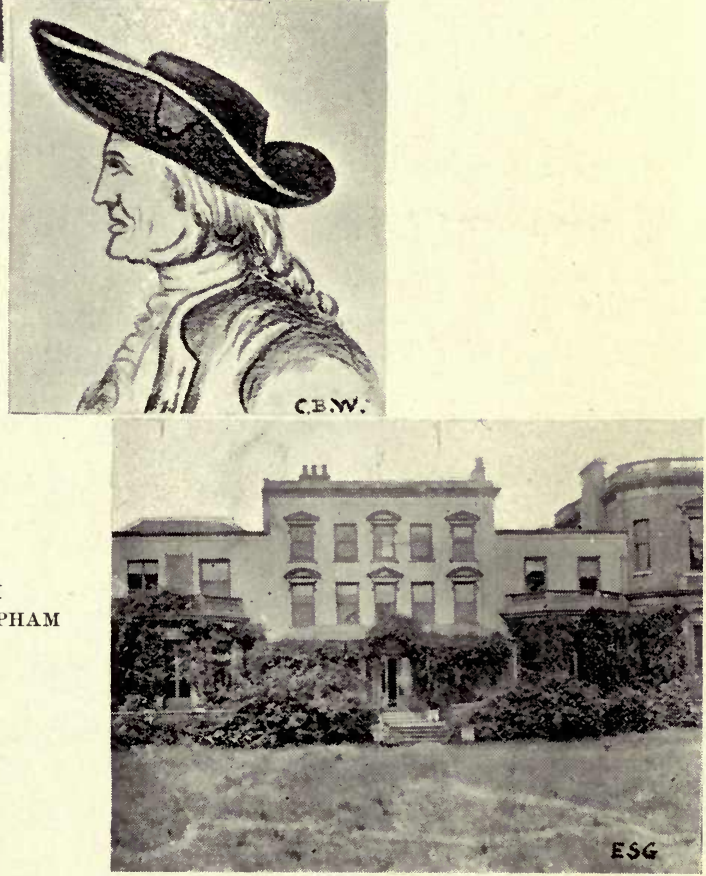

a state of nervous agitation, and in future confined his evening walks to the nine acres surrounding Cavendish House. His shyness was almost a disease, and was extremely embarrassing to himself and acquaintances. If Cavendish had not been such a recluse, he might have taken part in the doings of another famous Clapham house. Cavendish House was No. 100 Clapham Common, and No. 87 was the square and not very picturesque building of the Georgian type known as Battersea Rise House. This house was the rendezvous of Wilberforce, Zachary Macaulay, Thornton, and others of the antislavery crusade, who in their day wielded no small influence upon the destiny of mankind. Cavendish's work, however, lay in another line, for he was no philanthropist or politician.

Many are the stories of this eccentric individual. A few, however, must suffice. Ingenhousz, a distinguished scientist, entered upon a complimentary harangue, saying he had only come to England for the purpose of seeing the great Cavendish-so profound and so universally celebrated. Cavendish became speechless, nervous agitation seized him, and, overwhelmed with confusion, made a hasty retreat from the room, and on reaching his carriage was driven home.

On one occasion three or four friends (or rather acquaintances) being invited to dine with him, he was asked what he would like for dinner. He replied, "a 
leg of mutton." "But," said the servant, "that will not be enough for five." "Then get two legs," was his reply.

Another story is told that Cavendish's banking account had accumulated to the extent of $£ 80,000$, and when his banker asked whether it should be invested, he replied, "Do what you like with it, but trouble me no more about it, or I will place my account elsewhere."

Although a marvellously accurate worker, Cavendish was not free from bias. Like Priestley, he was a phlogistian, and his chemical papers are written in the jargon of the school of Stahl. In 1766 he published his first paper, which was entitled "On Factitious Airs"; but before this time he wrote two papers: "Experiments on Arsenic" and "Experiments on Heat," which, however, due to his horror of publicity, were not published until after his death. In 1788 Cavendish published his famous paper, "Experiments on Air," in which he says: "As far as the experiments hitherto published extend, we scarcely know more of the nature of the phlogisticated part (nitrogen) of our atmosphere, than that it is not diminished by limewater, caustic alkalis, or nitrous air ; that it is unfit to support fire, or maintain life in animals; and that its specific gravity is not much less than that of common air; so that though the nitrous acid by being united to phlogiston is converted into air possessed of these properties, and, consequently, though it was reasonable to suppose that part at least of the phlogisticated air of the atmosphere 
consists of this acid united to phlogiston, yet it might fairly be doubted whether the whole is of this kind, or whether there are not in reality many different substances compounded together by us under the name of phlogisticated air. I therefore made an experiment to determine whether the whole of a given portion of the phlogisticated air of the atmosphere could be reduced to nitrous acid, or whether there was not a part of a different nature from the rest which would refuse to undergo that change. . . . If there is any part of the phlogisticated air of our atmosphere which differs from the rest, and cannot be reduced to nitrous acid, we may safely conclude that it is not more than $\frac{1}{120}$ part of the whole." This is of vast importance, if we bear in mind the discovery of argon as a constituent of the atmosphere by Rayleigh and Ramsay in 1894, and the later work of Ramsay and Travers on krypton, neon, and metargon.

Although Cavendish's work on atmospheric gases was of great importance, it led him to a still more famous discovery, namely, the composition of water in 1781 ; and in his paper of 1784 he says: "By the experiments with the globe it appeared that when inflammable air (hydrogen) and common air are exploded in a proper proportion, almost all the inflammable air, and nearly one-fifth of the common air, lose their elasticity and are condensed into dew. And by this experiment it appears that this dew is plain water, and, consequently, that almost all the inflammable air, and 
about one-fifth of the common air, are turned into pure water." He further showed that when dephlogisticated air (oxygen) and inflammable air (hydrogen) were exploded together, pure water was the result.

Although he proved the composition of water, it does not appear that he viewed it as a chemical compound of the two gases. His phlogistic ideas biased even his clear mind to such an extent that, after the overthrow of the phlogistic doctrine by the work of Lavoisier, he withdrew from any active part in scientific research.

In 1783 , in a letter to Black, James Watt expressed the opinion that "water is composed of dephlogisticated and inflammable airs." A long and bitter controversy raged about the discovery, the priority of which was claimed for Watt. It is now, however, universally ascribed to Cavendish.

Although nitric acid was known to Geber-the eighthcentury alchemist-Cavendish proved (1784-85) the exact composition and mode of formation of this acid. He was remarkable for the accuracy and precision of his experimental discoveries; but any attempt to draw him into conversation was useless. "The way to talk to Cavendish," said Wollaston, "is never to look at him, but to talk as it were into vacancy, and then it is not unlikely you may set him going."

In 1766 Cavendish discovered inflammable air (the hydrogen of to-day), producing it by the action of dilute 
acids on zinc or iron, and he describes its properties in the first part of his paper "On Factitious Airs." In the same paper he discussed the properties of fixed air (carbon dioxide), and proved that fixed air and the air produced during fermentation were the same.

Early in his career Cavendish made researches into the properties of heat-discoveries in regard to specific and latent heat which anticipated those subsequently made and published by Black-but it is said suppressed them that he might not enter into rivalry with the learned Scotch professor. One pauses in wonder to contemplate a man who could give away fame in so easygoing a fashion, and, moreover, was willing to do so.

The life of Cavendish presents a deeply interesting, but difficult, problem for the student of psychology.

His immense library was available to all his scientific acquaintances on condition that they did not disturb the owner; and on one occasion he was induced to allow a fellow-worker of small means to reside in his London library in order to catalogue and rearrange it. After leaving London, the poor fellow was not in the best of health, and was indifferently provided for. It was suggested to Cavendish that he was deserving of "a little annuity for life." "Well, well, well, a cheque for ten thousand pounds, would that do?" asked Cavendish; and a cheque for that amount was accordingly written. This was the only generous act in his long life of eighty years; and he 
died possessed of more than $£ 1,157,000$. He was a selfish cynic, ignorant of humour and of pathos, devoid of all human sympathy; love, joy, sorrow, and pity were absent in his nature; he had a leichenbittermiene; and, with the exception of the highest intelligence, his life was a blank. With his vast wealth he did no good, not even to science, for he left none to further the aims of his favourite pursuits. Cavendish lived alone, worked alone, and died alone!

When near his end, he called his servant to his bedside, and said: "Mind what I say-I am going to die. When I am dead, but not till then, go to Lord George Cavendish and tell him-go!" He ordered the servant from the room, as he wished to be left alone. Shortly afterwards it was found that Cavendish had "joined the majority"- "abiit ad plures." He died in London on 24th February 1810, and lies buried in the family vault in All Saint's Church, Derby. ${ }^{1}$

It has been said of Cavendish that " in extent of acquirements, and in profundity of learning, he was unsurpassed by any of his contemporaries."

\section{Who are the great?}

Those who have boldly ventured to explore Unbounded seas, and lands unknown beforeSoared on the wings of Science, wide and far, Measured the sun, and weighed each distant star, Pierced the dark depths of ocean and of earth, And brought uncounted wonders into birth;

${ }^{1}$ After his death his library and scientific apparatus were removed to Chatsworth. 
Repelled the pestilence, restrained the storm, And given new beauty to the human form; Wakened the voice of reason, and unfurled The page of truthful knowledge to the world. They who have toiled and studied for mankind, Aroused the slumbering virtues of the mind, Taught us a thousand blessings to createThese are the nobly great!

Among Cavendish's other investigations may be mentioned his work on the thermometer and temperatures; he proved that heat was a mode of motion, thereby refuting the material theory. The origin of the "fur" in a tea-kettle was first noted by Cavendish, and the fact that hard waters could be rendered soft by the addition of lime was demonstrated by him. He also proved, by quantitative experiments, that fixed air (carbon dioxide) was heavier than common air, and performed other work on gases. He invented the eudiometer; but his two crowning discoveries were the determination of the composition of water, and the weight of the earth.

Although Cavendish retained the terminology of the phlogistic doctrine, he practically admitted the essential point of the nouvelle chimie of Lavoisier, namely, that calces are compounds of metals and dephlogisticated air (oxygen). He was elected an F.R.S. in 1764, and in 1801 one of the eight foreign associates of the French Académie des Sciences.

Of posthumous honours, the seventh Duke of Devonshire, himself a distinguished mathematician, erected and 
endowed the world-famed Cavendish Laboratory at Cambridge as a memorial to his illustrious ancestor.

Concerning the author's photographs of the now demolished Cavendish House, the following quotations of letters received by him may not be out of place :-

Professor J. J. Thomson, LL.D., F.R.S., Director of the Cavendish Laboratory, says : "I am greatly indebted to you for the very interesting photographs of the house in which Cavendish lived and worked. I shall have them framed and put near a picture of Cavendish we have in the laboratory." Sir Oliver Lodge writes that "they are an interesting reminiscence of a great man." Lord Rayleigh writes: "He was a queer creature in many ways, but I have always had the greatest admiration for his scientific work." The Hon. R. J. Strutt, F.R.S., writes that "the photographs are of much historical, scientific interest, and as a great admirer of the wonderful precision of Cavendish's work, I am very pleased to have them."

Such are the opinions of some of the foremost living scientists concerning the work of Cavendish.

His fortune, already alluded to, went to his cousin, an ancestor of the ninth and present Duke of Devonshire.

In conclusion, Galileo suffered for saying that the earth revolved round the sun, but what would the Roman hierarchy have done to Cavendish for daring to weigh it? 
If the Church punishes in one age, it condones in another. Pope Leo XIII. removed from the Index Librorum Prohibitorum the two works of Galileo-De Revolutionibus and The Dialogues on Motion, one of which asserted that "the earth was not the centre of the universe, nor immovable, but that it moves even with diurnal motion," this being considered "a proposition absurd and false in philosophy and erroneous in faith." Sentence was pronounced on 22nd June 1633, so that the master's great works have been forbidden to the faithful two hundred and sixty-eight years! The whole proceeding was strange and irregular. Pope Urban VIII. did not sign the condemnation. Copernicus (1473-1543), a priest, taught the same doctrine; and Kepler (1571-1630), by his planetary laws, had founded the new astronomy. Galileo (15641642) only confirmed what they had taught. The year that he died Newton was born, in a land where no Inquisition could stay inquiry. Moreover, in England the Copernican theory created no religious alarm!... More imperishable than the marble monument in Santa Croce are the two books liberated from the Index. . . . Cavendish performed a monumental feat in weighing the earth, although one which would have brought him before the members of the Inquisition had he lived in Italy or Spain in the sixteenth century! 


\section{PRIESTLEY}

\section{3-1 804}

$\mathrm{D}^{\mathrm{c}}$ URING the reign of George II. and six years before the war with Spain, Joseph Priestley was born on 13th March 1733, at Fieldhead, a hamlet near Leeds. He was destined to be a remarkable man in more ways than one, whose work will live as long as time endures, and whose moral character was above reproach.

Priestley's father was a cloth dresser, and his mother a farmer's daughter. The mother dying when Priestley was seven years old, the home, managed by his father's sister, became the meeting-place of numerous dissenting ministers, who helped to mould the character of the boy, for in after life his work became divided between science on the one hand, and theology, metaphysics, and politics on the other. During his schooldays and subsequently he acquired a knowledge of Latin, Greek, Hebrew, Syriac, Chaldean, Arabic, French, Italian, and Dutch; also logic, metaphysics, mathematics, and natural philosophy. Although not blessed with the best of health, he was always of a cheerful temperament, so much so that he 

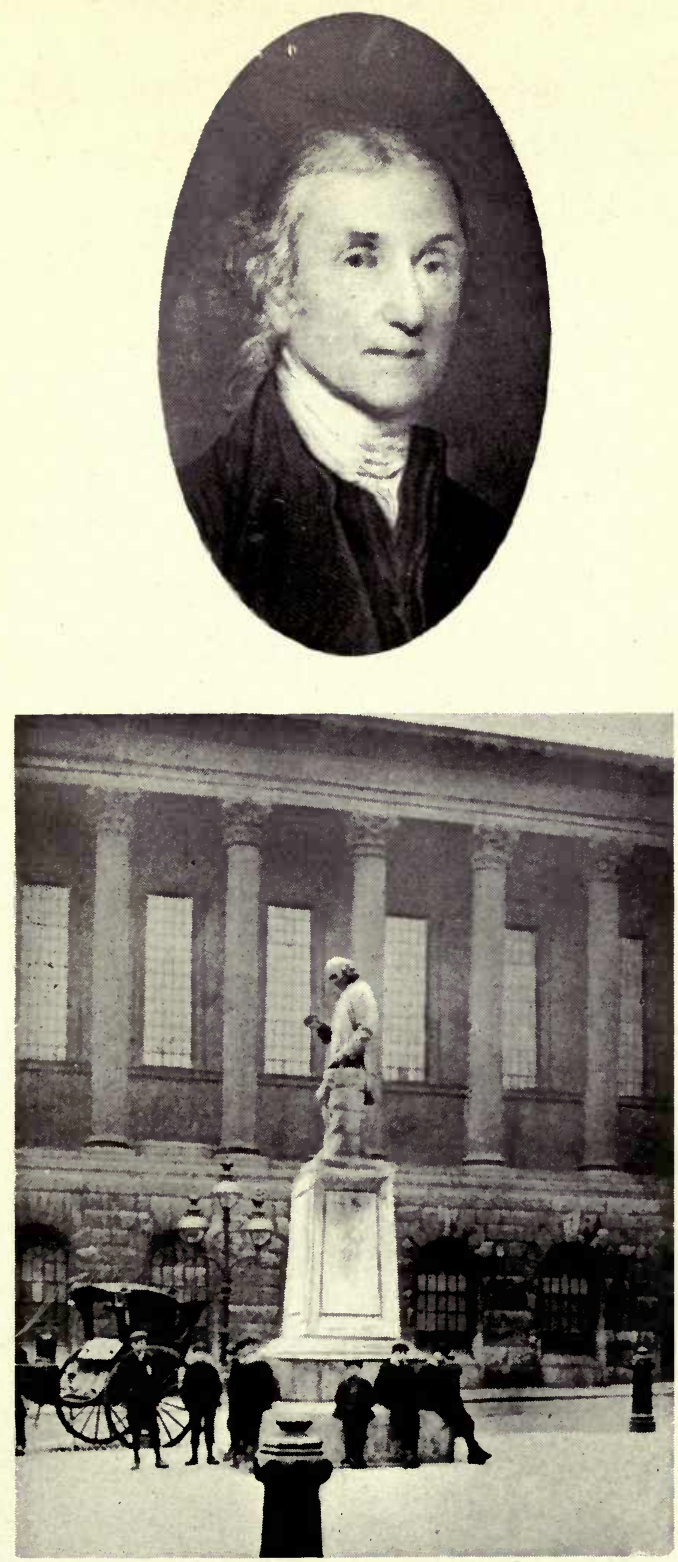

JOSEPH PRIESTLEY ANI) HIS ST ATUE IN BIRMINGHAM 

even looked upon ill-health as an advantage rather than the reverse, because with health he says he might have been fond of sports, and occupied his time in other ways than in studies. Anybody reading Priestley's memoirs will see that he was no believer in the old adage "mens sana in corpore sano."

In the year 1752 , or when he was nineteen, he went to the Dissenting Academy at Daventry, and at this institution developed the power of free discussion on most subjects, especially theology : and as Priestley tells us in his Autobiography, he was generally on "the heterodox side of almost every question."

After three years at the Academy, namely, in 1755, Priestley became a Calvinistic minister at Needham Market in Suffolk; but whether it was due to his heterodoxy or to his stuttering, the congregation left him, and he was obliged to seek fresh pastures. Too great to be fettered by rules, too original to condescend to imitation, he consulted his own inspiration only, and, like other workers, had to pay dearly for living apart from the general weal of mankind. After other vicissitudes, he removed in 1761, one year after the succession of George III. to the throne of his ancestors, to Warrington, having been appointed tutor of languages in a dissenting academy. Here he gave instruction in Latin, Greek, Hebrew, French, and Italian, and lectured on logic, on elocution, on the theory of language and universal grammar, on oratory 
and criticism, on history and general policy, on civil law, and on anatomy. A goodly number of subjects, but Priestley was a most versatile man, as the catalogue of his 108 books published in 1794 bears witness. During his six years' residence at Warrington, he married the daughter of Isaac Wilkinson, an ironmaster of Wrexham, and the union proved a happy one. In 1766 he became acquainted with Benjamin Franklin ${ }^{1}$ (who lived in Craven Street, Strand, London). The acquaintance ripened into friendship. Franklin encouraged Priestley in his philosophical pursuits, and no doubt this was the origin of his electrical researches, which were subsequently published in his History of Electricity. This work greatly enhanced his fame, and gained for him an F.R.S., and the degree of LL.D. of Edinburgh University.

In 1767 Priestley left Warrington for Leeds, having been appointed minister of Millhill Chapel. In the Yorkshire town he commenced his chemical investigations, at the same time freely expressing his opinions on theology and metaphysics. Living near a brewery, he made experiments on the "fixed air" (carbon dioxide) of Black, and this led to investigations with "airs," or, as we should say, with gases. Priestley's chemical work was essentially in the domain of pneumatic chemistry. In 1772 he published a work on the method of impregnating water with fixed air-hence the birth of the mineral water

1 Born 1706; died 1790. 
industry. In the same year he presented a paper to the Royal Society entitled "Observations on Different Kinds of Air," which secured for him the Copley medal.

Having published a method of preventing scurvy, a proposition was made to Priestley that he should accompany Captain Cook in his second voyage to the South Seas. It was accepted, but not confirmed by the Board of Longitude. On the Board were many clergymen, and no doubt they were against Priestley's "religious principles."

In 1772 Priestley was appointed librarian to Lord Shelburne (afterwards Marquis of Lansdowne) at a salary of $£ 250$ a year, a house, and an annuity for life. He remained in the service of his lordship for seven years, living sometimes at Calne, and sometimes in London; and during this time he travelled in Germany and Holland, and in 1774 visited Paris, where he made the acquaintance of Lavoisier and other French savants. Why Priestley severed his connection with Lord Shelburne will never be exactly known, but his lordship treated him with the greatest kindness and consideration.

The publication of Priestley's Disquisitions relating to Matter and Spirit in 1777 brought him much odium theologicum, because it was a powerful exposition of materialism. Critics denounced him as an atheist, as an infidel, and other epithets were hurled at him from all parts of the country. It is probable that this denunciation was the cause of Priestley leaving the service of Lord 
Shelburne. His lordship, however, punctually paid the annuity of $£ 150$ a year which he had promised.

After leaving Lord Shelburne in 1779, Priestley visited London, but ultimately settled in Birmingham, having been appointed Unitarian minister to the Old Meeting Chapel (no longer in existence-New Street Station is on the site of Priestley's chapel). At this time he was friendly with Watt, Wedgwood, Boulton, Darwin, the Galtons, and others. Mrs Schimmelpenninck (née Galton) described Priestley as "a man of admirable simplicity, gentleness, and kindness of heart, united with great acuteness of intellect."

He resigned his charge in 1791, when his friends raised a sum annually for him, in order that he might be able to prosecute his investigations without the necessity of teaching. During this period, although he published a rast amount of chemical work, he could not leave theology, metaphysics, and politics alone. Sympathizing with the Americans in the War of Independence, and afterwards with the French in the Revolution, and his writings and speeches against the Established Church, brought him into controversy with the clergy of Birmingham. The controversy was bitter and long. Priestley was regarded as a dangerous character, an enemy to Church and State, and even Burke (1729-97) spoke against him in the House of Commons. Such was the feeling against dissenters"fomenters of sedition"; but that is far from being the 
end of the story. The storming of the Bastille was almost as much applauded in London as in Paris, but the burning, the plundering, the executions in the name of justice, by which the politest nation in the world seemed to be degrading itself by acts which would disgrace a horde of savages, soon alienated most Englishmen. The times were troublous ones, still the city of Paris maintained its round of gaiety undisturbed; for "Paris is a volcano with two craters, one of passion and one of pleasure." On the still fresh ruins of the grim Bastille, now demolished for ever, Frenchmen danced with glee. It was one way of showing that the ancient régime had for ever disappeared. The Revolution was accomplished amid song and dance-the "Marseillaise" and the "Carmagnole." In this country party passion ran high. Burke published his Reflections on the Revolution in France, in which he denounced in eloquent and impressive language the terrible doings in France. This book called forth many rejoinders, of which Tom Paine's Rights of Man, and Mackintosh's Vindiciae Gallice are the most remarkable. We can see the reason why Burke spoke against Priestley; his opinions were considered heretical and violent. Priestley had written with great fierceness against the episcopacy and ecclesiastical governments generally, and regarded all civil establishments of Christianity, and all connections between Church and State, as abuses and barriers to the propagation of truth. Consequently, he and his friends rejoiced 
at the advent of the French Revolution; when abuses of every description would be swept away, and the beginning of happy days for the human race. Priestley was at loggerheads with the Birmingham clergy on account of his opinions on theological matters, and with laymen he made enemies owing to his contemptuous allusions to King George III. and the royal family.

About this time Priestley was elected one of the eight foreign associates of the Académie des Sciences de Paris (the blue ribbon of science), and was, therefore, brought into correspondence with many savants who supported the Revolution in its early stages, and this fact only helped to add fuel to the fire that was even then smouldering.

Priestley was sorely hurt by the publication of Burke's book, and replied by publishing his Letters to Mr Burke, in which he maintained that the old aristocratic system, embracing both civil and ecclesiastical matters, was beginning to totter at its foundation-due to the salutary effect of the French Revolution. This exasperated the men of Birmingham, who were loyal to Church and King. They became furious, and all sorts of terms of vituperation were hurled at Priestley: he was "a chaos in miniature, not worth God's notice." A verse to the national anthem is well worth quoting here :-

Gunpowder Priestley would

Deluge the throne with blood,

And lay the great and good

Low in the dust. 
Thursday, 14th July 1791, the second anniversary of the taking of the Bastille, was celebrated by eighty of Priestley's friends in Birmingham by a dinner at an hotel in Temple Row, and in spite of the plainest symptoms of an intended riot. "Church and King," "Down with Dissenters," were heard everywhere. These cries exasperated the mob to such an extent that they smashed the windows of the hotel, and burnt the chapels and houses of the dissenters. The full hatred of the mob was directed against Priestley, who, with his wife and family, narrowly escaped with their lives, leaving his valuable library, philosophical instruments, furniture, and the manuscripts of works which had cost him years of labour a prey to the flames.

Several persons were arrested for this disgraceful riot, and three were executed.

The riots may be looked at from two standpoints: either as a struggle to preserve the privileges of the Church of England, or as a rebellion of an excited contingent of the population enraged by the party spirit of the times. Meetings had been organised which were declared by some to be dangerous to the peace of the country. The spirit of democracy had spread in England, and those in favour of the French Revolution entertained the idea of overturning the Constitution of the Empire. Inflammatory pamphlets had been issued and circulated in Great Britain in favour of upholding the doctrine of the Revolution. 
Priestley's New and Old Meeting Houses were burnt to the ground. News of this was conveyed to Priestley at Fair Hill, who thought it so improbable that he should be molested that he hardly credited the story. He was at last prevailed upon to leave the house, but having no apprehension with regard to his property, neither collected any of his manuscripts nor took anything with him. Detachments of the rioters now proceeded to Priestley's residence; they attacked the building with great violence, destroying pictures, furniture, etc., including a valuable library. It was hoped the laboratory would escape the attention of the crowd, as it was situated at some distance from the house, but this was not so ; it was broken into, much valuable apparatus being ruined, and the building destroyed.

On the following morning various parties of the rebels entered the town and paraded the streets armed with bludgeons, vociferating "Church and King," words which the peaceful inhabitants chalked on the doors and shutters of their houses to aid security. The Earl of Aylesford, who had done his best to quell the disturbance, went to the ruins of Priestley's house and addressed the mob. He brought them into the town and tried to persuade them to disperse, but both his efforts and those of the magistrates were useless to stop the revolt.

During the day several residences were attacked and burnt, and in consequence additional constables were 
sworn in; but these were of little avail against the large numbers of the disturbers of the peace. The spirit of rebellion continued to spread, much to the terror and distress of the whole town. While the work of destruction was going on, cries such as "Long live the King and the Constitution in Church and State," "Down with all abettors of the French Revolution," could be continually heard. The devastation went on until Sunday afternoon, when information was received that troops were approaching Birmingham. About ten o'clock three troops of the 15th Regiment of Dragoons from Nottingham, attended by magistrates, entered the town and halted at the Swan Inn. The arrival of the military reassured the inhabitants and eventually restored order.

In the meantime Priestley, on leaving his home at Fair Hill, only went to neighbouring houses a little distance, but hearing that the rioters were advancing, went to Heath Forge, five miles from Dudley. Here he considered he was safe, but news reached him that he was pursued; in consequence he proceeded to Kidderminster; here, again, he proved to be too near his enemies, so Worcester was his next halting-place, and from thence he proceeded to London, which he reached on 18th July 1791.

To the man of science the destruction of his library was the greatest grief. The manuscripts which he most deplored were the following :- 
1. Diaries from 1752 .

2. Several commonplace books containing notes.

3. Register of philosophical experiments and hints for new ones.

4. Sermons, prayers, etc.

5. Notes and a paraphrase on the whole of the New Testament excepting Revelation.

6. A new translation of the Psalms.

7. Memoirs of his own life, to be published after his death.

8. Illustration of Hartley's doctrine of Association of Ideas, and further observations on the human mind.

Concerning the Priestley riots Gillray ${ }^{1}$ produced an etching in which Priestley was grossly lampooned. The sympathy of Priestley and his friends for the French Revolutionists became their greatest crime in the eyes of their enemies, and the dinner on 14th July was ostensibly made the occasion of the anti-Jacobin outbreak. "By far the greatest crime of all which Dr Priestley and the 'Socinians' had committed," says Mr Dent, "was that of sympathizing with the lovers of freedom who had just succeeded in overturning the throne of Louis XVI. in France. This sympathy Gillray, the caricaturist, turned to account in a bitterly hostile and infamously libellous

1 James Gillray (1757-1815) went mad in 1811 chiefly through intemperance, and only had a few subsequent intervals of sanity. 
print, representing the leading Jacobins of the day drinking 'a Birmingham toast' proposed by Dr Priestley. 'The-Head here!' i.e. in a Communion salver, which he holds aloft, himself drinking the toast from a chalice. The Jacobins are represented as early welcoming this toast. Sheridan pouring out a fresh glass of sherry, of which he has already emptied several bottles, is made to say, 'I'll pledge you that toast.' . . . Sir Cecil Wray, frugally drinking small beer, exclaims, ' $O$ heavens! why, I would empty a Chelsea pensioner's small-beer barrel in such a cause.' Fox, as chairman, with punch-bowl before him, cries, 'My soul and body, both upon the toast.' Horne Tooke, who sits next him, drinking gin, says, 'I have not drunk so glorious a toast since I was parson of Brentford'; while in the corner opposite Dr Priestley, his co-religionist and bosom friend Dr Theophilus Lindsey cries 'Amen! Amen!' as he drinks the toast in brandy. In the background are several cadaverous-looking pietists, supposed to represent Dr Priestley's congregation. The print is exceedingly vigorous in design and execution, but as full of venom as an etching from Gillray's needle could possibly be."

Seeing this etching, reminds one of many of the venomous, satirical, and revolting paintings of Antoine Wiertz in the Musée Wiertz in the Rue Vautier, Brussels (e.g. "Napoléon dans l'Enfer," "L'Enfant Brule," "L'Inhumation Précipitée," etc.). 
The reference to "The-Head" arises from the fact that in the centre of the table at that ever-memorable dinner of 14th July 1791, was a painting of the King, and on both sides a marble obelisk, the one representing French liberty breaking the fetters of despotism, and the other English liberty in its present enjoyment.

Such were the feelings against Priestley by his own countrymen, and as Carlyle says in his French Revolution - did not iron Birmingham, shouting "Church and King' - itself knew not why - burst out into rage, drunkenness and fire, and your Priestleys and the like dining there on the Bastille day get the maddest singeing -scandalous to consider!" The French, more tolerant, naturalized Priestley and other foreign friends of humanity; and in September 1792 he was elected a member of the Assemblée Nationale by the Orne Department in Normandy. He wisely declined the honour, as the guillotine was no respecter of persons-not even " the friends of humanity."

Priestley came to London, and although elected minister of a congregation at Hackney, he felt the insecurity of his position. He was boycotted by his scientific friends, by tradespeople, and his own servants feared to live under the same roof. Finally, he emigrated to the United States of America, where he landed in 1794. He settled at Northumberland, a quiet town on the banks of the Susquehanna in Pennsylvania; and with all his 
suffering and injustice, he left his native land "without resentment or ill-will," knowing too well that the time would come when Englishmen would do him justice. He died on 6th February 1804, and lies buried near his new home.

If Priestley could have seen that his friend Lavoisier and Bailly (the astronomer) would be sent to the guillotine, he would have modified his views of the liberty, fraternity, and humanity of the French Revolutionists. Priestley received $£ 2000$ to atone for mob violence-the Birmingham revolution of three days; for poor Lavoisier and Bailly the only compensation is the sorrow of all intellectual men and women.

In the end, Priestley's political and theological heterodoxy helped to make England what it is. He was scorned in England, honoured in France, and found peace in America. Posthumous honours have been instituted to his memory. A statue at Birmingham, representing him in the act of decomposing red precipitate, was erected in front of the Town Hall ; another at Leeds; a chemical scholarship bearing his name is awarded by the Birmingham University; and a beautiful fresco on the walls of the Birmingham Town Hall represents him entering a coach in order to place himself and family out of reach of the infuriated mob, egged on to do their nefarious work of destruction by political and religious foes.

Some idea may be formed of the vastness of Priestley's 
work by mentioning the titles of some of his books: Observations on Air; The First Principles of Civil Government; Disquisitions relating to Matter and Spirit; On Oratory and Criticism; On the History and Present State of Discoveries Relating to Vision, Light, and Colours; The General History of the Christian Church; the Doctrine of Philosophical Necessity; The Harmony of the Evangelists in Greek; The Rudiments of English Grammar; Experiments on Different Kinds of Air; An Introduction to the Theory and Practice of Perspective; A History of Electricity; The Doctrine of Phlogiston Established (one of his last publications), etc.

With all his faults, sympathies with American and French Revolutionists, heterodoxy, prejudices against antiphlogistians, he was a manly man, devoid of mean acts (which cannot be said of many of his foes), a great worker, brilliant experimentalist, a learned writer, a kind and genial friend, and a great controversialist in the domains of theology, metaphysics, politics, and natural philosophy. He was the father of pneumatic chemistry, but more anon. He never could free himself of the false doctrine of phlogiston; but in the words of Voltaire : "oublions les rêves des grandes hommes et souvenons nous des vérités qu'ils nous ont enseignées."

The truths which Priestley contributed to chemistry have now to be described; but, before doing so, it may 
be remarked en passant that he lived in a great age, an age remarkable for great names, which recall to the mind great ideas: Swift, Voltaire, Rousseau, Johnson, Hume, Goldsmith, Gibbon, Goethe, Schiller, Burns Chatterton, Franklin, Mirabeau, Pitt, Talleyrand, Napoleon, Nelson, Washington, and a host of others more or less great lived in the same age as Priestley; and what pictures these names conjure to the thinking reader!

Although many of his works will perish as time rolls on, his chemical discoveries will remain for ever.

Joseph Priestley's name will live as the discoverer of oxygen. It is curious that Priestley himself was so wedded to the doctrine of Stahl-the phlogistic theory - which supposed the existence of a subtle principle, phlogiston, that he did not appreciate the vast importance of his own discovery, and his attitude led Cuvier when pronouncing his éloge (at the time of his death) before the Académie des Sciences, to describe him as "le père de la chimie modèrne qui ne voulait pas reconnaître sa fille."

On 1st August 1774 Priestley discovered oxygen (dephlogisticated air) from red precipitate (mercuric oxide), which gave chemists a new gas of wonderful properties, only to involve chemical processes into great confusion and deeper mystery. The fire air (oxygen) of Scheele, recorded in his Chemische Abhandlung von der Luft und dem Feuer, brought some light into the chemistry of air; but their discoveries were enveloped in darkness-the jargon of 
the phlogistic doctrine-according to which metals lose something (phlogiston) when calcinated (dephlogisticated). The true explanation of combustion (oxidation) and deoxidation was left for Lavoisier to interpret. Priestley was the workman, Lavoisier the philosopher. The discovery placed in the latter's hand became perfect and in harmony with the universal laws of nature; and a revolution in chemistry was accomplished exactly corresponding to that effected by Copernicus in astronomy nearly four hundred years ago.

Priestley seemed " to look on all 'airs' (gases) as easily changeable one into the other," a kind of transmutation. During his lifetime he examined the burning of candles, the respiration of animals upon air, the action of living plants on the air, and invented the pneumatic trough (and used both water and mercury therein). He prepared nitrous air (nitric oxide) dephlogisticated nitrous air (nitrous oxide of the dentist), and carbon monoxide. He used mercury in many of his pneumatic researches, collected alkaline air (ammonia gas), vitriolic air $\left(\mathrm{SO}_{2}\right.$ gas), marine acid air ( $\mathrm{HCl}$ gas), and fluor acid air $\left(\mathrm{SiF}_{4}\right)$. In 1772 he proved that common air was a mixture. By burning charcoal in it he obtained fixed air $\left(\mathrm{CO}_{2}\right)$, which on absorption left a residual (phlogisticated) air incapable of supporting either respiration or combustion. Again, Priestley could not see the importance of his discovery, namely, that air is a mixture of gases. 
In 1774 Priestley discovered ammonia gas too, which he gave the name of alkaline air; and proved that mixed gases do not separate on standing, but remain uniformly distributed throughout the mass (diffusion of gases).

By passing electric sparks through ammonia gas, he observed that an inflammable gas was formed; and that phlogisticated air (the mephitic air of Rutherford and the nitrogen of Chaptal and later chemists) was evolved on heating ammonia with the calx of lead (lead oxide, $\mathrm{PbO}$ ). Although a brilliant experimentalist, "with rare quickness and perceptive powers," Priestley had not the genius of the philosopher; "he passed too rapidly from subject to subject even to notice the great truths which lay under the surface"; he left for others to interpret the results of his discoveries. The phlogistic doctrine was always in the way of this remarkable man; he never could free himself of its encumbrances, its wordy phraseology, and its false theory. He was blinded by Stahl's doctrine even to the end of his days. He only "looked at the results of his experiments through the fogs of his prejudices"; but his discoveries proved in the hands of Lavoisier the deathblow to phlogistic ideas. The conflict with error was ended and truth prevailed. His work represents the death of an old science and the birth of a new one. Such was the life of Joseph Priestley, and "le monde comme il va!" 


\section{LINNÆUS}

$$
1707-177^{8}
$$

TN the same year that England and Scotland were united into one kingdom, and two days after the Act of Union came into operation (3rd May 1707), there was born at Roëshult, Sweden, Carl Linnæus, the father of modern botany. He found biology a chaos, and he left it a cosmos. He was the first to popularize the study of botany in Europe by establishing the custom of using for a plant a second or specific name in addition to the generic name under which every specimen was then only known. Linnæus was destined to rescue botany from the degraded state to which Pliny and his imitators had reduced it. To this truly great man we owe the first attempt to remove the natural sciences from the control of those into whose hands they had fallen.

The origin of the name Linnæus is supposed to have had some connection with a lofty linden or lime tree which stood in the garden of the ancestral home.

It was intended that he should follow the same profession as his father-that of a Lutheran pastor; but 


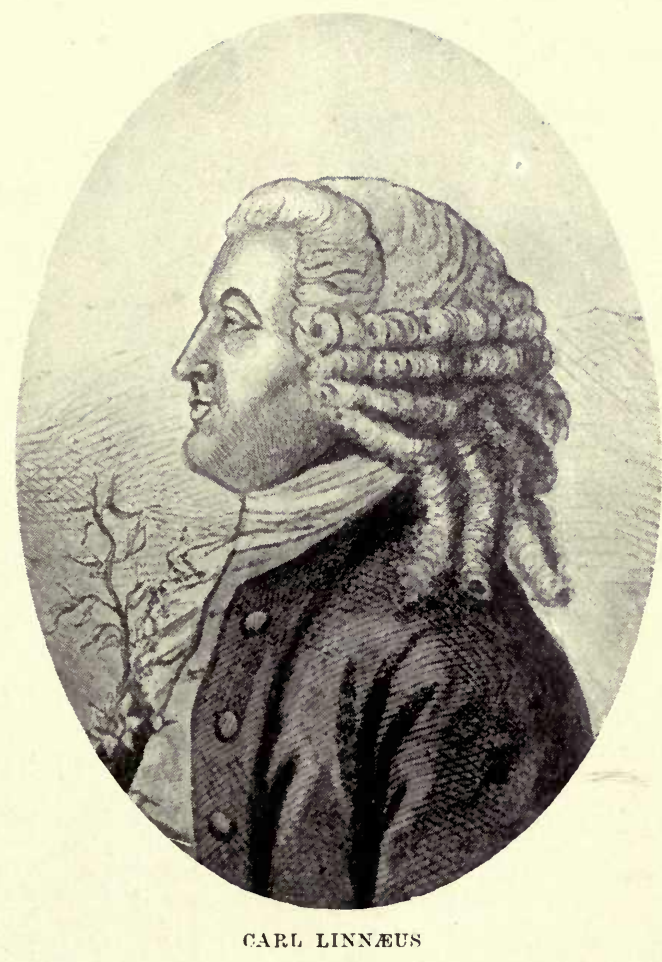

To face page 62.] 

surrounding the parental home was an extremely fine garden, and in its grounds young Linnæus laid the foundation of his subsequent studies. The father's garden was noted for being the finest and most variegated in the district, having as many as four hundred species of flowers. When quite young, Carl made himself familiar with the names of trees, plants, and flowers growing in the neighbourhood.

Until the age of ten Carl was educated by his father, but in 1717, when Charles XII. of Sweden and others were intriguing against the Brunswick dynasty in England, he was sent to his first school at Wexio. He had a fair elementary education, including Latin. The principal, or rector, of the school was fond of botany, and he took a special interest in Linnæus when he discovered that his new pupil knew all the names of the trees, plants, and flowers growing in the vicinity of the school. During his school days at Wexio, Linnæus greatly neglected his studies, and to such an extent that the tutors complained to his father. He was so enraptured with botany that he was compelled to confess to his father that he had no inclination whatever for the ministry. This was such a severe blow to the father that without further delay Carl was apprenticed to a bootmaker. However, this step caused other onlookers to think that young Linnæus would waste his time and talents as a bootmaker, so much so that Professor Rothmann (professor of medicine in 
Linnæus' college at Wexio) invited him to become a member of his household. This was accepted, and here Linnæus studied a little physic and a good deal of botany.

In 1727 he entered the University of Lund, and attended the lectures of Stobœus on physic and botany. Stobœus, noting the intelligence of the pupil, took him into his own home. Here he commenced the formation of a herbarium.

Afterwards Linnæus left Lund for the University of Upsala, and on an allowance of eight pounds a year the young man pursued his studies, wearing the cast-off clothes of other students, stopping up the holes in bis boots with paper, and frequently feeling the pangs of hunger. This was a most distressing time, but the youthful botanist struggled through it, cheering himself with knowledge he was daily gaining. This was the brave young spirit who consoled himself that "wisdom is better than rubies." How many others would have sunk under such an ordeal!

A benefactor at this period was Celsius, professor of divinity at Upsala, who was astonished at the extent of the knowledge of botany displayed by Linnæus. Celsius offered Linnæus board-residence free in his own home on condition that he helped the professor in his literary work. The professor was writing a work on the trees and plants mentioned in the Bible, and Linnæus was to help in the compilation of the work. It was in the library 
of Celsius Linnæus conceived the ground-plan of the system of classification by which he was to revolutionize botanical science. The system, since modified by the advance of knowledge, was based on external resemblances. The great work of Linnæus was constructive, not interpretative; and he lived in a period that may be called the renaissance of science.

Linnæus' work was a great step forward, and his system of classification was based on the reproductive organs (stamens and pistils) of plants. The number of species known to Linnæus in 1753 , when he published his Species Plantarum, amounted only to 7300 . The Linnæan division of plants is into twenty-four classes, depending on the number, position, relative proportion, and combination of the stamens; and the first eleven classes are distinguished solely by the number of the stamens, such as the monandria (one stamen), diandria (two stamens), triandra (three stamens), etc. The twelfth and thirteenth classes are characterized by the situation as well as number of the stamens; the fourteenth and fifteenth classes by the number and relative proportion of the stamens; from the sixteenth to the nineteenth classes, flowers are distinguished by the combination of the stamens with each other; the twenty-first, twenty-second, and twenty-third classes are characterized by the stamens and pistils being in separate flowers; and, finally, the twenty-fourth class, which comprises the Cryptogamia or flowerless plants- 
the oldest in the world's history. Each of the classes is subdivided into two or more orders. Such is an outline of the system of classification of Linnæus. The system brings together, for no other purpose than for convenience of reference, plants dissimilar in structure, habit, and properties. It is an "artificial system," such as Linnæus always intended it to be. It has been superseded by the "natural system" of De Candolle, which is based on various natural systems. Linnæus knew the value of a natural system of classification. He says : "Methodi naturalis fragmenta inquirenda sunt. Primum et ultimum hoc in botanicis desideratum est. Plantæ omnes utrimque affinitatem monstrant uti territorium in mappâ geographicâ. ... Methodus naturalis est ultimus finis botanicis. . . Naturalis character ab omni botanico teneatur oportet." He left a slight sketch of a natural system; but the limited knowledge of genera and species in his day would have rendered such a system of classification imperfect and useless. Not so, however, "his artificial system, which, still marked by the limits that he assigned, not only offers facilities for forming an acquaintance with the names of plants, but affords ready means of reference to any system in which plants are arranged according to their natural characters." Although superseded, the system of Linnæus is still useful as an index; and even the present natural system "cannot be regarded as being perfectly evolved." Linnæus established the binomial 
system of nomenclature, both in botany and zoology; and the grades of classification - class, order, genus, species, and variety-are his; and his great work, the Systema Naturx (1735), which passed through twelve editions in his lifetime, forms the starting-point of modern taxonomy.

Linnæus was a non-evolutionist; he firmly believed in the fixity of species. He was a synthetic genius who gathered all that was best in the work of the systematists from Cesalpino to Tournefort, and improved it. $\mathrm{He}$ was pre-eminently a describer and systematist, always classifying, co-ordinating, and subordinating.

In Linnæus' time the "best botanist was he who knew the most plants," however little of each; and even Linnæus himself was not abreast of the times in which he lived in matters of physiology. He contented himself in collecting, classifying, and naming; but as Jean Jacques Rousseau says, in his Dictionnaire de Botanique: "J'ai toujours cru qui on pourrait être un très grande botaniste sans connaître un seul plante par son nom." Times have altered since Linnæus' day, and now the student of botany masters thoroughly the principal types of the vegetable kingdom.

"The greatest and most lasting service which Linnæus rendered both to botany and zoology lies in the certainty and precision which he introduced into the art of describing": but for more than a hundred years after 
Linnæus there was little or no attempt to illuminate the science of botany from the standpoint of evolution. Advance, however, in this direction was commenced late in the Victorian reign.

In 1730 Linnæus was appointed Lecturer on Botany at Upsala. The vivacity and novelty of his lectures charmed his audiences, and he was greatly esteemed by the college authorities.

The Royal Academy of Sciences sent Linnæus to collect the flora and fauna of Lapland, and on 17th May, 1732 , at the age of twenty-five, he started on his ever. memorable journey with only ten pounds. Riding and walking were the modes of conveyance. Hardships and difficulties surrounded him ; rivers, bogs, forests, and want of food, however, did not stop his enthusiasm. "Nothing ventured, nothing won." Trees, shrubs, herbs, animals, mountains, etc., became the objects of his observation and attention. He used to rest his weary limbs in Laplanders' huts. It can be well imagined that the journey was a lonely and perilous one, when it is borne in mind that Lapland in those days comprised only thirty-two scattered villages.

Linnæus travelled over four thousand miles, and brought back to Sweden over a hundred plants previously unknown. He also studied the fauna and inhabitants of this inhospitable country; and in 1748 he published a book on his travels. 
On his return, Linnæus was elected a member of the Kongliga Svenska Vetenskaps-Academien (Stockholm), and at once recommenced his lectures; but the demon jealousy stepped in, by somebody complaining to the authorities of the college that it was against the charter of the University that lectures should be given by any but those who had obtained the full academical degree of $\mathrm{Ph.D}$. This was a critical and trying time; but, being supported by his students, he and they went on a visit to the mountainous districts of Sweden in order to study mineralogy and other sciences. At Fahlun he was introduced to Baron Reuterholm, himself a student of nature, and a man of great influence. He placed his two sons under Linnæus' care, and together with a few other young nobles, all went on a travelling tour.

On their return a little college was established under the patronage of the baron, and here Linnæus' lectures and the assaying of ores brought him friends as well as money.

In 1735 he set out for Holland, spent some time at Leyden, obtained his medical degree, visited Boerhaave, who gave him a letter of introduction to Burmann, then professor of botany at Amsterdam; and for some time he aided the professor in the description of the plants of Ceylon, which the latter had collected in the island. At this time Linnæus was introduced by Boerhaave to a wealthy patron named Cliffort, who spent large sums of 
money in acquiring treasures from all parts of the world, and, moreover, he was a man who was always imagining himself ill. Linnæus, who was qualified as a medical man, and was also a botanist of renown, was recommended as the very man for Cliffort. Linnæus was offered a home and an income of 1000 florins a year. Cliffort's gardens and hothouses were an El Dorado for Linnæus, and from this home he wrote and published his Fundamenta Botanica and Bibliotheca Botanica (1736). Both of these books established his fame, and attracted attention in all parts of Europe.

In the same year Linnæus visited England, interviewing Sir Hans Sloane, Philip Miller, and other botanists. After a short stay in England, he returned to Holland, and then commenced in earnest the system of classification which has made his name famous. During the year 1737 he published six works which diffused the revolution in botany from his Dutch home at Hartecamp throughout Europe. These works, several of which are classics, are replete in researches and philosophical and critical doctrines. In Genera Plantarum he described 935 species of plants, and the much discussed aphorism "that the characters do not give the genus, but the genus gives the characters."

Linnæus grasped the fundamental ideas of morphology, and he referred all the parts of the flower to leaves, arguing from the numerous transitions that the parts must 
be homologous. The homology of appendicular organs is suggested in the phrase "principium florum et foliorum idem est," and he developed his ideas in two memoirs, Prolepsis Plantarum (1760-63); only homologous parts, he said, can change into one another; "the liver cannot become the heart, nor the heart the stomach."

In 1751 Linnæus published his famous Philosophia Botanica-a work of the greatest importance; and in the previous year he constructed his floral clock-an arrangement of flowers opening and closing with regular periodicity; and he described the somnus plantarum, or the nocturnal changes of positions in flowers and leaves.

With all his ceaseless toil, impetuosity, and hardships, he was always enthusiastic in his studies and researches. In the words of Ovid: "Scribentem juvat ipse favor minuitque laborem; cumque suo crescens pectore fervet opus."

Owing to the financial difficulties of Cliffort, Linnæus was obliged to leave the beautiful and historic gardens of Hartecamp; but shortly afterwards he obtained employment in the botanical gardens at Leyden. While there he published two other works, which greatly enhanced his reputation.

At this period in his career, the Government of the Dutch Republic desired to send him on a botanical expedition to South Africa, and they promised to give him 
a professorship of botany in one of the universities, but the offer was declined.

Linnæus visited Leipzig, Saxony, Denmark, and Paris, and then returned to Stockholm. During his travels he met many distinguished men, and gained a vast amount of knowledge which proved useful in after years.

He reached Stockholm in September 1738, after three and a half years of fatiguing travels and laborious researches. It was only human that he expected honours and respect would be paid him. But this was not to be"a prophet has no honour in his own country." The Swedish authorities ridiculed his system and botanical researches. He was by far too great a revolutionist in botany even in his young days : and it is a terrible crime to upset old theories in botany as well as in other sciences. The great dignitaries in science must first be consulted, and this Linnæus did not do! Think of poor Hughes and wireless telegraphy-robbed of his invention by erroneous but weighty criticism. It was nothing short of a crime; "la critique est facile, mais l'art est difficile."

In the same year Linnæus practised as a physician, and was fortunate enough to attract attention of the Queen of Sweden and other notable people in the Swedish capital.

In 1739 he married Elizabeth Moræus, the daughter of a physician, and at the same time he was elected President of the Royal Academy. The next year he was appointed 
Professor of Anatomy and Physics in the University of Upsala, which has a great reputation at the present day. He also devoted many years to the development of the neglected botanical gardens at Upsala. He ultimately lectured on botany at the same university, and became its rector, and many of his students came from England, France, Germany, Russia and America. He also lectured on natural history and materia medica.

In 1768 Linnæus published the last edition of his Systema Naturæ, and in the preface he says :-

I have ranged through thick and shady forests of nature; I have to and fro found sharp and perplexing thorns; $I$ have, as much as possible, avoided them, but learned at the same time that foresight and attention do not always conciliate perfect and entire safety. I have therefore quietly borne the derision of grinning satyrs, and the jumps of monkeys upon my shoulders. I have entered the career and completed the course assigned by fate.

Concerning natural history, Linnæus published a description of the Swedish animals, birds, insects, minerals, etc., and he divided them into three kingdoms, and characterised them as follows :-

LAPIDES, corpora congesta, nec viva, nec sentientia.

Vegetabilia, corpora organisata et viva, non sentientia.

ANImalis, corpora organisata et viva et sentientia, sponteque se moventia.

Minerals are unorganized; plants are organized and live; and animals are organized, live, feel, and move spontaneously: and in the animal kingdom he had recognized six classes-mammals, birds, amphibians (including 
reptiles), fishes, insects, and worms. His work greatly reformed natural history in more ways than one.

Linnæus was the recipient of most of the honours awarded to men of science, and was a botanist of worldwide renown.

He died of apoplexy on 10th January 1778. He received a public funeral, and was buried in the Swedish capital.

Of posthumous honours erected to his memory, the most noted are the various Linnæan societies of the world. He was a man of great energy, untiring zeal and devotion to science, an enthusiast, a powerful lecturer, who communicated to his pupils the ideas and materials of his life's work, and withal a kind-hearted gentleman. 



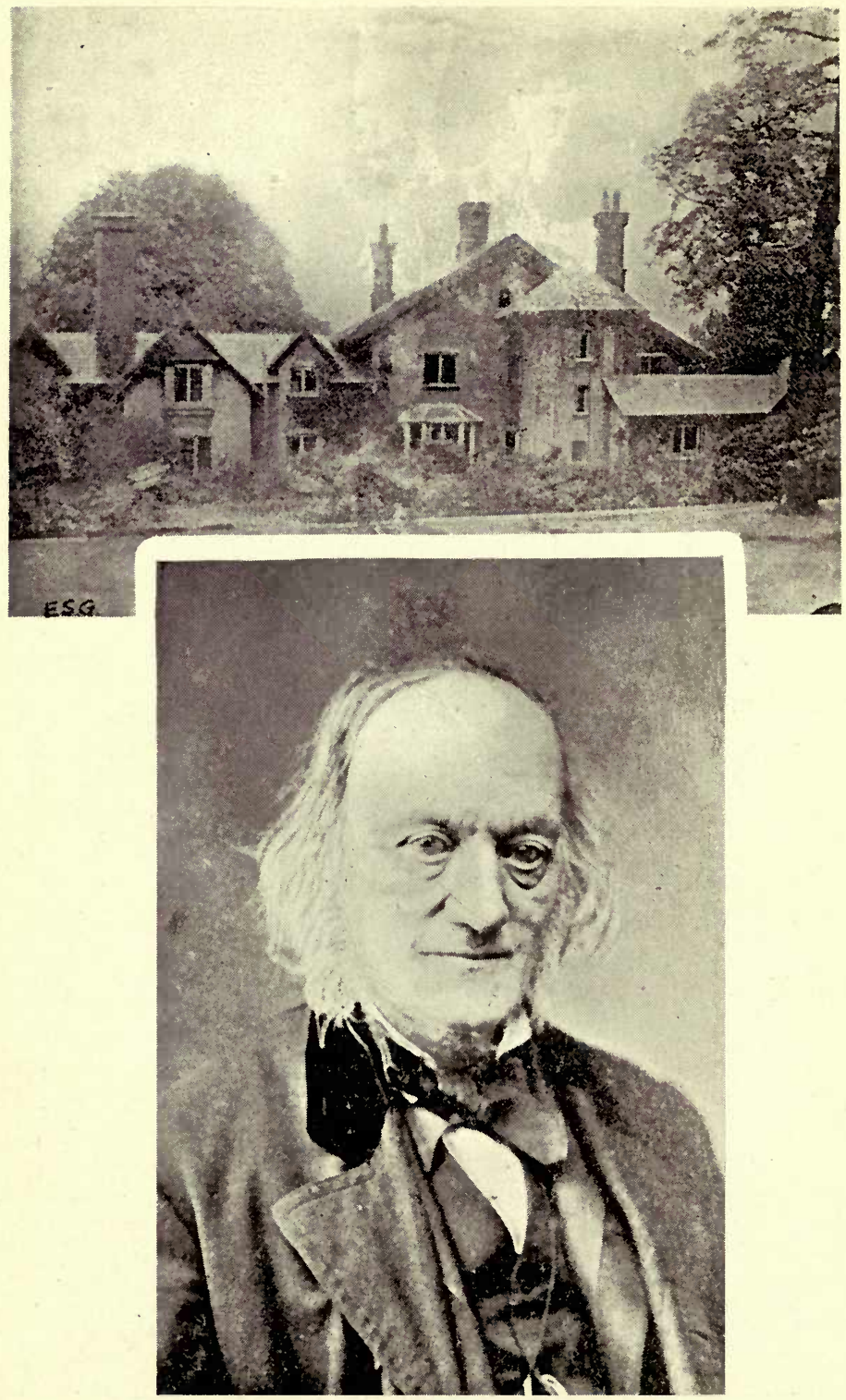

SIR RICHAlD OWEN, K.C.B., F. R.S.: AND SHEEN LODGE, RICHMOND PAlK (Photograph by Elliott \& F,y) 


\section{OWEN \\ 1 804-1 892}

"D OCTI non solum vivi atque præsentes studiosus dicendi erudiunt, atque docent; sed hoc etiam post mortem monimentis literarum assequuntur," wrote Cicero nearly two thousand years ago, and it is very true of Owen and others mentioned in the present volume.

At the time when Napoleon's invasion of England was completely organized, and only to be overthrown by the power of Nelson, there was born at Lancaster, on 20th July 1804, Richard Owen, destined to be the greatest comparative anatomist and palæontologist of the nineteenth century. Although an Englishman on his father's side, Owen's mother was of French extraction, belonging to a Huguenot family named Parrin, and at the age of six he went to the Lancaster Grammar School, but showed no signs during his schooldays of the bent of his future career. At the age of sixteen he was apprenticed to a surgeon and apothecary, and in 1824 proceeded to the Edinburgh University to study medicine; but the following year he came to London, where he joined the medical 
school of St Bartholomew's Hospital. During these days he was prosector to Abernethy, and in 1826 he obtained the Diploma of the Royal College of Surgeons. Having completed his medical studies, he began to practise as a medical man at 11 Cook's Court, Lincoln's Inn Fields; but from the beginning of his career he was much more interested in scientific pursuits than in strictly professional duties. In 1828, at the age of twenty-four, and knowing his great skill as a dissector, Owen was, at the suggestion of Abernethy, invited to act as assistant curator of the Hunterian collection in the Museum of the Royal College of Surgeons, of which Mr William Clift was curator; and in the same year he was appointed lecturer on comparative anatomy at St Bartholomew's Hospital. His duties at the Royal College were to catalogue the great collection of Hunter, whose manuscript had been lost. The collection meant the examination and description of no less than 3970 specimens. He was equal in every respect to this great task, as his subsequent genius proved.

In 1830 Cuvier visited England, and Owen made his personal acquaintance, and the following year visited Paris. Cuvier at this time was busy on his great work on fishes, which made a great impression on Owen, so much so that he attributed his subsequent work on palæontology to " the debt which he owed to Cuvier."

On 1st August 1831, during his visit to Paris, he went 
to the Theâtre Français, but did not stay to the end of the performance, stating that "the statue of Voltaire in the salle was worth all the money."

In 1832 Owen published his famous Memoir on the Pearly Nautilus, "which placed its author, at a bound, in the front rank of anatomical monographers," says the late Professor Huxley. "There is nothing better in the Mémoires sur les Mollusques; I would even venture to say nothing so good; . . . certainly in the sixty years that have elapsed since the publication of this remarkable monograph, it has not been excelled." The Pearly Nautilus (Nautilus pompilus) is interesting not only on its own account, but because of the large number of its fossil allies, and Owen won for himself an honourable place among naturalists by the masterly way in which he explained its structure and affinities. In his work he demonstrated for the first time the structure of the extinct group of cuttle-fishes to which the ammonites belonged, and to this his Memoir forms one of the classics of palæontology. It was translated into French by Milne Edwards, and into German by Oken.

Between 1831-34 Owen published thirty-seven papers, besides the catalogues of the Hunterian collection; these include papers on the anatomy and osteology of the orang-outang, beaver, suricate acouchy, Tibet bear, garmet, armadillo, seal, kangaroo, tapir, crocodile, stomapodous crustacea, ceropithecus, ariel toucan, flamingo, 


\section{BIOGRAPHIES OF SCIENTIFIC MEN}

hyrax, brachiopoda, cheetah, hornbill, lion, tiger, touraco, amphibia, etc.

In 1834 Owen was appointed Professor of Comparative Anatomy at St Bartholomew's Hospital, and elected F.R.S. On 20th July 1835, on the thirty-first anniversary of his birth, he married Caroline Clift, the daughter of the curator of the Museum of the Royal College of Surgeons.

In 1836 he was appointed Hunterian Professor at the Royal College of Surgeons, a position which he held for nineteen years. He also succeeded his father-in-law at the Royal College.

So much scientific work was entrusted to him that he had no time for practice as a medical man. Accordingly, he gradually withdrew from it, and devoted himself wholly to the labours in which he had already given evidence of an original and powerful genius. His industry was untiring, and in every publication he gave fresh proofs for penetrating insight and a capacity for far-reaching generalization.

Between 1833-40 he completed, in five volumes, the catalogue of the specimens in the Hunterian collection; and in 1853 appeared in two volumes the catalogue of the osteological specimens; in 1855, in three volumes, that of the fossil vertebrates and cephalopods. In 1840-45 he issued Odontography, a work in which he brought together a vast amount of observations on the structure of the teeth. Owen's lectures at the Royal College were 
published in book form in 1843 and in 1860-68-the former a volume on the invertebrata, and the latter, in three volumes, on the vertebrata; and in 1855 another series of lectures on the comparative anatomy and physiology of the invertebrate animals was published in book form, the volume occupying 689 pages of print, with 235 illustrations. In the concluding lecture Owen says :-

The invertebrated classes include the most numerous and diversified forms of the Animal Kingdom. At the very beginning of our inquiries into their vital powers and acts we are impressed with their important relations to the maintenance of life and organization on this planet, and their influence in purifying the sea and augmenting and enriching the land-relations of which the physiologist conversant only with the vertebrated animals must have remained ignorant.

These lectures were welcomed both in England and on the Continent; and in his work on the Archetype and Homologies of the Vertebrate Skeleton he made at the time a contribution of a high order to what may be termed the philosophy of natural history, showing how closely the bones, especially in the head, of vertebrate animals conform to a general type ; but the ideas expressed in this work limited his vision. This was a misfortune, as his theory has been altered by the subsequent work of embryologists.

In his work on the Archetype he dissented from the philosophy of Cuvier, and was inclined to that of Oken and Geoffroy Saint-Hilaire. In matters of morphological speculation Owen passed from the school of Cuvier into 
that of Cuvier's adversaries; but in matters of comparative anatomy and of palæontology his place is next to his master Cuvier, the founder of these sciences. In fact, Owen has been called "the British Cuvier," and lovingly by his friends "Old Bones," on account of his vast knowledge of osteology ; and concerning his book on The Anatomy and Physiology of the Vertebrates, the late Sir William Flower called it "the most encyclopædic work on the subject accomplished by any one individual since Cuvier's Leçons d'Anatomie Comparée."

Minute studies of the bones of living animals enabled Owen to reconstruct many extinct and fossil formsin this respect following in the footsteps of Cuvier. He reconstructed the Dinornis from a fragment of its femur; asserting that it belonged to a gigantic wingless bird, and, moreover, that it was a marrow bone like that of a mammal, and not a pneumatic one like those of birds; and, later, the whole skeleton of this bird was brought from New Zealand, and was exactly like the outline drawn (from a single bone) by Owen.

In 1849-84 he published his great work, The History of British Fossil Reptiles, and in 1846 a similar one on British Fossil Mammalia and Birds. His memoirs on the gigantic sloth (Mylodon robustus) discovered near Buenos Ayres, on the giant birds of New Zealand, on the Archropteryx macrura, the oldest known reptilian bird found in the Solenhofen stone of Bavaria, on the 
extinct reptiles of Great Britain, on the fossil belemnites from the Oxford clay, on the wading land bird Gastornis Parisiensis, etc., remain well-known classics. In 1877 he published two volumes, Researches on the Fossil Remains of the Extinct Mammals of Australia, with a Notice of the Extinct Marsupials of England, and in 1879 two volumes on the Extinct Wingless Birds of New Zealand; and even as late as 1889 he published monographs on fossil Reptilia and Cetacea. At the age of eighty-five we find Owen at work on his favourite subjects. This certainly upsets Oslerism, or "too old at forty"! And it should be borne in mind that the greatest philosopher of the nineteenth century, Herbert Spencer, did not commence writing his volumes on the Synthetic Philosophy until the age of forty.

In addition to the previously-mentioned researches, by his numerous memoirs on Mesozoic land reptiles, to which he gave the name of Dinosaurs, and a hundred or more other pieces of work, Owen did inestimable service to palæontology.

Owen excelled Cuvier in the accuracy of his work and in the generalizing spirit which he brought to bear upon his problems. Erroneous in some of his theories; but where is the worker who has not made faults? As Liebig said, "The man who never made a fault never worked."

The working out of the structural contrasts between 
the Artiodactyl and Perissodactyl Ungulata is representative of the best morphological work; and Owen rendered the greatest service to morphology in 1843 by his clear definition of analogy and homology - the former being illustrated by "a part or organ in one animal which has the same function as another part or organ in a different animal"; the latter being illustrated by "the same organ in different animals under every variety of form and function," i.e. organs of similar development and structure are homologous; organs of similar function are analogous. The further elaborations of homology, due to the doctrine of evolution, etc., have been worked out by Agassiz, Bronn, Haeckel, Mivart, Lankester, and others. Owen is the connecting-link between Cuvier and the present school of biologists. On the one hand, he was unappreciative of Darwinism, and on the other, "really believed in the derivation of species from one another." He will always be remembered, as long as natural history exists, for his practical work in comparative anatomy and palæontology ; but many of his philosophical ideas have been superseded by the work of modern biologists. It was unfortunate that Owen did not appreciate the work of Darwin and others. He was unable to accept the theory of the origin of species by natural selection, but his investigations did much to prepare the way for the general and rapid acceptance of Darwin's theory, since it was felt that there must be some strictly scientific explanation of the affinities by which 
he had shown vast groups of animals to be allied to one another.

Owen's palæontological work is of the highest order; and in work like his fossil mammals, birds, and reptiles, he excelled. The most characteristic of his faculties was a powerful scientific imagination. As the author wrote in one of his books, "the imagination is, after all, the most precious faculty with which a scientist can be equipped. It is a risky possession, it is true, for it leads him astray a hundred times for once that it conducts him to truth; but without it he has no chance at all of getting at the meaning of the facts he has learned or discovered." Professor H. E. Armstrong says : "It is justifiable to say that imagination plays an important part in chemistry; and that if too rigidly and narrowly interpreted, facts may become very misleading factors."

Fragments of bone which might be meaningless to less alert observers enabled Owen to divine the structure and present the images of whole groups of extinct animalsin this respect he was a disciple of Cuvier ; and Cuvier was Owen's model. Cuvier could not accept the doctrine of homology, or the likeness of corresponding organs in animals as regards structure and type, as, e.g., between the foreleg of a quadruped, the wing of a bird, and the arm of a man, which are of kindred origin, but modified through long and lateral descent for the work which they do. The influence of Cuvier's ideas on Owen was manifest through 
the career of the latter, arresting his development in certain directions. This is unfortunately shown in Owen's attitude towards Darwinism; he did not accept the doctrine of the mutability of species, the common descent of every animal and plant from formless or seemingly structureless masses of matter which, through an infinite series of changes, have become modified into the teeming forms that have flourished or that now flourish on this planet, which was satirically termed by Voltaire "le meilleur des mondes possible." But if Owen failed to appreciate the modern doctrine of evolution (he was fifty-five years old when Darwin's Origin of Species was issued), he had published nearly four hundred monographs, books, etc., and, like Priestley in another science, could not conscientiously alter his views. His attitude caused bitter resentment in certain quarters. He made, however, solid and permanently valuable contributions to natural history, and his "monographic work occupies a unique position."

His work on the anthropoid apes, on the Monotremes and Marsupials, on the Apteryx, the Great Auk and the Dodo, on Lepidosiren, on the Cephalopoda, on Limulus, on the Brachiopoda, and on Trichina spiralis, are all of the highest importance. Likewise his work on Darwin's extinct mammal of South America, Toxodon Platensis, "referable by its dentition to the Rodentia, but with affinities to the Pachydermata and the herbivorous Cetacea"; and his other memoirs on the extinct fauna 
of South America. As Huxley wrote: "I do not know where one is to look for contributions to palæontology more varied, more numerous, and, on the whole, more accurate, than those which Owen poured forth in rapid succession between 1837 and 1888."

Owen remarks in his Comparative Anatomy and Physiology of the Invertebrate Animals, 1855, p. 639, that physiology is dependent on comparative anatomy, but the idea is not applicable at the present day, as physiology is dependent on chemistry and physics. In later life he knew this, and greatly appreciated the work of others, as the following letters to the author bear evidence:-

4th February 1885. - I feel much indebted to you for the communication of the acceptable and interesting discovery of the renal organs of Astacus; and for the opportunity of connecting my name therewith as humble introducer of your refined analytic research to the Royal Society.

31st March 1885. . . . I shall receive with pleasure every research of yours.

18th May 1887.-I have read and studied your memoir "On the Nephridia and Liver of Patella vulgata" with instruction and gratification; the latter excited by the evidence of advance in the study of the functions of the organs of Molluscs as exemplified in the species selected. It cannot fail to excite similar applications of chemistry to the determination of function in other species as easily acquired for the purpose as the common limpet.

23rd May 1888. - Your valuable paper, "Further Researches on the Physiology of the Invertebrata," herewith returned, I have read carefully and profitably, but with effort, due to failing vitality. I fear you must enter me a worn-out scientist. What an expanse of workable ground your indefatigability opens to view! Long may you retain the powers exemplified in the manuscript I now return. With kindest regards and every good wish. 
In a letter of 14th March 1888 , to the author's wife, Owen wrote :-

Accept my grateful and respectful thanks for the copy of your interesting "Note on Degenerated Specimens of Tulipa sylvestris." If ladies with similar gifts of observation, and equal power of clear exposition, would as kindly bestow them, science would benefit more largely and rapidly than at present. I avail myself of this opportunity of also thanking your gifted husband for the valuable paper "On the Problematical Organs of the Invertebrata," which accompanied your gift.

In 1856 Owen was appointed Superintendent of the Department of Natural History in the British Museum, and his acceptance of this office necessitated the severance of his connection with the Royal College of Surgeons. The natural history collections at the British Museum were so extensive, and increasing so rapidly, that urgent demands for more space had frequently been made, and Owen took up the question with his usual enthusiasm. Ultimately the handsome building at South Kensington was erected, and from 1880 to 1884 Owen was engaged in superintending the removal of the collection. Owen could not but look with pride on the splendid result of his labours. It was the embodiment of what may be called one of the dreams of his life. Absorbing as his official duties often were, he did not permit them to stand in the way of his researches; and during the twenty-seven years of his connection with the British Museum he made numerous and valuable contributions to science.

Altogether he published nearly seven hundred memoirs, 
books, etc. He served on several public commissions, received a civil list pension, and all the honours and distinctions usually awarded to men of science. Among these may be mentioned that he was elected, on 25th April 1859 , one of the eight foreign associates of the Académie des Sciences; and in 1884 Queen Victoria conferred a K.C.B. He was also a chevalier of the orders: Pour le Mérite, Légion d'Honneur, Sts Maurice and Lazarus of Italy, the Rose of Brazil and Leopold of Belgium. Owen was also LL.D. of Edinburgh and Cambridge, and D.C.L. of Oxford Universities; and he received medals from the Royal, Linnean, and Geological Societies, and the Royal Colleges of Physicians and Surgeons. He was an honorary member of most of the learned academies and societies of the world. In fact, few men of science have ever received more numerous marks of distinction than Owen.

In 1852 Queen Victoria had shown her respect by granting him Sheen Lodge, Richmond Park ; and there he lived for the remainder of his long life. Owen resigned his official post at the Natural History Museum in 1883, at the age of seventy-nine. Although full of years, he had lost little of his mental vigour, and he continued to work in his retirement.

To talk to Sir Richard Owen was to be struck by the vastness of his knowledge, and "the noble dignity of his personal character was in every way worthy of his fame." To be in his company was to feel that one was in the 
presence of a genius. Nearly every one of his memoirs represents a large amount of laborious research, and in the aggregate they bear ample testimony to the soundness of that consensus of opinion which stamps Sir Richard Owen as the greatest palæontologist since Cuvier, and a comparative anatomist only second in the immensity and importance of his labours to Hunter himself.

Owen was a most interesting and charming character; was a prodigious and untiring worker; lived a long, active, public life; knew nearly everybody who was worth knowing; a friend of royalty, and to the earnest worker "a guide, philosopher, and friend."

Devoid of the least superstition, Owen told excellent ghost stories. These were famous and blood-curdling, and on many occasions he was particularly requested to narrate one or more of them. The stories were based on facts, which made them all the more interesting.

No man, not even Cuvier, has done so much as Owen to recreate the past, in visiting the "valley of dry bones" and informing these remains with the strange and weird life that endowed them; and in restoring in vivid outline that ancient world when huge "dragons of the prime" wallowed in the basins of the Thames and Seine, and when in a later age tigers, lions, hyænas and their kin contested with primitive man the supremacy of the sites where now London and Paris stand. It is pleasing to contemplate such pictures of the world's past. Who, outside scientific 
circles, would imagine that the elephant, rhinoceros, hippopotamus, bear, and other animals lived in England, France, Germany, and other parts of Europe?

Owen in his Palæontology states that "more true turtles have left their remains in the London clay at the mouth of the Thames than are known to exist in the world." What a difference from to-day!

Concerning Owen's attitude towards Darwinism, it may be stated that Herbert Spencer was no strict Darwinian, for he remained, like Haeckel and others, a firm believer in Lamarckism.

Early in 1890 Sir Richard Owen was seized with a paralytic stroke, from which he never entirely recovered, but lingered on until 18th December 1892, when he passed peacefully away.

Speaking of his own work, he wrote to the author on 26th December 1887, as follows :-

Your kindly greetings are always welcome; they brighten declining years with failing strength. But bright gleams, as such are, enliven an old worker who can look back with some satisfaction. The sun is now shining in upon my writing-table on a pile of friendly letters that must be acknowledged by yours very truly, Richard Owen.

Owen would have been buried in Westminster Abbey if it had not been his wish to be laid in the same grave as his wife (who died on 7 th May 1872). Both lie buried in Ham churchyard. 
At a public meeting on 21st January 1893, King Edward (then Prince of Wales) spoke of Owen as follows :-

The name of Sir Richard Owen must always go down to posterity as that of a great man-one who was eminent in the sciences of anatomy, zoology, and palæontology. . . . His geniality, his charm of manner to all those who knew him, will, I am sure, have left a deep and lasting impression. ... His method of teaching was earnest and clear in every respect, and it even gained a certain force from the hesitation in his manner.

A marble statue has been erected to the memory of Owen, and it adorns the hall of the Natural History Museum.

Sir Richard Owen rests from his labours, "and with his own right hand he carved his path from obscurity to a scientific throne. He stands among the sceptred immortals." 



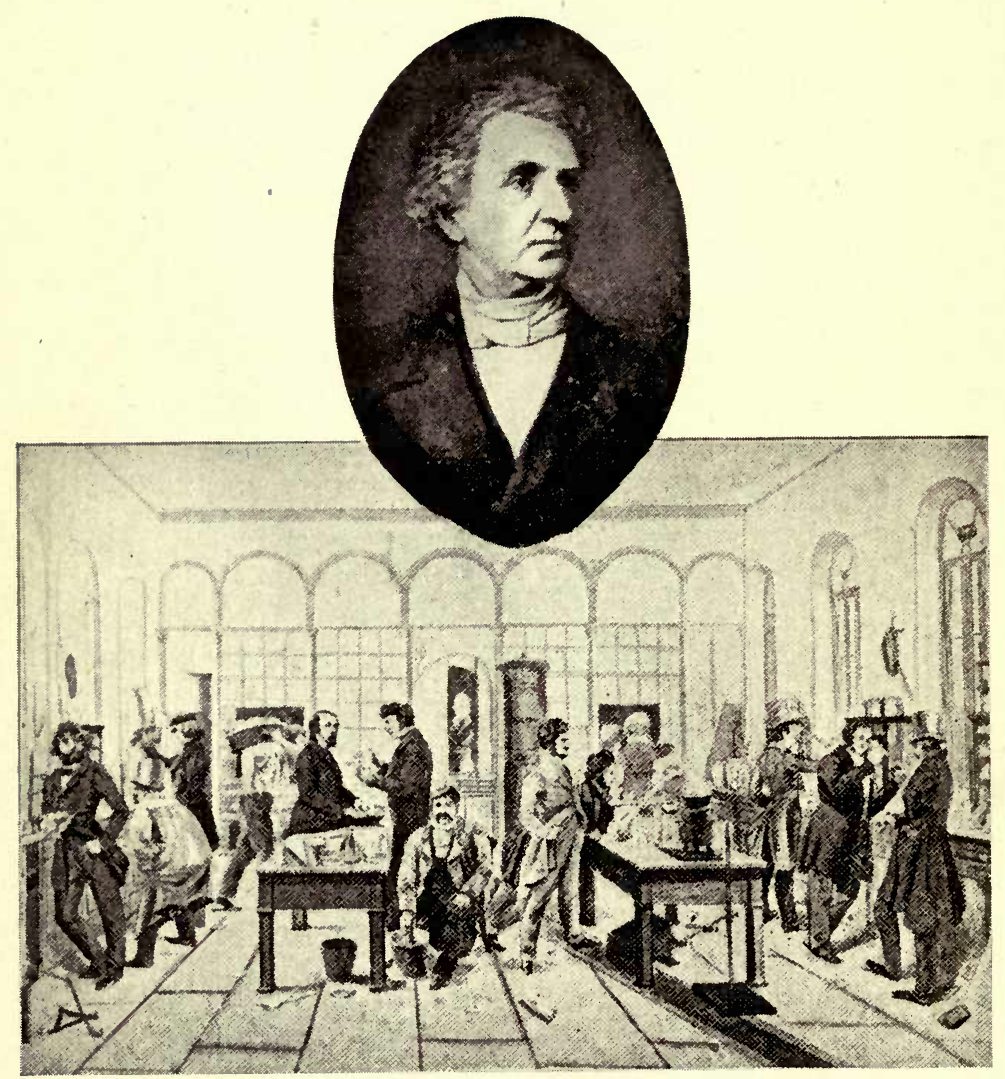

BARON GUSTUS VON LIEBIG AND THE GIESSEN LABORATORY IN 1840 


\section{LIEBIG$$
\text { I } 803-1873
$$

CERMANY'S great chemist was born at Darmstadt on 12th May 1803, the year that the Electorate of Hanover was seized and occupied by the army of Napoleon, and the violation of German territory by the seizure of the Duc d'Enghein at Ettenheim, and his subsequent execution.

Leibig's natural aptitude for experiments suggested the idea that he would be suitable for an apothecary; consequently, his father selected this as the profession for his son. He did not, however, long continue this work, and was sent to the University of Bonn, and entered as a student of medicine. He left Bonn, and graduated at Erlangen University at the age of eighteen. In Liebig's student days the German professors, unlike teachers in this country, enjoyed a perfect "Lehrfreiheit" (freedom in teaching), by which is meant the liberty of choosing the subjects which they treat in their lectures, and of expressing their views upon them freely. German professors used to read their lectures (some few delivered 
them): it may easily be imagined how fatal such a practice was to the graces of elocution. Goethe alludes to it in Faust:-

Doch euch des Schreibens ja befleisst

Als dictirt "euch der Heilig" Geist.

It may be mentioned that many parts of Faust are unintelligible to the reader who knows nothing of German university life.

During this period he studied natural science, and his progress was marked with such success that he was granted a pension or scholarship by the Grand Duke of Hesse-Darmstadt, which enabled him to continue his studies and researches. Liebig went to Paris in 1823. Having communicated a paper on fulminic acid to the Académie des Sciences, he was introduced to Alexander von Humboldt, Gay-Lussac, and other savants then living in the French capital. Liebig became a pupil in the laboratory of the famous chemist Gay-Lussac, discoverer of the law of volume. At the beginning of the nineteenth century there were only a few chemists in Germany, and this was the reason that he went to Paris.

In the same year that Liebig went to France, he began to perfect the method of organic or combustion analysis. The principle of the method is the one now used for determining the carbon, hydrogen, and oxygen in organic compounds. The compound is heated with copper oxide in a glass tube, and the carbon and hydrogen are 
oxidized to carbon dioxide and water, the former being absorbed by caustic potash, and the latter by calcium chloride. The method now in use differs from that of Liebig in only a few particulars, the principal of which is that gas has superseded charcoal.

In 1824 Liebig returned to Germany, having been appointed Professor of Chemistry in the University of Giessen -a seat of learning which he made famous throughout the world by means of his discoveries and teaching, and where he attracted students from all parts of Europe.

About this time Liebig gave special study to the cyanates, which were also being studied by Wöhler. The two young men became friends, recognized each others powers, and aided each other in scientific work, and many papers were published under their joint names. Liebig's researches were published in Poggendorff's Annalen; Liebig's Annalen der Chemie und Pharmacie; Handwörterbuch der reinen und angewandten Chemie; and Jahresbericht der Chemie: in all he published three hundred papers.

Liebig remained at Giessen for twenty-eight years, i.e., until 1852, when he accepted the chair of chemistry in the University of Munich. This was due to the influence of the King of Bavaria. His fame spread rapidly, and students filled his laboratory. Great enthusiasm was evinced at his lectures, and though not a fluent lecturer, the knowledge he imparted carried away his audience, 
for he taught living facts, not merely the dead ashes of science. The late Dr Hofmann, who was a pupil of Liebig, said of his master: "Nor was it so much the actual knowledge he imparted, as the wonderful manner in which he called forth the reflective powers of even the least gifted of his pupils. And what a boon was it, after having been stifled by an oppressive load of facts, to drink the pure breath of science such as flowed from Liebig's lips! What a delight, after having perhaps received from others a sack full of dry leaves, suddenly in Liebig's lectures to see the living, growing tree! We felt then, we feel still, and never while we live shall we forget, Liebig's marvellous influence over us; and if anything could be more astonishing than the amount of work he did with his own hands, it was probably the mountain of chemical toil which he got us to go through. Each word of his carried instruction, every intonation of his voice bespoke regard; his approval was a mark of honour, and of whatever else we might be proud, our greatest pride of all was having him for our master. Of our young winnings in the noble playground of philosophical honour, more than half were free gifts to us from Liebig; and to his generous nature no triumphs of his own brought more sincere delight than that which he took in seeing his pupils' success, and in assisting, while he watched, their upward struggle." Lucky was he who was under such a master. 
In 1840 (ever-memorable year), while at Giessen, Liebig published his famous and epoch-making work on agricultural chemistry, Die organische Chemie in ihrer Anwendung auf Agricultur und Physiologie. Although Davy, thirty years before, had published a work on Agricultural Chemistry, it was not until Liebig's book made its appearance that any great stride was made in the scientific principles of agriculture. This book is one of those few works which stand out from all others on the subjects of which they treat. It is undoubtedly the most important work on agriculture ever given to the world as the result of one man's researches and ideas. From the land of Kant, Fichte, Schelling, Schiller, and other philosophers, it is not surprising that we have such a farreaching and philosophic work as Liebig's Die organische Chemie given to us.

That an increase of solubility in bones and other phosphates would be attended by an increased productive power in the crop, was the idea of Liebig. He, in 1840 , recommended, in lieu of bones, the use of the substance long well known to chemists as the acid or superphosphate of lime, which is producible from bones and other phosphates by the action of oil of vitriol or sulphuric acid. Practice has since shown the great advantage of Liebig's suggestion.

The chief point of Liebig's famous book was to show that the humus of the soil is powerless to build up com- 
pletely the various tissues of plants. He taught that the carbonic acid of the atmosphere was the principal source of the carbon in plants; that their hydrogen came from water, their nitrogen from ammonia present in the air and soil. The sulphur, which is an ingredient in the protoplasm ("the basis of life") of living plants, comes solely from the sulphates and sulphur compounds contained in the soil ; and, finally, that the mineral ingredients found in the ashes of plants come from the soil in which they grow. ${ }^{1}$ Liebig further demonstrated that plants cannot live without these mineral ingredients, and that the humus of the soil is incapable of forming the sole nutrient material for plants.

Liebig says in his book (p. 174):

Although the quantity of humus in a soil may be increased to a certain degree by an artificial cultivation, still, in spite of this, there cannot be the smallest doubt that a soil must gradually lose those of its constituents which are removed in the seeds, roots, and leaves of the plants raised upon it. The fertility of a soil cannot remain unimpaired, unless we replace in it all those substances of which it has been deprived.

Liebig's theory was a revolutionary movement on the accepted ideas of scientific agriculture which dawned at the commencement of the nineteenth century.

$\mathrm{He}$ supported his theory by well-conducted experiments, showing that fields containing an excess of humus

1 See A. B. Griffiths' Treatise on Manures, and the Spanish translation of the same work by Eugenio Guallart, under the title of Abonos (1908). 
did not produce more than fields in which this ingredient was deficient. Although Liebig's theory of plant nutrition was essentially a mineral theory, yet he understood that organic matter (humus) decomposes in a soil, giving rise to carbonic acid and ammonia; and these gaseous bodies are also valuable plant foods. Liebig fully established the following important laws of husbandry:-

(1) A soil can be termed fertile only when it contains all the materials requisite for the nutrition of plants in the required quantity and in the proper form.

(2) With every crop a portion of these ingredients is removed. A part of this portion is again added from the inexhaustible store of the atmosphere; another part, however, is lost for ever if not replaced by man.

(3) The fertility of the soil remains unchanged if all the ingredients of a crop are given back to the land. Such a restitution is effected by manure.

(4) The manure produced in the course of husbandry is not sufficient to permanently maintain the fertility of a farm ; it lacks the constituents which are annually exported in the shape of grain, hay, milk, and live stock.

These laws of Liebig form the basis of modern scientific agriculture.

Liebig was the first to treat bones with "Schwefelsäure" or sulphuric acid in order to make the calcium phosphates soluble (superphosphate); and the late Sir John B. Lawes was the first to commence the manufacture of superphosphate on a large scale, both from bones and mineral phosphates.

From these early beginnings an enormous industry 
has been built up in every civilized country of the globe, but especially in England.

Liebig, like his own compatriot Heinrich Heine, could handle the weapon of satire with consummate skill, attacked England in the following words: "England is robbing all other countries of the conditions of their fertility. Already, in her eagerness for bones, she has turned up the battlefields of Leipzig and Waterloo, and of the Crimea; already from the catacombs of Sicily she has carried away the skeletons of many successive generations. Annually she removes from the shores of other countries to her own the manurial equivalent of three millions and a half of men, whom she takes from us the means of supporting, and squanders down her sewers to the sea. Like a vampire she hangs upon the neck of Europe, nay, of the entire world, and sucks the heartblood from nations without a thought of justice towards them, without a shadow of lasting advantage for herself."

His work revolutionized agriculture, and made a science of it. He says in his Familiar Letters on Chemistry that "chemistry leads man into the domain of those latent forces, whose power controls the whole material world, and on whose operation is dependent the production of the most important necessaries of life and society. . . No science like chemistry offers to man such a multitude of subjects for thought and reflection, and such stores 
of knowledge imbued with the charms of never-ending freshness; none is more calculated to awaken the talent for observation, or to sharpen the intellect in the strict method of applying proof for the establishment of a truth, or in the inquiry into the cause and effect of a phenomenon."

Concerning his great labours in the domain of agriculture, he says: "Does not chemistry promise that instead of seven grains we shall be enabled to raise eight or more on the same soil ?"

Great men work not only by their deeds, but also by their personal lives. Liebig laboured by the influence of his own example to destroy a prejudice which restrained most agriculturalists from devoting themselves to the study of scientific farming.

In 1845 the Grand Duke of Hesse-Darmstadt conferred upon him the title of baron, and in 1852, as already stated, he was appointed to the chair of chemistry in the University of Munich.

His researches were not only confined to scientific agriculture, but physiology, pathology, and organic chemistry owe much to his indefatigability. His influence in chemistry was great-being one of the world's most famous chemists-and to his numerous pupils he was their "guide, philosopher, and friend." He satirized the work of other leading men, as the following remark bears evidence. In 1867 Liebig being asked by Dumas 
why he had abandoned organic chemistry, replied that "now, with the theory of substitution as a foundation, the edifice may be built up by workmen: masters are no longer needed."

Although he had his own views on most subjects, he was always open to correction. He said : "In the history of the evolution of any science, the researches of a given period of time furnish certain general relations which every moment are changed and improved upon by new discoveries. Thus an endeavour arises to arrange the new-discovered facts and to find the common bond by which they are linked together."

Liebig's definition of a compound radicle holds good to this day, although his definition of organic chemistry -as the study of the compound radicles-has been superseded by that of Schorlemmer, who defines organic chemistry as that branch of the science which treats of "the hydrocarbons and their derivatives."

Liebig predicted the organic ammonias, and discovered chloroform-the invaluable liquid which was first introduced into medicine by Sir James Simpson in 1848. He also discovered chloral and aldehyde. Liebig established the molecular formula of citric acid, and proved that it was tribasic; and in the year 1838 appeared his classical memoir on the constitution of organic acids, showing that the doctrine of basicity could be applied to them as well as to the acids of inorganic chemistry. 
It was Liebig who actually discovered bromine froto the liquor of the salt works. He saturated the liquor with chlorine, and by distillation obtained a quantity of a dark red liquid. He thought it was the chloride of iodine, but did not examine it. It was on the shelf in his laboratory, and there it remained for several months. In 1826, Balard, of Montpellier, discovered bromine, and in Liebig's laboratory this very same bromine was labelled "liquid chloride of iodine." $\mathrm{He}$ was only twenty-three when the incident occurred, but he resolved in future never to take anything for granted, or to accept theories which were not well supported by trustworthy experiments.

Liebig was a man of untiring labour, always at work, early and late, and his discoveries and philosophy have proved of the highest importance to mankind. His mind was open to correction; he once said that "there is no harm in a man committing mistakes, but great harm indeed in his committing none, for he is sure not to have worked."

Liebig's books on Animal Chemistry (1842), Researches on the Chemistry of Food (1847), The Natural Laws of Husbandry (1862), etc., have been translated into most of the languages of Europe.

Liebig often visited England, and attended several meetings of the British Association. In 1837 he was requested by the Association to draw up a report on the 
progress of organic chemistry, which he did; and in the same year, speaking of radicles, he said that "in mineral chemistry the radicles are simple; in organic chemistry the radicles are compound-voilà toute la différence."

Liebig was not content to merely formulate generalizations and leave the details of work to others; he brought his philosophy down to the level of the average mind; and by inventing the extractum carnis Liebigis, or Liebig's Extract of Meat, he gave to the world an article of vast importance to the invalid and housewife.

He received most of the honours that are usually awarded to men of science, such as the Copley medal of the Royal Society, and the associateship of the Académie des Sciences (l'Institut de France). He will ever be remembered for his work in agricultural chemistry and combustion analysis, both of which are unique in the annals of chemistry.

Two years after the Franco-Prussian War and the reconstitution of the German Empire, Baron Justus von Liebig died on 18th April 1873, at the age of sixty-nine years, leaving the products of his genius to aid the progress of humanity.

He was "honoured and respected by every student of science, and loved by each of the band of ardent natures whom he had trained and set forth to battle for the good of their race." As a teacher he was unsurpassed, and a brave array of great thinkers sprang up as if by magic, 
due to his great enthusiasm and influence on the minds of men.

Lives of great men all remind us

We can make our lives sublime,

And, departing, leave behind us

Footprints on the sands of time.

Longfellow.

Concerning Liebig's great power as a teacher, we may say with Cicero: "Quod munus reipublicæ afferre majus meliusve possumus quam si docemus atque erudimus juventutem." 


\section{LYELL \\ I 797- 1875}

$\mathrm{A}^{\mathrm{T}}$ the time when England won the great naval seaSpanish, French, and Dutch fleets were defeated, there was born on 14th November 1797, Charles Lyell, the future geologist of Great Britain.

He was the eldest son of Charles Lyell of Kinnordy, in Forfarshire. His father was an extensive landed proprietor, and a man of scientific and literary pursuits. Lyell père was an ardent botanist and translator of Dante's Vita Nuova and Convito; and Lyell fils had a liking for entomology, which he cultivated to his heart's content in the New Forest, his parents having removed to that neighbourhood soon after his birth.

He was educated at Midhurst and at Exeter College, Oxford, where he graduated in 1819-the same year that saw the birth of Queen Victoria. At the university he had the good fortune to attend the lectures of Dr William Buckland, the founder of English geology, and which 


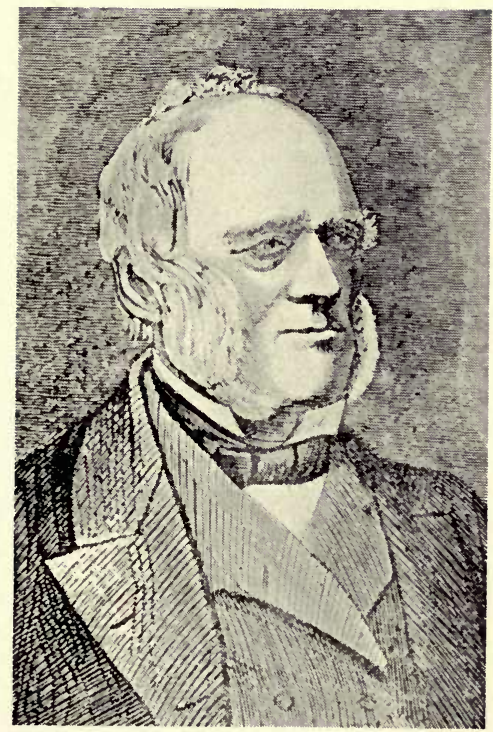

SIR CHARLES LYELL, BART. 

greatly inspired him to make "the study of the rocks" his life's work. In 1821 Lyell came to London, entered Lincoln's Inn, and in 1825 was called to the bar. Having practised as a barrister for two years, he finally resolved to follow the life of a man of science. His first contribution to scientific literature was "On the Marls of Forfarshire," in 1822. In the following year he visited France, was introduced to Cuvier, Humboldt, and other distinguished men, and in 1824 accompanied Buckland on a geological tour in Scotland, and thereby laid the foundation of his subsequent scientific career.

Having been appointed Professor of Geology at King's College, London, Lyell was elected F.R.S. in 1826. Between the years 1830-33 he published his famous work, The Principles of Geology. This work is the masterpiece of the great geologist, and is a classic in scientific literature : encyclopædic in its scope, and exhaustive in its treatment, it may be looked upon with pride, not only as a representative of English science, but as without a rival of its kind anywhere.

The Principles contain an elaborate criticism of Lamarck's views. Lamarck, poor, neglected, and blind in old age, died in 1829, and was attacked by Lyell, who refuted the former's ideas concerning the origin of species; but this adverse criticism was the means of giving Herbert Spencer "a decided leaning to them "- "a partial accept- 
ance of Lamarck's view." Nevertheless, The Principles of Geology was " a work destined to assist in paving the way for the removal of one difficulty attending the solution of the theory of the origin of species, namely, the vast period of time for the life-history of the globe which that theory demands." Although at the time, when the book was first published, its author had other aims in view than those to which it contributed. Charles Darwin says, in the ninth chapter of The Origin of Species: "For my part, following out Lyell's metaphor, I look at the geological record as a history of the world imperfectly kept, and written in a changing dialect; of this history we possess the last volume alone, relating only to two or three countries. Of this volume only here and there a short chapter has been preserved, and of each page only here and there a few lines. Each word of the slowly-changing language, more or less different in the successive chapters, may represent the forms of life which are entombed in our consecutive formations, and which falsely appear to have been abruptly introduced."

In The Principles of Geology Lyell followed the doctrines of geological uniformity and continuity of action laid down by Hutton, Buffon, and William Smith, and proved that the various formations of the earth's crust were produced by the very same agencies that are still active in the world. These views were assailed from all quarters as trifling and insignificant-trifling in attempting 
to explain the formation of valleys and mountain ranges, etc.; but a few, and only a few, read between the lines, and saw that

The world is wide-these things are small:

They may be nothing, but they are all.

Nevertheless, Lyell, despite all opposition, devoted his life to pursuance of the doctrine that the rocks, mountains, valleys, seas, rivers, etc., were produced in past time by "causes now in operation," still going on " unresting" and "unhasting."

The Principles of Geology was a work which revolutionized geology; theories of cataclysms and catastrophes were swept away by the master-mind of Lyell. What a stupendous service was rendered to science-progress free from prejudice; well might his bones rest in Westminster Abbey.

"Geology," Lyell defines, "is the science which investigates the successive changes that have taken place in the organic and inorganic kingdoms of nature; it inquires into the causes of these changes, and the influence which they have exerted in modifying the surface and external surface of our planet. By these researches into the state of the earth and its inhabitants at former periods we acquire a more perfect knowledge of its present condition, and more comprehensive views concerning the laws now governing its animate and inanimate productions." 
$\mathrm{He}$ classified rocks, according to their origin, into four great divisions-aqueous, volcanic, plutonic, and metamorphic rocks. These divisions have reference to their origin - the agencies at work in rock formation.

Lyell was always making geological tours in order to gain information and further evidence to support the great idea of his life. In 1828 he, in company with Murchison, went to France, and the observations then made gave rise to two papers: "On the Volcanic District of Auvergne," and "On the Tertiary Formations of Aix-enProvence." In the former paper he confutes Von Buch's idea of "elevation craters," and states that cones owe their "origin to a series of eruptions," . . . " where the cavity is present, it has probably been due to one or more great explosions similar to that which destroyed a great part of ancient Vesuvius in the time of Pliny. Similar paroxysmal catastrophes have caused in historical times the truncation on a grand scale of some large cones in Java and elsewhere."

Due to studying Bonelli's collection of Tertiary shells at Turin, and the marine fossils of the Tertiary rocks of Sicily and Ischia, Lyell divided the Tertiaries into the Eocene, Miocene, and Pliocene formations.

In 1832 Lyell married Mary, the eldest daughter of Leonard Horner. She was an accomplished linguist, and her husband's companion through life, sharing his labours, and "who braved with him the dangers and 
difficulties of travel, no matter how rough." It has been said of her that "had she not been part of him, she would herself have been better known to fame."

Lyell published, in 1838, the Elements of Geology; but his books and papers are all either more or less expansions of the epoch-making Principles, or observations which extend and confirm the theories enunciated in it. He followed the ideas of Hutton, who said: "I take things such as I find them at present, and from these I reason with regard to that which must have been."

In 1834 he published two papers, "On the Proofs of the Gradual Rising of the Land in Certain Parts of Sweden," and "On the Cretaceous and Tertiary Strata of Zeeland and Moën," after paying a visit to Sweden and Denmark. Three years later he again visited Scandinavia; and in 1841 he spent a year in the United States and Canada, repeating the visit in 1845 . These travels gave rise to numerous geological papers, and to two books: Travels in North America, published in 1845; and A Second $V i s i t$ to the United States, in 1849. In these works he describes the American character and institutions, and his adventures in the land of liberty.

The same year that Louis Philippe abdicated, and the kingdom of Poland was absorbed in Russia, Germany, and Austria, Lyell was knighted, and sixteen years later, namely, in 1864, he received a baronetcy, but dying without 
issue, his baronetcy, like that bestowed on his confrère Murchison, became extinct.

In 1858, one year before the publication of Darwin's famous book, The Origin of Species, he revisited Sicily in order to make observations upon the structure of Etna, and, as already stated, he refuted the theory of "Elevation Craters"- the "cupolas" of the German geologists. This theory stated that all great volcanoes were formed of masses originally deposited in a horizontal position, and subsequently blown up into a conical form. Lyell proved that in the case of Etna, during the earlier periods of its history, the piling up of materials went on around a centre which is now situated at a distance of nearly four miles from the present focus of eruption. His "Memoir on the Lavas and Mode of Origin of Mount Etna" is to be found in the Philosophical Transactions for 1858 .

In 1863 Sir Charles Lyell published his famous work on The Geological Evidences of the Antiquity of Man, with Remarks on Theories of the Origin of Species by Variation. In this marvellous book a vast amount of details and research are brought forward in regard to prehistoric man, and the times in which he lived. Concerning the Pleistocene alluvial deposits in many European valleys, there were found "works of art of the ages of iron and bronze, and of the later or Neolithic stone period. In the more ancient or Palæolithic gravels there have been found in 
several valleys in France and England stone implements of a rude type, showing that man co-existed with the mammoth and other extinct quadrupeds." "The alluvial and marine deposits of the Palæolithic age, the earliest to which any vestiges of man have yet been traced back, belong to a time when the physical geography of Europe differed in a marked degree from that now prevailing. ... Among the general of extinct quadrupeds most frequently met with in England, France, Germany, and other parts of Europe, are the elephant, rhinoceros, hippopotamus, horse, great Irish deer, bear, tiger, and hyæna.

The first portion of The Antiquity of Man is devoted to the "geological memorials of man"-his bones, implements, etc., proving that he was an inventive animal even in these early ages of the world; the second portion is on the glacial epoch, and bears strictly on the question whether primitive man is pre-glacial or post-glacial; and the third and final portion treats of the "origin of species," and "man's place in nature."

The book altered public opinion as to the duration of the human race upon the earth. In the same work, Lyell threw in his lot with Darwin on the origin of species by natural selection, although with reservations, for "he never wholly accepted the inclusion of man."

In 1871 Lyell published his Student's Elements of Geology, and in this and his other books, which have 
passed through many editions, the gist of his doctrines and discoveries may be found.

During the seventy-eight years that he lived on this mundane sphere, he published seventy-six memoirsor nearly one every year of his existence. Lyell was a philosopher in every respect, sound to the core, free from bias, a respecter of other men's opinions, although a critic where criticism was thought to be just. He was "the most philosophical and influential geologist that ever lived, and one of the very best of men."

Sir Charles Lyell received almost every honour which usually falls to scientific men from his own and other countries. He was a member of nearly every academy and scientific society in the world, and many degrees and medals were awarded to him.

During the later years of his life his sight, always weak, failed him altogether. Although very feeble, the actual cause of his death was a fall down the stairs of his house, 75 Harley Street, London, W. This took place on 22nd February 1875.

During his long life, as the late Dean Stanley said, "it was to him a solemn religious duty to be incessantly learning, constantly growing, fearlessly correcting his own mistakes, always ready to receive and reproduce from others that which he had not in himself."

Sir Charles Lyell was buried in the nave of Westminster Abbey, where the well-known gravestone of fossil marble 
from Derbyshire (and twenty paces from the grave of Darwin) bears a lengthy inscription detailing his labours. Near the grave there is a marble bust to his memory.

As an epoch-maker, Sir Charles Lyell had to pass through the fire of hostile criticism. He knew, however, that he had discovered truth, as interpreted by Nature's book - the rocks - and that he could with equanimity listen to the babble of little minds. Moreover, he was entirely free from vanity, egotism, and jealousy-in fact, a true philosopher and gentleman, with kind feelings and appreciation for the work of others. Science owes much to Lyell, and for centuries to come, yea for all time, he will receive the homage of posterity. 


\section{DALTON \\ I 766-I 844}

TOHN DALTON, the founder of the chemical atomic theory, was born at Eaglesfield, Cumberland, on 5th September 1766. He was a Quaker, and the son of Joseph and Deborah Dalton; and he attended the village schools until he was eleven years of age. He was a steadygoing, thoughtful, and industrious boy.

In 1778 he began to teach in a school at Eaglesfield, but had great trouble to maintain discipline owing to some of his pupils being as old as himself. Disputes were often settled by exhibitions of physical force displayed in the neighbouring churchyard. Three years later he gave up the school, and went as assistant to his cousin, George Bewley, at Kendal, which position he occupied four years. At the end of this time Bewley retired, and the school was continued by the brothers, John and Joseph Dalton, but as teachers they were not popular owing to their uncouth manners.

After leaving Kendal, Dalton went to Manchester as a science tutor to the Manchester New College then exist- 


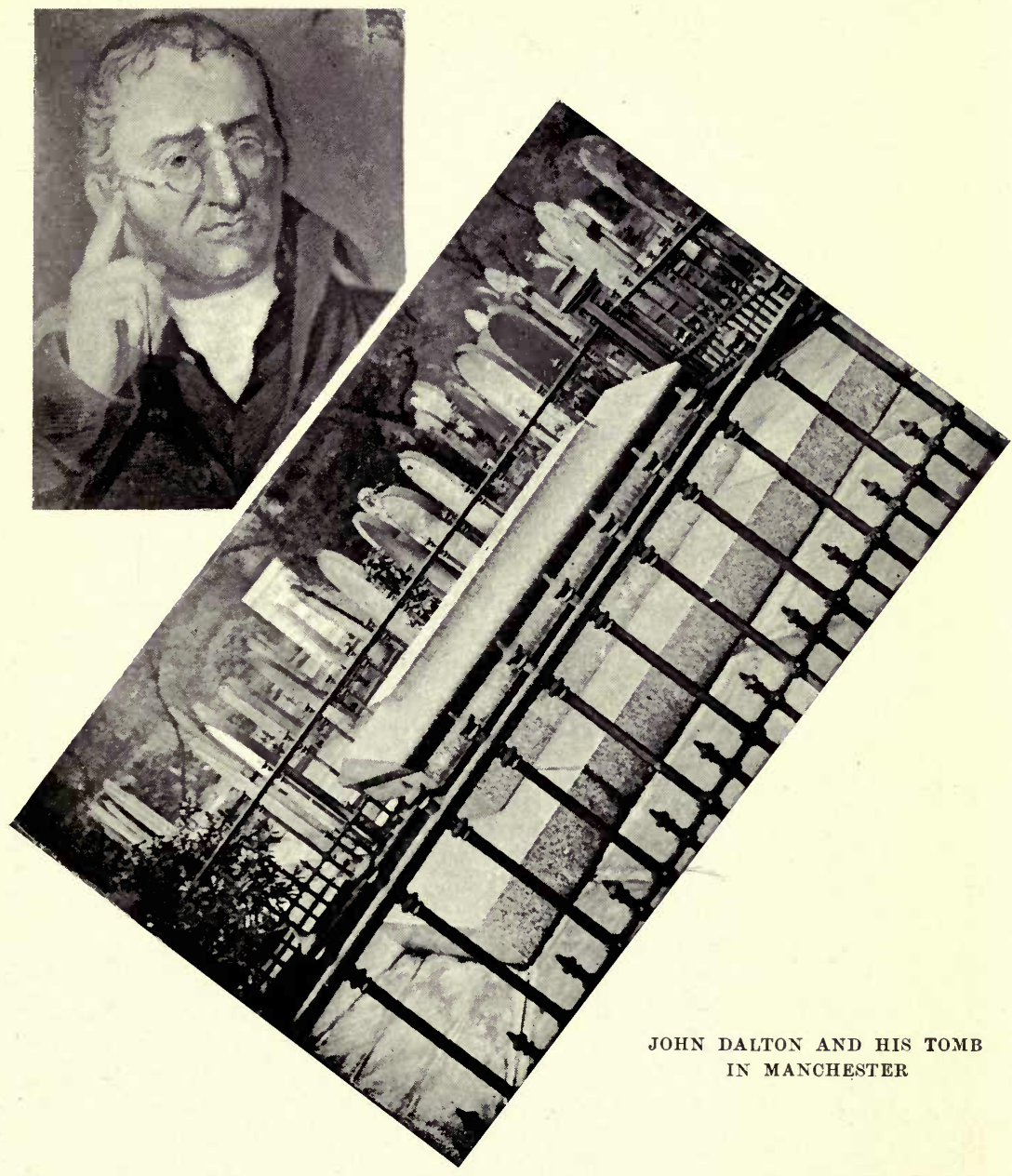

To face page 114.] 

ing in the city, and afterwards as a private tutor of science and mathematics. "As a schoolmaster he began life, as a schoolmaster he ended it," but such routine work was not the sole occupation of his mind-far from it.

His scientific Observations upon the Weather were begun on 24th March 1787, and continued until the day before his death (i.e. for over half a century).

In 1794 Dalton was elected a member of the Literary and Philosophical Society of Manchester, and for fifty years he spent his time, in a room of the Society's house in George Street, in teaching, writing, and studying.

His first paper, in 1794, was "Extraordinary Facts relating to the Vision of Colours." Dalton had a defective colour sense, which was amusingly confirmed by the presentation to his mother of a pair of scarlet silk stockings when he was under the impression that they were drab. On another occasion, when selecting cloth for a new suit of clothes, he requested a drab material; a piece caught his eye, and he remarked that it was just what he required, but the tailor informed him it was scarlet cloth for hunting coats.

About this time he published a book on Meteorological Observations and Essays, recording the connection between the aurora borealis and electricity, on the dew-point, thermometers, barometers, etc.

In 1799 he proved that aqueous vapour exists in the atmosphere. In 1800 he published a paper on the con- 
ducting power of water for heat; and in 1801 appeared his Constitution of Mixed Gases, wherein he proved "the total pressure of a mixture of two gases on the walls of the containing ressel is equal to the sum of the pressures of each gas; in other words, that if one gas is removed the pressure now exerted by the remaining gas is exactly the same as was exerted by that gas in the original mixture."

It may be mentioned that among Dalton's pupils was the celebrated James Prescott Joule (of the "mechanical equivalent of heat" and the "conservation of energy" fame). Both tutor and pupil are in the first rank of scientific investigators, and hence Manchester has the perhaps unique distinction of having been the bome of two of the greatest natural philosophers who ever lived.

John Dalton, the Quaker philosopher, was the founder of the atomic theory, and this great generalization is one of the foundation-stones of modern chemistry.

Leucippus appears to have been the first to grasp the idea that matter is composed of ultimate particles or atoms. Democritus of Abdera (born 460 B.c.) developed the atomic theory of Leucippus, and stated that atoms were impenetrable and indivisible. Epicurus (born 340 B.c.) gave mobility to the atoms, and otherwise greatly improved the atomic theory of the Greek philosophers. According to these sages "the world is composed of an innumerable quantity of atoms, mobile, 
infinitely small, and distant from each other." These ideas were nothing more than a brilliant speculation. The atomic theory remained a speculation for over two thousand years, until Dalton discovered the law of mutiple proportions, and deduced therefrom that matter is composed of atoms having weights, and that the atoms are of various kinds. When atoms of the same kind come into juxtaposition, elements are formed, such as oxygen, hydrogen, chlorine, etc. Compounds are formed from the juxtaposition of different kinds of atoms, such as water, ammonia, carbon dioxide, etc.

This is not all: to Dalton's law of multiple proportions, the law of Avogadro is adjoined. The latter law establishes that all gases, temperature and pressure being equal, have the same elastic force. As this force is probably due to the shock of atoms or groups of atoms (molecules) on the sides of vessels which contain the gases, it is evident that equal volumes of all elementary gases contain the same number of molecules or atoms. And, finally, Dulong and Petit proved that the atoms of the elements all possess the same specific heat. All these laws, which were the result of observation and experiment in the early part of the nineteenth century, have converted into a scientific theory the ideas of the philosophers of ancient Greece.

Dalton's laboratory was in the lower rooms of the Manchester Literary and Philosophical Society, and 
"was never remarkable for neatness. ... His bottles were of every shape, size, and colour, and his apparatus was of the most humble and inexpensive description. He often performed experiments at the cost of a few shillings on which others would spend as many pounds." What wonderful results were obtained with such meagre appliances! It may be asked whether the laboratories of Lavoisier, Priestley, and Dalton, with their meagre appliances, produced better work than the luxuriouslyfitted laboratories of to-day. The question is not easily answered. It must, however, have been simply delightful to have worked under Lavoisier, Priestley, or Dalton, each a genius and pioneer in the early days of modern chemistry. Lavoisier and Dalton were the architects of a new chemistry - a chemistry which has stood the test of time, and is of the greatest value to all nations-in fact, the "wealth of nations."

In 1803 Dalton published a paper "On the Absorption of Gases by Water and other Liquids." This memoir had an important bearing on Henry's law discovered in the same year.

The first account of Dalton's famous atomic theory appeared in Thomson's Chemistry in 1807, he having told Thomson of his experiments and deductions. In 1808 Dalton published his New System of Chemical Philosophy, in which the theory of atoms was fully expounded; and he described experiments directed towards the estimation 
of the relative weights of atoms. The numbers he obtained as representing the atomic weights were in many cases erroneous; but they were rectified by the work of Berzelius (1779-1848), and even now these constants of nature are subject to frequent revision. It was, however, to the genius of Dalton that the atomic weights of the elements were first comprehended.

Since Dalton's time, the sizes, intervals, and velocities of atoms have been ascertained. These problems have been solved by Clausius, Kelvin, Clerk Maxwell, and others from various sides: "from a comparison with the wave-lengths of light, with the tenuity of the thinnest films of soap-bubbles just before they burst, and from the kinetic theory of gases, involving the dimensions, paths, and velocities of elastic bodies, constantly colliding, and by their impacts producing the resulting pressure on the confining surface." For instance, one cubic centimetre of air contains twenty-one trillions of molecules; the average distance between each molecule equals ninety-five millionths of a millimetre; the average velocity of each molecule is four hundred and forty-seven metres per second; and the average number of impacts received by each molecule is four thousand seven hundred millions per second.

In 1865 Loschmidt of Vienna, twenty-one years after Dalton's death, calculated that the diameter of an atom of oxygen was the one-ten-millionth of a centimetre; 
and Kelvin came to the conclusion that the distance between the centres of contiguous molecules is less than the one-five-millionth and greater than one-thousandmillionth of a centimetre.

All this work has been the outcome of Dalton's atomic theory. Sir George Darwin says that "within the last few years the electrical researches of Lenard, Röntgen, Becquerel, the Curies, Larmor, Thomson, and a host of others have shown that the atom is not indivisible (as Dalton assumed), and a flood of light has been thrown thereby on the ultimate constitution of matter. Among all these fertile investigators it seems that J. J. Thomson stands pre-eminent, because it is practically through him that we are to-day in a better position for picturing the structure of an atom than was ever the case before. It has been shown that the atom really consists of large numbers of component parts. By various converging lines of experiment it has been proved that the simplest of all atoms, namely, hydrogen consists of about three hundred separate parts; while the number of parts in the atom of the denser metals must be counted by tens of thousands. These separate parts of the atom have been called corpuscles or electrons, and may be described as particles of negative electricity."

As Professor Rutherford says: "It is not true that the discoveries of the last ten years had weakened the atomic theory. On the contrary, they had enormously strength- 
ened it." It is an error to suppose that recent research has removed Dalton's atomic theory or rendered it obsolete. We now know that Dalton's atoms are not atoms, but it is still true that "elements combine in constant proportions by weight." In the words of Sir George Darwin: "The vast edifice of modern chemistry has been built with atomic bricks." From the later work of to-day we know that the atom is not the ultimate form of matter. There are corpuscles and ions inconceivably smaller; but, says Professor A. Smithells, "few will deny that the atomic theory stands to-day an indispensable instrument for productive work; it has neither had its day nor ceased to be. We are now called upon to subdivide our atom, to credit it with an unsuspected store of energy, to consider it a congeries of unsubstantial electrons. There can be no possible objection from our side; it will undo nothing that has been done, and we may have good hopes that it will lead to the doing of many new things in chemistry."

In 1802 Dalton ascertained the composition of the atmosphere, namely, that a hundred volumes contain twenty-one volumes of oxygen and seventy-nine volumes of nitrogen. In 1804 he was asked to give a course of lectures at the Royal Institution of London; and in these lectures he explained his views on the absorption of gases by liquids, on the constitution of gases, etc. As a lecturer, his manner lacked charm and gracefulness, but in spite of these defects his genius was greatly appreciated. 
He was a man of great industry, perseverance, and modesty. "It was with difficulty that he accepted any of the numerous honours proffered him. At first declining to become a candidate for the F.R.S., he was elected in 1822 without his knowledge." In 1830 he was elected one of the eight foreign associates of the Académie des Sciences, and in 1832 Oxford University conferred upon him the degree of D.C.L.

In 1822, Dalton visited Paris. Here he met many distinguished men, among whom may be mentioned, Cuvier, Laplace, Gay-Lussac, Arago, Biot, and others.

In 1836 William IV., on the recommendation of Lord Melbourne, granted Dalton a civil list pension of $£ 300$ a year.

In 1834 he received the degree of LL.D. from Edinburgh University.

Dalton's private life was monotonous, and to a certain extent uneventful. His character "was most amiable, simple, and unostentatious." His life was in his work. Science was everything to him. The chief recreation in which he indulged was bowls; he belonged to a bowling club which met at the Dog and Partridge Tavern in Manchester. Dalton was of medium height, robust and muscular; his voice was gruff, and his manner curt. When asked why he never married, he replied that he never had time (most likely impecuniosity was the primary cause). He was not, however, totally indifferent 
to the influence of women, for a warm friendship existed between him and Miss Nancy Wilson. The lady died young, but he always cherished her memory with affection. Another valued friend of Dalton's was Mademoiselle Clementine Cuvier, the daughter of the celebrated naturalist.

Concerning Dalton's atomic theory, it may be stated that he introduced the idea of weights-his theory is essentially one of weight-the relative weights of the different atoms. The first public notice of the atomic theory is contained in his paper, "An Experimental Inquiry into the Proportion of the Several Gases contained in the Atmosphere." He found that oxygen has the power of combining in two different proportions with nitric oxide, forming two distinct bodies, and that the quantities by weight of oxygen which combine are in the simple ratio of one to two. No intermediate compound could be obtained. It was this fact that led to the atomic theory, and the law of multiple proportions. "It is to Daltonwho made his living by giving private lessons at half a crown each-that we owe this knowledge which has made the fortunes of thousands, because he first told us the laws which govern chemical action."

Dalton's atomic theory is, however, somewhat different from the one of to-day. In his day the smallest particle (elementary or compound) was an atom, whereas now compound bodies are composed of atoms of the elements 
which form the compounds, and are termed molecules. The molecule of a compound contains different atoms, whereas the molecule of an element contains the same atoms.

Although not an accurate manipulator (who could be with such crude apparatus at his disposal?), he was a philosopher, a deep thinker, yea, a genius. He was gifted with that most useful "article"-scientific imagination. "He formed clear mental images of the phenomena which he studied, and these images he was able to combine and modify so that there resulted a new image containing in itself all the essential parts of each separate picture which he had previously formed."

In 1837 his health began to fail and his mental powers to decline; he had a paralytic seizure, but afterwards recovered to a certain extent.

When fainting Nature call'd for aid, And hovering Death prepared the blow.

Johnson.

Seven years later he had another attack, which proved fatal on 27 th July 1844 . With public honours his remains were buried in Ardwick Cemetery, Manchester; and a massive tomb of red granite marks the spot where the founder of the atomic theory lies buried.

Of posthumous honours, there is a beautiful statue of Dalton by Sir Francis L. Chantrey in the vestibule of the Manchester Town Hall; and in the same building 
there is a fresco, by Madox Brown, representing Dalton collecting methane or marsh gas from a stagnant pool. Opposite to Dalton's statue is one of Joule, by Gilbert. These two statues are the most beautiful sculptures Manchester possesses, and they commemorate the lifework of two men who are to the northern city what Shakespeare is to Stratford-on-Avon, or Kelvin to Glasgow. In addition to these honours to Dalton's memory, there are the Dalton chemical and mathematical scholarships awarded by the authorities of the Owens College, Manchester; and a street in Manchester bears his name.

To conclude, the "atomic theory," in the words of the celebrated French chemist Wurtz, "has thrown light upon the most recent discoveries, as it has been, since the time of Dalton, its immortal author, the most perfect instrument in the most profound theoretical conceptions, and the safest guide in experimental researches." 


\section{MENDELEEFF}

\section{I $834-1907$}

T the reign of Ivan IV., the Terrible (1555), the tribes 1 east of the Urals came into collision with Russian colonists. A tendency to form invading expeditions into Siberia now began, and by 1650, in the reign of Alexis Romanof, Siberia was entirely incorporated into the Russian Empire. The surplus population of the dominions west of the Urals has since been gradually settling in Siberia ; and, in addition, the system of severe repression which the empire has always maintained has served to people many districts with political exiles as well as convicts. To a large extent the Russian Government has also peopled Siberia by sending Cossacks to occupy the frontiers, and by subsidizing colonists of various descriptions; but the greater part of the Siberian population has been produced by immigration. Fur-hunting, escape from serfdom, from religious persecution, and from conscription, have been the main incentives to this great exodus-for despotism and servitude are deeply rooted in Russia. Whether the Duma will alter this state of affairs remains to be seen. 


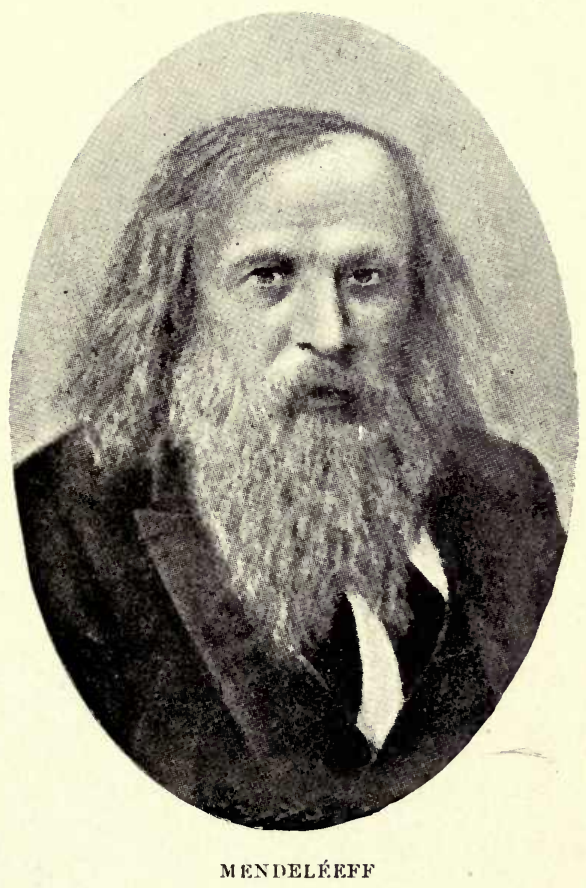

To face pays 126.] 

We have many pictures of Russian life in Siberia drawn by capable writers - Tolstoy, Maxim Gorky, Stepniak, Lermontoff, Dostoieffsky, Tourgeneff, Kompert,Tikhomirov, and others-that little is required to describe it. It has been called the land " of persecution, stripes, murder, enforced penury and hunger, with debarred constitutional, social, and other rights." Will the Duma raise the people to the level of the masses of free countries, such as England and America?

The hero of this essay, Dmitri Ivanovitch Mendeléeff (Men-de-lay-ef as the Russians call him, with the accent on the penultimate), was born on 7 th February 1834, at Tobolsk, at the conjunction of the rivers Tobol and Irtish in Siberia, and in later years became one of the most famous of chemists. His father was Principal of the Tobolsk Gymnasium, and here the son was educated until he entered the University of St Petersburg, aided by funds provided by a benefactor. Even in the inhospitable region of Tobolsk, the Government of the Czars had established a gymnasium, and there the great philosopher began his education. Thence he went to St Petersburg, and as far back as 1856 he graduated as a doctor of chemistry. Later he studied, at Paris, under Adolphe Wurtz. For a short time he was a teacher at Simferopol in the Crimea; and at Odessa he practised as a chemist. In 1859 he went to Heidelberg, where he established a private laboratory and did excellent work. In 1861, 
however, he returned to St Petersburg (the present and fifth capital of "Holy Russia"), became Professor of Chemistry in the Technological Institute, and three years later was appointed to the same chair in the University of St Petersburg.

Mendeleeff is the first name of world-wide eminence that Siberia, ${ }^{1}$ one of the largest countries of the globe, has produced.

In his early career Mendeléeff was a political economist, and no mean authority on kindred subjects, and his views were listened to by the Russian officials with the greatest respect. He was a firm supporter of autocracy and plutocracy. He had nothing of the Nihilist in his nature. Mendeléeff was tall and slim, and like many Russians had a long beard and a fine intellectual head. In his young days he was extremely reserved, and when seen in the streets of the Russian capital, he seemed buried in thought.

His lectures were fluent, forcible, and animated to such an extent that Mendeléeff was really a great orator. $\mathrm{He}$ held his audience spell-bound when discussing on chemistry.

Mendeléeff was a man of decided opinions of his own.

${ }^{1}$ Siberia covers 4,833,500 square miles-nearly forty times as great an area as that of the United Kingdom. Exile to Siberia began soon after the discovery of the country; and on an average, 20,000 persons are transported every year! 
Respected by the official classes in Russia, the police did not interfere with his laboratory, for he would not allow them-although university and other laboratories in Russia are under the control of the police.

Although of humble origin, by his loyalty to the house of Romanof, and his well-known political views, he enjoyed privileges which were denied to many of his fellow-professors and students.

Through influence, capitalists and others, Mendeléeff became rich, bought an estate near Moscow, and became scientific adviser to the Minister of Finance. He was a thrifty man, and disliked society - society was a bore to his philosophic brain and to his love of solitude. Scarcely any branch of chemistry is there, practical or philosophical, which his genius has not touched and adorned.

While he was engaged in writing the first edition of his celebrated Principles of Chemistry in 1868-70, the periodic law occurred to him, and in March 1869 he presented his views on the subject to the Physico-Chemical Society of Russia. His fame rests, and will rest for all time, on the famous periodic law of the elements. John Dalton had shown at the commencement of the nineteenth century that the elements of matter, when reduced to their smallest and indivisible forms, or atoms, combine in certain definite proportions, depending upon their weights. From Dalton's time onward some of the best 
work of savants was done in discovering as exactly as possible the weights of these atoms. This done, many laborious attempts were made, with only partial success, to link the atomic weights with the properties, etc., of the chemical elements. Newlands, De Chancourtois, Odling, Gmelin, and others made attempts to formulate the law, but success was left to the genius of Mendeléeff. He arranged the elements then known in series, standing in a sort of arithmetical progression according to their atomic weights, and chemical and physical properties. He says in his great work (loc. cit.) that "even the physical properties of selenium and its compounds, not to speak of their composition, determined by the group in which it occurs, may be foreseen with a close approach to reality from the properties of sulphur, tellurium, arsenic, and bromine. In this manner it is possible to foretell the properties of still unknown elements."

In the series some gaps presented themselves, and so great was Mendeléeff's confidence in the periodic law, that he at once predicted the discovery of new elements to fill these gaps. This was one of the most daring prophecies ever made in science-and in an exact science too, the science of weighing and measuring-but events have justified the seeming audacity.

In 1871 the prediction was made that three elements would be discovered having certain properties to fit into the gaps of Mendeléeff's table, and to these undiscovered 
elements the great Russian chemist gave the names, ekaboron, ekaaluminium, and ekasilicon. In 1875 Boisbaudran discovered gallium ; in 1879 Nilson found scandium; and in 1886 Winkler isolated germanium : elements which exactly filled the vacant places or gaps in Mendeléeff's series. Even their properties were similar to those which had been foretold. The greatness of the periodic law enables the chemist to predict what elements will be discovered in the future, and what their chief properties will be, as well as to systematize the varying properties of the elements already known.

The periodic law may be enunciated as follows: "If the elements are arranged in the order of the numerical value of their atomic weights, their properties, physical and chemical, vary in recurrent or periodic manner." And while doing this, "the periodic law keeps before us the necessity of from time to time modifying our scheme of classification: it reminds us that a typical classification is of necessity temporary, but that just by reason of its elasticity it is suited to the present needs of the chemistry of solid and liquid substances."

The work of the Russian savant on the periodic law has been severely criticized; but what great discovery has not had fault-finders? "They wholly mistake the nature of criticism who think its business is principally to find fault" (Dryden). The law deals with atomic volumes, atomic weights, specific gravities, melting-points, 
magnetic properties, hydrocarbon radicles, etc.; in fact, a full list is to be found in the index of the Principles of Chemistry-a book which gives the views of Mendeléeff on most subjects. The work has been translated into nearly all the languages of Europe.

Concerning the element argon discovered by Lord Rayleigh and Sir William Ramsay, Mendeléeff wrote to the author on 18/30 March 1895, as follows :-

A mon avis l'argon (molécules) est au $\mathrm{N}^{3}$, formée de l'azote $\mathrm{N}^{2}$ avec dédagement de chaleur, au $A^{6}$, si $A=6.6$ de $1^{\text {re }}$ sérié. La première hypothèse est, pour moi, la plus probable, comme j'avais déjà communiqué dans la Société Chimique Russe.

When Mendeléeff delivered the Faraday Lecture at the Royal Institution in 1889, he said : "The law of periodicity enables us to perceive undiscovered elements at a distance, which formerly were inaccessible to chemical vision; and long ere they were discovered new elements appeared before our eyes possessed of a number of well-defined properties. ..." Since then argon, helium, neon, xenon, metargon, krypton, radium, and possibly other forms of matter have been, and may be, discovered, throwing wondrous light on the structure of material things, but by no means invalidating Mendeléeff's famous periodic law-that is, as far as we know at the present time. It is possible that the law may be modified as time rolls on. The evolution or mutability of the elements may throw new light on the nature of the chemical element - the law of combination in simple proportions, and 
even the law of the conservation of matter (vide the researches of Curie, Ramsay, Landolt, and others).

In 1902 , in a paper entitled "An Attempt towards a Chemical Conception of the Ether," he suggested the existence of two elements having a smaller atomic weight than that of hydrogen, and forming the first two members of the zero group, which comprised the chemically inactive, non-valent gases, helium, neon, argon, xenon, and kryton; and the first of these two elements he regarded as the ether. He suggested that it is an element having an atomic weight almost incomparably small compared with hydrogen, incapable of forming compounds, but possessing the property, owing to its small atomic weight and extremely high velocity of its atoms, of penetrating and pervading all other substances, just as argon and helium enter into and dissolve in water and other liquids, or hydrogen passes through platinum and palladium. He thinks that coronium, whose spectrum has been found in the solar corona, is one of these two elements, and the ether the other. Of coronium, Mendeléeff says that "it wanders, perhaps for ages, in the regions of space, breaks from the shackles of the earth, and again comes within its sphere, but still it cannot escape from the regions of the sun's attraction, and there are many heavenly bodies of greater mass than the sun."

In 1887 Mendeleeff worked on the nature of solutions, and he regarded them as "homogeneous liquid systems 


\section{BIOGRAPHIES OF SCIENTIFIC MEN}

of unstable dissociating compounds of the solvent with the substance dissolved." This, he said, was one of the several possible hypotheses. He also worked on the laws of the expansion of gases at low tensions, and as far back as the year 1861 he reached the idea of the "absolute boiling-point" (the critical temperature of Andrews) as that temperature at which a liquid cannot exist as a liquid, but forms a gas that cannot pass into the liquid state under any pressure whatever, and at which the cohesion and the latent heat of evaporation are both nil.

His great book, The Principles of Chemistry, in two large volumes, is a philosophical treatise, and its footnotes occupy the greater part of the work.

In 1877 he published another book on the Naphtha Production in America and the Caucasus. This led to his journey to the petroleum fields of America at the expense of the Russian Government; and up to the time of his death he was the leading expert in all conferences on the mineral oil question in Russia.

Mendeléeff was an indefatigable worker, even down to the day of his death, and living only for science. When, in 1887, there was a total eclipse of the sun, he ascended in a balloon alone to make observations. Alone he effected dangerous alterations in the balloon valves, and wrote an account of his observations.

Although elected a member of almost every scientific 
academy and society in the world, he was black-balled by the Imperial Academy of Sciences of St Petersburg. This was due to jealousy and revenge! Once he had the honour to be consulted by the Russian Government regarding education, and he preferred one of his own to that of Count Tolstoy. The count's detectives followed him about for years, but found nothing against him. All the same, Tolstoy had him black-balled at the Academy! Later on in his career Mendeléeff refused the honour; but, as Miss Ellison says, "the best test of the value of a man's work is the reputation it has gained outside his own country."

Mendeléeff died on Saturday, 2nd February 1907within five days of the seventy - fifth anniversary of his birth.

The Czar Nicholas telegraphed to his widow : "Please accept my deepest sympathy in your terrible loss, which I also share. Russia has lost one of her best sons in the person of Professor Mendeléeff, who will ever remain in our memory."

Three days after the death of Mendeléeff, his colleague and friend, Professor N. Menschutkin, died. The news of Mendeléeff's death found him lecturing, and the sad tidings so affected him that he quitted the lecture theatre of the university at once, and in twenty-four hours he died suddenly.

In conclusion, Mendeléeff's whole writings are coloured 
by his views on the famous periodic law, and he says in the preface to The Principles of Chemistry, "that the entire scheme of the work is subjected to the law of periodicity."

Such is a short account of Russia's greatest chemist.

The rivers of Siberia, the native country of Mendeléeff, even in their lower latitudes, are ice-bound from the beginning of November to the beginning of May; and during the winter the smaller tributaries freeze to the bottom. . . The grim story of political persecution and astounding cruelties as practised in "Holy Russia" revolt against humanity. The fiendish cruelty of the Russian soldier in flogging, kicking, and torturing prisoners is proverbial. The officer in charge of a convoy of prisoners on their way to Siberia "expresses the hope that the prisoners may suffer all the tortures of Hades for ever, and taste a fair sample of them even upon this earth."

And don't you whine, that in your youth

You had to bear the cold;

For, when you go to hell, forsooth,

You get it hot, I'm told.

Maxim Gorky.

This is the country where Mendeleeff was born, and lived the earlier portion of his existence. It may have had something to do in moulding his character- "dediscit animus sero quod didicit diu." 



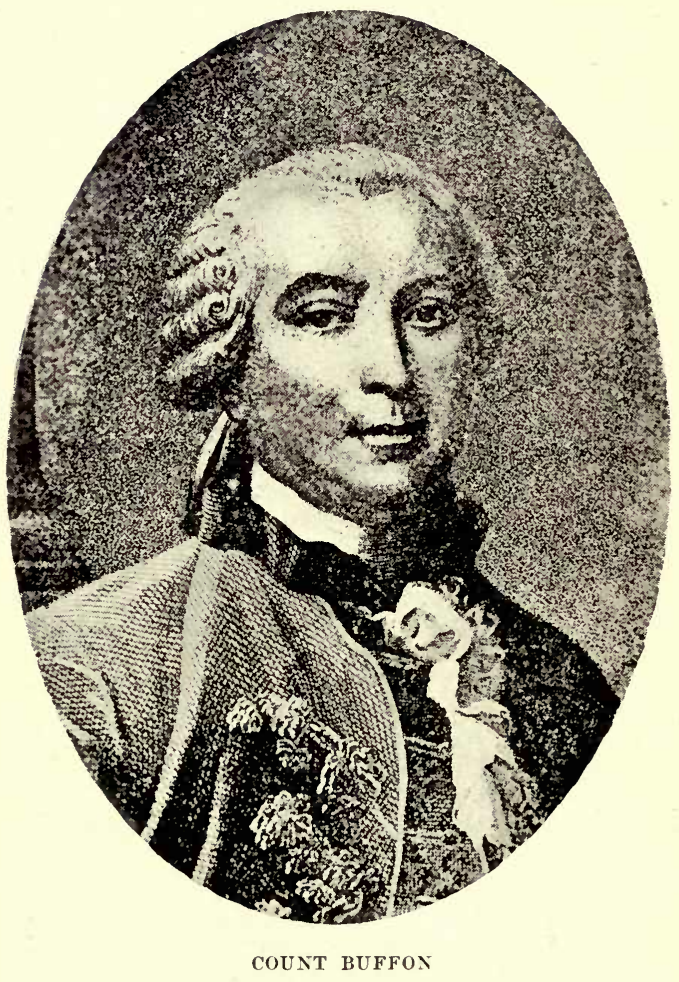

[To face page 137. 


\section{BUFFON}

$1707-177^{8}$

$\mathrm{L}^{\mathrm{I}}$

INN EUS and Buffon were born and died in the same years; this identity of dates, and the importance of the services which they rendered to natural history, are the only similitudes in their lives. Linnæus was poor, extremely poor; the poverty of which Marie Corelli speaks in The Sorrows of Satan: while Buffon was the scion of a noble and rich family.

Georges Louis Le Clerc (Comte de Buffon) was born at Montbard, in Burgundy, on 7th September 1707, and at school displayed a great liking for mathematics and astronomy.

It was in 1727, while travelling in Italy, that he received the news of his mother's death. This event placed him in possession of $£ 12,000$ a year; but he did not settle on his estate until he reached the age of twenty-five. On his return to his ancestral home, he resolutely followed a course of study and research for fifty years. His studies were pursued at a building situated at the extremity of his beautiful garden. This 
building was called the "Tour de St Louis," and here Buffon wrote most of his books and memoirs. Jean Jacques Rousseau, before he entered the "Tour," used to fall on his knees and kiss the threshold, stating that its possessor was the greatest zoologist of the age, and a master of style. Prince Henry of Prussia called this building "the cradle of natural history." Here Buffon wrote and worked for fifty years, frequently offending the Church by his evolutionary theories, which he retracted in order to please the Sorbonne-the Faculty of Theology of the University of Paris. In 1751, when he was forty-four years of age, the Sorbonne condemned him to retract the heresy which he had made in publishing these words: "The waters of the sea have produced the mountains and valleys of the land; the waters of the heavens, reducing all to a level, will at last deliver the whole land over to the sea, and the sea successively prevailing over the land, will leave dry new continents like those which we inhabit." His recantation states that: "I declare that I had no intention to contradict the text of Scripture; that I believe most firmly all therein related about the Creation, both as to order of time and matter of fact. I abandon everything in my book respecting the formation of the earth, and generally all which may be contrary to the narrative of Moses."

The late Mr W. E. Gladstone, writing to Dr J. A. Lahm on the latter's book, Evolution and Dogma, said: 
"Evolution tends to elevate and not to depress the Gospel."

Buffon was a thinker-a true philosopher, with advanced views - and the best ideas of the Encyclopædists (Voltaire, Rousseau, and Diderot) were realized in his Histoire Naturelle and Époques de la Nature. He was undoubtedly the centre of a powerful and energetic group of naturalists which characterized a great part of the eighteenth century. He was the father of the modern evolutionist.

His great work, Histoire Naturelle, in fifteen volumes, appeared between 1749 and 1767 ; and his literary style was unapproached by any of his scientific contemporaries. Mirabeau said of Buffon that he was "le plus grand homme de son siècle et de bien d'autres"; and Rousseau said that he was "la plus belle plume du siècle." His style was also praised by Diderot, Voltaire, and others.

Buffon was a handsome man, with courtly and diplomatic manners, wide culture, and a splendid genius, which he himself called "a supreme capacity of taking pains." His stateliness and polished courtesy, his ready wit and graceful bearing, his erudition and ideas, not without a certain grandeur, raised Buffon on so high a pedestal, that we cannot wonder if France and Europe generally worshipped him.

He translated Newton's Fluxions, and was familiar 
with the physics and chemistry of his time. "Before Laplace, he elaborated a hypothesis as to the origin of the solar system; before Hutton and Lyell, he realized the causes like those now at work had, in the long past, sculptured the earth; he had a special theory of heredity not unlike Darwin's, and a by no means narrow theory of evolution, in which he recognized the struggle for existence and the elimination of the unfit ("the survival of the fittest' of Herbert Spencer, and the 'natural selection' of Charles Darwin), the influence of isolation and of artificial selection, but especially the direct action of food, climate, and other surrounding influences upon the organism": and his writings paved the way for the doctrine of descent. Buffon saw, with a philosophic eye, the unity of nature; and no doubt he would have seen more, and written more, if orthodox creeds had not stood in his way. He had always to keep an eye on the Sorbonne!

Living in the renaissance of science, Buffon was no believer in the permanent stability of species. He says, e.g., " the pig does not appear to have been formed upon an original, special, and perfect plan, since it is a compound of other animals; it has evidently useless parts, or rather parts of which it cannot make any use-toes, all the bones of which are perfectly formed, and which, nevertheless, are of no service to it. Nature is far from subjecting herself to final causes in the formation of her 
creatures." He believed that species have altered, due to changes in the environment in past ages of the world; and he hinted that there may have been a common ancestor of the ass and horse, and of the ape and man.

I don't object, not I, to know

My sires were monkeys, if 'twas so,

I touch my ear's collusive tip,

And own the poor relationship.

J. R. Lowell.

Buffon was an evolutionist, and the most "suggestive naturalist of the eighteenth century." During the same century there was great enthusiasm for natural history, as the following names, among others, bear evidenceRœsel, De Geer, Schäffer, Réaumur, and Bonnet.

Buffon anticipated many important theories, such as "the struggle for existence," "artificial and natural selection," "geographical isolation," "descent," and the action of the environment in producing structural changes which were preserved by heredity. Although faulty in many of his ideas, Buffon helped to pare the way to the modern theory of evolution.

Of his foibles, it may be mentioned that he was personally vain-turbine raptus ingenii; so were the most eminent writers, Voltaire and Rousseau, of the age of Louis XV. $\mathrm{He}$ was fond of jewellery and gold-laced clothes, and in his young days he was a dandy, as far as dress was concerned. He said of himself : "I know but five great geniuses, Newton, Bacon, Leibnitz, Montesquieu, and 
myself." However, he was always willing to hear the opinions of others, and to admire their work.

In 1733, four years after the death of Jean Gaston, Grand Duke of Tuscany (the last of the De Médicis), Buffon was elected a member of the Académie des Sciences.

He greatly improved and enlarged the much neglected Jardin des Plantes, having been appointed the director, and continued the work of regeneration begun by Dufay.

In 1744 Buffon published his Théorie de la Terre, which was ultimately included in the Histoire Naturelle. $\mathrm{He}$ had similar ideas to those of Laplace and Kant, namely, that the earth and other planets were thrown off from the sun in the molten state, and, after cooling, dry land, seas, mountains, etc., were formed by various agencies that are slowly working at the present day. Concerning the place where life began on this planet, he suggested, in his Epoques de la Nature, the polar regions.

As the globe cooled, those regions would be the first to reach a temperature under which life is possible. The Comte de Saporta, whose researches give large support to Buffon's theory, remarks that the richest fossil-yielding rocks are found in northern latitudes of $50^{\circ}$ to $60^{\circ}$ and beyond, and show that as far back as Silurian times the North Pole was warm enough to maintain life of a tropical character, and that it was the centre of origin of successive forms down to the Tertiary epoch; the Miocene flora, which has now to be sought $40^{\circ}$ farther south, being profusely represented. In Carboniferous times a warm, moist, equable climate prevailed over the whole globe, due, as De Saporta argues, to arrest of radiation by a highly vaporous atmosphere, and also, perhaps, to the greater diffuseness of the sun's light by reason of his larger volume. 
In 1749 appeared his Histoire Naturelle des Oiseaux, in eight volumes and six supplements-a beautiful illustrated work, in which is painted in glowing colours the manners and habits of birds. In particular and minute observation he excelled, and by his indefatigable researches he made most valuable additions to science.

Buffon rejected the principles of classifications in use in his day, and threw his subjects into groups. He was not free from bias, and his prepossession for a favourite doctrine led him astray. He rejected the works on classification of Ray, Tournefort, Bernard de Jussieu, and Linnæus; but in his Histoire Naturelle des Oiseaux he felt more and more the necessity of arranging birds according to their affinities.

In 1774 Buffon published his Histoire des Minéraux - a work of great importance and value.

The same year that Voltaire and Rousseau died, Buffon ended his labours, and joined the majority on 16th April 1778. His last words to his son were: "Never quit the path of honour and of virtue; it is the only way to be happy." He was buried with public honours in the Cimetière du Père la Chaise.

He died one year before the advent of the French Revolution, and his only son was guillotined fifteen days before the fall of Robespierre. During the Reign of Terror the remains of the great zoologist were torn from the tomb, and the monument which was erected to 
Buffon's memory was razed to the ground. Such was the wanton recklessness of the revolutionists-even the dead were not safe in their graves! The despicable meanness of the mob in rifling the grave of "the aristocrat Buffon" was to steal the leaden coffin in which he was buried. With this exception, however, the tomb was restored by admirers of the great man.

Buffon was a naturalist of the highest order; indefatigable in his work, independent in his ideas, and although rich and the friend of kings, idleness was unknown to him. "He opposed the extreme systematizers, who seemed to think it the end of science, not so much to know about an object, as to be able to make it and fit it into their system." Huxley, writing in 1894, said that "we do not possess, at this moment, a history of even the little group of British mammals up to the level of the work of Buffon and Daubenton, now nearly a century and a half old." Huxley said in appreciation of Buffon: "I am not likely to take a low view of Darwin's position in the history of science, but I am disposed to think that Buffon and Lamarck would run him hard both in genius and fertility. In breadth of view and extent of knowledge these two men were giants, though we are apt to forget their services."

Saint-Hilaire said of Linnæus and Buffon: "Linné, un de ces types de la perfection de l'intelligence humaine 
où la synthèse et l'analyse se complétent l'une l'autre, et, pour ainsi dire, se font équilibre: Buffon, un de ces hommes puissants par la synthèse, qui franchissent d'un pied hardi les limites de leur époque, marchent seuls en avant, et s'avancent vers les siècles futurs en tenant tout de leur génie comme un conquérant de son épée." 


\section{BERTHELOT}

\section{827-1 907}

$N 1827$ the Government of Charles X. sent a fleet to
the coast of Morea to join the English in putting a stop to the barbarous warfare between the Greeks and the Turks. De Rigny and Codrington, the two admirals, acted in concert in a battle fought in the Bay of Navarino, in which the Turkish fleet was destroyed. It will be remembered that Lord Byron, the poet, fought in this battle, and had the great pleasure of seeing Greece made an independent state. In the same year Pierre Eugène Marcellin Berthelot was born on 25th October 1827, at Paris, and for half a century was a most famous chemist, writer, and philosopher. He was the son of a distinguished physician, Dr Jacques Martin Berthelot, and received his education at the Lycée Henri IV. In early life he won an important prize at an open competition for philosophy, and then devoted himself to scientific studies, beginning with investigations on acids and fermentation. In 1851, at the age of twenty-four, he entered the Collège de France, as preparateur of the lectures on chemistry 


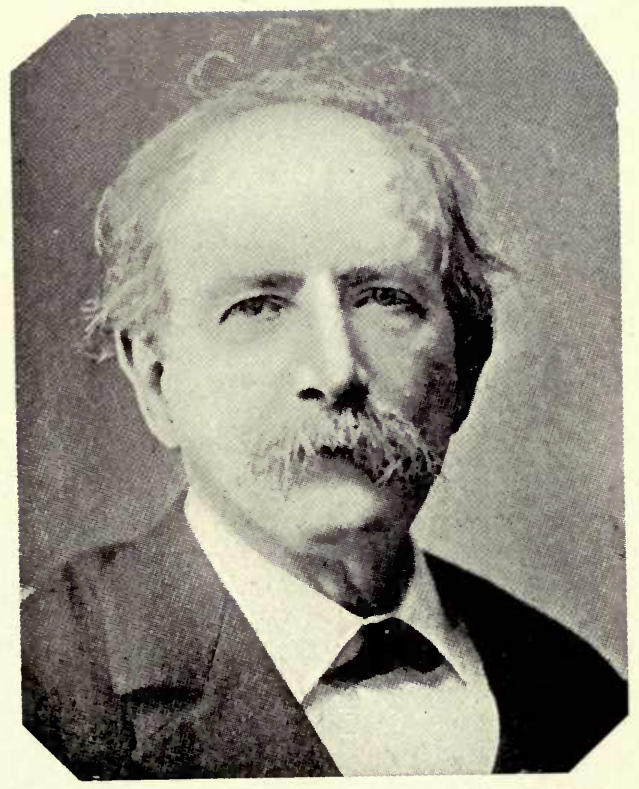

PROF. M. BERTHELOT

To face page 146. ] 

(under Balard, the discoverer of bromine). In 1854 he took his degree of docteur ès sciences with a remarkable thesis on the "Combinaisons de la Glycérine avec les Acides et Réproduction Artificelle des Corps gras neutres."

In 1859 he was appointed to the chair of chemistry in L'École de Pharmacie, holding the post for five years. In 1864 a new chair, that of organic chemistry, was created for him at the College de France, which he occupied until his death; and here it was that he worked with a determination unequalled by any other chemist. He produced over a thousand memoirs, embracing every department of chemistry. Although Wöhler, in 1828, produced urea artificially, and Kolbe synthetized acetic acid in 1845, Berthelot was undoubtedly the creator or founder of organic synthesis. Monsieur Henri Poincaré says of Berthelot that "c'est non seulement un grand chimiste, mais aussi un grand philosophe. Il possédait un esprit universel. Sa découverte sur la synthèse des corps organiques suffirait pour immortalizer son nom. Ses travaux sur les corps explosifs ont rendu également au pays d'inappréciables services."

This remarkable man had "many irons in the fire," for he was not only a great chemist, but a politician, philosopher, and author.

The theories and discoveries of Berthelot are grouped round two great ideas - the synthesis of organic com- 
pounds, and the investigation of the laws of dynamical chemistry. Probably the most important syntheses of his are the production of acetylene from carbon and hydrogen, and methane or marsh gas, by means of the well-known Berthelot's reaction; and of dynamical chemistry, his most important discovery is "the law of maximum work." His scientific labours were immense, and he completely revolutionized chemistry in more departments than one. He transformed agriculture; proved that inorganic and organic bodies obey the same laws; established "la théorie des affinités"; and invented thermo-chemistry.

In 1861 he was awarded the Jecker prize by the Académie des Sciences for his researches on the syntheses of organic compounds. The first half of the nineteenth century was devoted to analytical chemistry-this being due to the great work of Berzelius. The second half, however, was the era of Berthelot or synthetical chemistry. Since his discovery of the synthesis of acetylene, a vast number of organic bodies have been discovered by the aid of synthesis; and there is no limit to these discoveries in organic chemistry. Tartaric acid, citric acid, alcohol, lactic acid, and a host of other compounds, both vegetable and animal, have been synthetized. It is not improbable that even albumen or protoplasm will yield to synthetical methods. It is quite within the bounds of possibility that chemistry 
some day will discover something that will make the world independent of wheat and meat. Berthelot believed in the possibility of wheat-growing and cattleraising being superseded by the discovery of artificial substitutes for the necessaries of life. It may seem to the uninitiated a mere dream, but to the chemists this vision of the future is quite within the bounds of possibility. Chemistry in the past sixty years has done more to make mankind independent of Nature than all the other agencies in the world since the beginning of time. This is a big statement, but it is literally true. Chemistry, by its application to agriculture this past half-century, has doubled the world's producing power, has, in fact, put Nature in harness and made her do double work by the stimulation of growth.

It is only within the past sixty years that synthetic chemistry has come to take its proper place in the scientific world: what a powerful instrument of research it has proved; and this is due to the original stimulus given to it by Berthelot. Berthelot's idea of the synthesis of substances that will take the place of wheat and meat is the most audacious flight of fancy that scientific imagination has ever yet taken, but it need not, because of that, be classed among the impossibilities. Berthelot was justified by accomplished facts in stating that applied science has done more for mankind in the last three-quarters of a century than all the progress in 
all ages that preceded it. And yet, applied science is only in the first early dawn of its power.

Berthelot was quite sure that physics and chemistry would soon solve the problem of aerial navigation, and he significantly remarked that when they do so "customhouses will fall of themselves." That would be something like a revolution in the world's institutions, but it would be second to the discovery of artificial wheat and meat.

Although glycerine was discovered by Scheele in 1779 , and its formula established by Pelouze in 1836, it was not until 1854 that its true composition was known. This was due to Berthelot, who proved that it is an alcoholic compound capable of interacting with three molecules of such acids as acetic and palmitic.

In 1860 Berthelot's book, Chimie Organique fondée sur la Synthèse, was published. It was the first of its kind, being based entirely on synthesis. His methods were simple and direct. By means of the electric spark, carbon and hydrogen united to form acetylene; or by the action of electricity on a mixture of hydrogen and carbon monoxide, the same gas is formed; also by the action of the spark on a mixture of hydrogen with carbon disulphide vapour or cyanogen. The conversion of acetylene into ethylene, and the synthesis of alcohol were also important reactions. Acetylene polymerizes, under the influence of the electric spark, into benzene, and 
many of its derivations were formed by Berthelot. He also formed methane by passing the vapour of carbon disulphide and sulphuretted hydrogen over hot copper; and by the action of carbon monoxide on a hot solution of caustic potash, potassium formate was produced, the formate yielding formic acid on distillation with hydrochloric acid. He formed hydrocyanic acid by the action of the electric spark on a mixture of nitrogen and acetylene.

Such were a few of the numerous syntheses of Berthelot, or the building up of chemical compounds, many of which were only obtained through the instrumentality of life, either animal or vegetable.

His contributions to chemical literature range over practically every department of the science : philosophical, historical, physical, pure, and applied.

In 1864 Berthelot began his great work on thermoshemistry, and in 1879 he published his Essai de Mécanique Chimique fondée sur la Thermo-chimie. Although Favre, Silbermann, Andrews, Hess, and Thomsen had previously worked on problems bearing on heat and chemical changes, Berthelot is generally looked upon as the founder of thermo-chemistry.

His laws are the following:-(1) The heat disengaged in any reaction is a measure of the chemical and physical work accomplished in the reaction. (2) The total thermal value of a reaction is dependent only on the initial and 
final states of the changing system.

(3) "The Law of Maximum Work," or "the theorem of the necessity of reactions": every chemical change accomplished without the aid of external energy tends to the formation of a body, or system of bodies, the production of which evolves the maximum amount of heat. This law of Berthelot is of considerable importance, as it will often enable the chemist to decide beforehand whether a contemplated reaction is or is not possible by direct means, and if, because accompanied by absorption of heat, not possible in the direct way, it may enable him to bring it about by making it one of a series of reactions, the total effect of which is an evolution of heat. . . This law is the fundamental principle of Berthelot's thermo-chemistry: "The quantity of heat evolved in a reaction measures the sum of the physical and chemical changes which occur in that reaction"- "ce principe fournit la mesure des affinités chimiques."

Berthelot's agricultural station and laboratory were at Meudon, and here experiments on vegetable soils, the fixation of atmospheric nitrogen in soils by the agency of microbes, the action of electricity on the growth of plants, etc., were conducted. Berthelot states that twentyfive pounds of nitrogen per annum per acre might be fixed by bacteria.

Berthelot's work on the explosive wave, his classical experiments on the union of carbon and hydrogen, and 
his work on thermo-chemistry have served as the startingpoint of numerous investigations by other chemists in various parts of the world. Berthelot's genius and activity are unparalleled in the history of chemistry. In 1862 he published Leçons sur la Principes Sucrés; in 1863, Leçons sur l'Isomérie; and in 1864, Leçons sur les Méthodes Générales de Synthèse en Chimie Organique.

In 1889 he was elected Secrétaire perpétuel de l'Académie des Sciences, and thereby became the most influential man of science in the French capital. On the death of Pasteur, in 1895, he was elected a member of the Académie Française.

A few words about the world-famed Institut de France may not be out of place, as Berthelot was an illustrious member of that body. It was erected in the seventeenth century on the Quai Conti, opposite the Louvre. It is a handsome building, with a façade in the form of a crescent, flanked with wings, and surmounted by a dome. Five different academies (Berthelot belonged to two) have their homes here-namely, the Académie Française (devoted to the superintendence of the French language), the Académie des Sciences (devoted to the sciences), the Académie des Belles-Lettres (devoted to the study of the ancient languages), the Académie des Beaux-Arts (for painting, sculpture, and music), and the Académie des 
Sciences Morales et Politiques (for moral philosophy and politics).

The Académie des Sciences was founded by Louis XIV. - the Royal Society of London being founded, about the same time, by Charles II.

During the siege of Paris, Berthelot was President of the Scientific Committee of National Defence, and was occupied in the manufacture of explosives, and in 1883 he published, in two volumes, his work, Sur la Force des Matières Explosives. It is a valuable contribution to the science of the subject.

His other books are: Science et Philosophie (1886); La Révolution Chimique Lavoisier (1890); Traité Pratique de Calorimétrie Chimique (1893); Thermochimie Données et Lois Numériques, in two volumes (1897); La Synthèse Chimique (1897); Science et Morale (1897); Renan et Berthelot, Correspondance (1898); Chimie Végétale et Agricole, in four volumes (1899); Chimie Animale, Principes Chimiques de la Production de la Chaleur chez les Etres Vivants, in two volumes (1899); Science et Education (1901); and several volumes on historical chemistry which will be alluded to later in this chapter.

Berthelot was also a politician, and he formed part of the Cabinet of Monsieur Goblet, as Ministre de l'Instruc tion Publique in 1885, and was also a member of the 
Bourgeois Cabinet as Ministre des Affaires Étrangères in 1895. He was always a friend of England, and by his colleagues "was accused of having made too many concessions to this country." This led to Berthelot's retirement, as Baron de Mohrenheim of Russia (that country being France's ally) was dissatisfied with him. There was no entente cordiale in those days, and Russia was jealous of any concession made to England! France's friends abroad were uneasy on the subject of her foreign policy, as she was caught coquetting with England and Italy, and it was asked whether her policy had suddenly changed. In those days Russian jealousy of England was everywhere visible, and every attempt was made by the Czar's Government to thwart her policy. It is all changed now, as Berthelot suggested, and England is on the best of terms with France and Russia.

Concerning the Boer War, the following details may be of interest. It was stated that after sending the evermemorable telegram to Kruger in January 1896, the German Emperor made overtures to France with a view to assist the Transvaal, but the French Government offered to support England if Germany intervened in favour of the Boers. Having been asked whether the above statements were true, Berthelot replied, on 21 st October 1899, as follows:-

I see no harm, no State secret at stake, to prevent me from answering your letter, or from authorizing you to publish this. While I was 
at the Quai d'Orsay events in the Transvaal did not fail to engage my attention from the humanitarian point of view, from that of our natural interests in Madagascar, and also from that of the important private interests concerned in the gold mines. I had occasion to correspond on this subject with our excellent Consul, Monsieur Aubert, and to give him all the help in my power. I also received the Envoy of the Boer Republic kindly, but without wishing to play with him that immoral game which consists in encouraging the weak in resistance in which one is not resolved to take part. Neither England nor Germany ever suggested to me an exchange of their views with those of the French Government on the question. I do not even remember what was the object of any conversation started either by Lord Dufferin, the Ambassador of England, or by Count Münster, the Ambassador of Germany, at my Wednesday receptions.

French sympathy was strongly enlisted in favour of the Transvaal, but France never dreamt of intervention in any form.

Berthelot had a remarkable memory, as the following words of one of his most intimate friends testify :-

One day I remember he was turning over before me the leaves of a copy of one of our important reviews. In a quarter of an hour he had reached the last page. I chaffed him, saying that he did not seem to attach much importance to its contents. He affirmed that he had read it. So I put him to the test, questioning him on each of the articles in the review. He replied without hesitation or error; he had actually read more than a hundred pages in a few minutes. Another recollection at the Académie des Sciences on one occasion someone made an allusion to a certain work, almost unknown, and two or three hundred years old. Berthelot gave the name of the author, mentioned the subject of the book, and indicated the place it occupied in the library of the Institut de France. I have seen at close quarters a good many illustrious men in my time, and there have only been three before whom I had the sentiment of grandeur: Berthelot, Renan, and Taine. What was most admirable about Berthelot was that, although he was universally acknowledged as a great scientist, 
he never lost his tenderness of heart. Madame Berthelot, it may be said, was all in all to him. He had often said that if she died he would not long survive her. But no one thought his prophecy would be realized so suddenly. His death is a great loss for the scientific world and for France, but it is a still greater loss for his friends.

Berthelot had a good heart in other circles than those of his own family. Although the most influential man of science in France, he greatly appreciated and aided the work of others. As an example of his goodness, it may be stated, en passant, that he presented over forty of the author's memoirs to the Académie des Sciences, all of which have been published in the Comptes Rendus de l'Acadénie des Sciences. Dozens, yea hundreds, of scientists owe Berthelot a deep debt of gratitude.

His public works will best attest his fame,

Whilst private worth adds value to his name.

Most of the honours awarded to men of science were bestowed upon Berthelot: besides these he was a GrandCroix de la Légion d'Honneur (an order founded by Napoleon I.); Grand-Croix de l'Ordre Royal de Charles III. of Spain; Grand-Croix de l'Ordre Royal de l'Étoile de Roumanie; and he possessed other orders. Berthelot was made a senator for life. Life members of the French Sénat are now fast dying out, and will become as extinct as the dodo.

Berthelot commenced his career in 1851-eight days before Louis Napoleon overthrew the Constitution by a coup d'état, and to commemorate the fiftieth anni- 
versary (1851-1901), or his scientific jubilee, there was an imposing demonstration of esteem and regard organized in honour of the event. Representatives of all countries, academies, societies, universities, etc., were present at this great meeting of 24th November 1901. It was more like the vast gatherings of ancient times than one in these democratic days. It was held in the amphitheatre of the historic Sorbonne, ${ }^{1}$ and here Berthelot received addresses and a beautiful gold medal (by Chaplain), the latter being subscribed for by most of the chemists of the world. The medal (the author possesses a replica in bronze of this medal) has on its obverse side a portrait of Berthelot in profile, and the following words: "Marcellin Berthelot. La Synthèse Chimique. La Science Guide l'Humanité"; and the reverse side pictures the great chemist at his table, Truth illuminating him with a torch, while France, holding a flag, presents him with a laurel crown. The inscription is as follows: "1851. Pour la Patrie et la Verité. 1901."

Not content with his great discoveries in every department of pure and applied chemistry, Berthelot produced the following unique and erudite books on

${ }^{1}$ The Sorbonne was erected by Cardinal Richelieu in 1629. The amphitheatre is a splendid oak-panelled room, adorned with the celebrated fresco by Puvis de Chavannes. 
historical chemistry :-Les Origines de l'Alchimie (1885); Collection des Alchimistes Grecs, in three volumes (1887-88); Introduction à la Chimie des Anciens et du Moyen Âge (1889); and La Chimie au Moyen Âge, in three volumes (1893): the first is an "essai sur la transmission de la science antique"; the second on "l'alchimie syriaque"; and the third volume is on "l'alchimie arabe." These historical works are of the most learned kind, necessitating laborious researches in the libraries of Leyden, London, and Paris. Manuscripts in the Bibliothèque Nationale, that of St Mark at Venice, the palæographs of the tenth century, the alchemical papyri of Leyden of the third century, the ancient philosophies of Syria, Arabia, Greece, and those of the Middle Ages, were all utilized by Berthelot in writing the works mentioned above.

Concerning these books the Société Alchimique de France addressed him, at his jubilee, in the following words :

La Société Alchimique de France adresse à l'occasion de son glorieux Jubilé, à Monsieur Marcellin Berthelot, l'hommage de sa respectueuse et profonde admiration.

Elle s'incline devant le génie de Berthelot, qui a réellement constitué la Chimie Synthétique et qui écrit ce volume immortal: "Les Origines de l'Alchimie."

The Society was founded for the purpose of investigating the researches, doings and sayings of the old alchemists. 
The Finale! On 18th March 1907 a terribly dramatic event occurred, for both Monsieur and Madame Berthelot died within a few minutes of each other.

On the afternoon of 18 th March he attended a meeting of the Académie des Sciences. Returning, he went to his wife's bedside, and devoted himself to cheering her in her suffering. At half-past five he withdrew with his sons to his study. There, with tears in the old man's eyes and trembling voice, he said to them: "My boys, if your mother were to die I could not survive her." His sons returned to their mother's room while the savant set himself resolutely to work in an effort to forget his troubles.

A quarter of an hour later Madame Berthelot's illness came to a sudden crisis, and before her husband could be called she had passed away. The eldest son went to his father's study and informed him of Madame Berthelot's death. The scientist, who was sitting writing, turned round in his chair as his son entered. Hearing the terrible news, he gasped "Mon Dieu!" and fell back in his seat with his hands clasped over his eyes. A minute later his hands fell limply to his side. Berthelot was dead! The great chemist succumbed to heart failure in the eightieth year of his age. ${ }^{1}$

1 Berthelot and his wife were passionately attached to each other, and their married life was one of the most beautiful on record. As Monsieur Leygues said, addressing Berthelot: "Durant ces sombres jours (1870), votre courage fut soutenu par la femme éminente qui est la grâce et le charme de votre foyer." 
Berthelot received a public funeral, and his remains were placed in the Panthéon on 25th March 1907, side by side with those of his wife. The crowds which gathered to see the two bodies laid to rest together in the nation's great mausoleum proved the popularity and universal renown of Berthelot, who did perhaps as much for chemistry as Pasteur did for medicine, if not more; for not only did he open up new fields of inquiry and lead the way to innumerable discoveries and developments, but he practically founded new branches of science, namely, synthetic and thermo-chemistry. Berthelot was one of those "prodigious" men who honour every country and every epoch. He made science the highest and noblest end of man. With Berthelot science became a real creative power. He proved that organic and inorganic chemical laws are identical. He did not get so far, by the imperfect means at his disposal in his laboratory, as to create a leaf or a fruit, but he did produce certain essential parts of the whole. What a field did he open up to human activity! Chemistry at once created artificial substances akin to natural ones, and by leading the way in this immense field of discovery Berthelot placed himself in the foremost ranks of the benefactors of humanity.

A few words about the burial-place of Berthelot will form a suitable conclusion to the present chapter. The 
Panthéon (the Westminster Abbey of Paris) was the church of St Geneviève, and its foundation stone was laid by Louis XV. in 1764 . In 1885 it was secularized, under the name it now bears, and all traces of religious worship were removed. The frescoes in the interior, by Puvis de Chavannes, Laurens, Cabanel, and others, are among the finest compositions of the nineteenth century. In the crypt were buried the remains of Voltaire, Rousseau, Mirabeau, Marat, Victor Hugo, and others; and it was Berthelot who, in 1897, was instrumental in having Voltaire's and Rousseau's sarcophagi opened to see if their bodies had been tampered with, as stated, but the great philosophers' remains had not been removed. Berthelot, in examining the remains of Rousseau, found fragments of the winding-sheet substances of an antiseptic and aromatic nature, such as are used in embalming, some teeth, and even a little hair still adhering to the frontal part of the skull, and forming a sort of crown, or tonsure, like that of monks. 



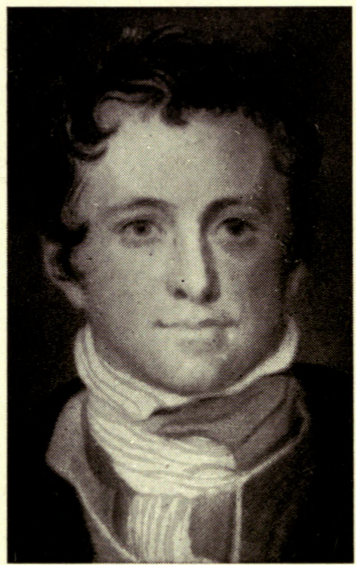

SIR HUMPHRY DAVY, BART. 


\section{DAVY \\ 1778-1 829}

7 WO years after the Declaration of Independence of America, and the same year that an alliance between France and America was signed, England's great chemist, Humphry Davy, was born at Penzance, in Cornwall, on 17th December 1778-four years after the discovery of oxygen.

He went to school until he was fifteen years of age, and was then apprenticed to a surgeon-apothecary. In these young days he was endowed with great observing power and a keen appreciation of Nature. In 1798 he began the study of chemistry by reading Lavoisier's Traité de Chimie; and about this time Davy became acquainted with Mr Davies Gilbert (afterwards President of the Royal Society) and Dr Beddoes. He was employed by the latter to superintend the Pneumatic Institution at Bristol, and from this date his scientific career began-a career that placed Davy's name in the front rank of scientific investigators. "His was an ardent boyhood," says Professor Forbes; "educated in a manner somewhat irregular, and 
with only the advantages of a remote country town, his talent appeared in the earnestness with which he cultivated at once the most various branches of knowledge and speculation. He was fond of metaphysics; he was fond of experiment; he was an ardent student of Nature; and he possessed at an early age poetic powers which, had they been cultivated, would, in the opinion of competent judges, have made him eminent in literature as he became in science. All these tastes endured throughout life. Business could not stifle them-even the approach of death was unable to extinguish them. The reveries of his boyhood on the sea-worn cliffs of Mount's Bay may yet be traced in many of the pages dictated during the last year of his life amidst the ruins of the Colosseum."

Davy's first paper, published while at Bristol, was on beat, light, and respiration. The memoir laid the foundations of the present dynamical theory of heat. At this period he showed great abilities, was young, enthusiastic, energetic, and ambitious. $\mathrm{He}$ was bound to succeed.

While at Dr Beddoes', Davy was introduced to Samuel Taylor Coleridge (poet and philosopher) and Robert Southey (poet, essayist, and historian), and there is no doubt that meeting such men helped to develop his genius and erudition. Davy was one of the most remarkable chemists of his or any age. Chemistry in 
those days was a young science. "The chains with which Stahl and his successors had so long bound the limbs of the young science had been broken by Lavoisier."

Modern chemistry was developing, and developing at a rapid rate. There were giants in those days whose names are immortal: Berthollet, Proust, Gay-Lussac, Thénard, Dalton, Berzelius, and others.

In 1797 Davy discovered the anæstbetic properties of nitrous oxide gas - a gas used largely by the dentist. About the same time he published his Researches-a work "characterized by vigour and novelty of conception." This work attracted the attention of Count Rumford, the founder of the Royal Institution in London, who required a lecturer for the Institution. Davy was appointed to the post, and about a year later he was elected professor of chemistry. He came to London with the utmost enthusiasm, but "his ungainly appearance was against him," as his lectures were delivered before the élite of London society. Soon, however, "the ability of the young man won the approval of this aristocratic audience, until, in a year or two, he was courted by the highest society in the metropolis, and took that position in the fashionable world which was so well suited to his temperament."

The words of Dr S. Johnson are appropriate for Davy's career in London :- 
$\mathrm{Me}$ toils and pleasures alternate share,

Books and the converse of the fair,

To see is to adore them;

With these and London for my home,

I envy not the joys of Rome,

The circus or the Forum.

At the Royal Institution he had plenty of time for research, a good laboratory, and influential friends who took the greatest interest in his work and welfare. How different it was with poor Linnæus!

Concerning Davy's first course of lectures at the Royal Institution, it has been stated that

... the enthusiastic admiration which they obtained is scarcely to be imagined. Men of the first rank and talent, the literary and the scientific, the practical and the theoretical, blue-stockings and women of fashion, the old and the young-all crowded, eagerly crowded, the lecture room. His youth, his simplicity, his natural eloquence, his chemical knowledge, his happy illustrations and well-conducted experiments, excited universal attention and unbounded applause. Compliments, invitations, and presents were showered upon him in abundance from all quarters; his society was courted by all, and all appeared proud of his acquaintance.

The age of Davy was essentially the age of the voltaic battery in chemical research; and what he did with the battery, recently invented by Volta, were discoveries in chemistry second to no others.

The researches, indicated in his Bakerian lecture of 1806 , were rewarded with a prize of three thousand francs by the Académie des Sciences. He began his electrochemical researches in the early years of the last century. In his Elements of Chemical Philosophy he says :- 
Electrical effects are exhibited by the same bodies, when acting as masses, which produce chemical phenomena when acting by their particles; it is not therefore improbable that the primary cause of both may be the same, and that the same arrangements of matter, or the same attracting powers, which place bodies in the relations of positive and negative, i.e. which render them attractive of each other electrically, and capable of communicating attractive powers to other matter, may likewise render their particles attractive, and enable them to combine, when they have full freedom of motion.... That the decomposition of the chemical agents is connected with the energies of the pile, is evident from all the experiments that have been made; as yet no sound objection has been urged against the theory that the contact of the metals destroys the electrical equilibrium, and that the chemical changes restore it, and, in consequence, that the action exists as long as the decompositions continue.

The Wollaston battery of two hundred cells was constructed for Davy in 1807, and by it many brilliant researches were performed, which excited the rivalry of foreign savants. Among these were the investigations of Gay-Lussac and Thénard, entitled Recherches PhysicoChimiques, published in 1811, and in which are to be found many remarkable observations on the physical and chemical effects of the voltaic battery.

Davy's brilliant researches with the Wollaston battery caused Napoleon I. to have one constructed in 1813 for the École Polytechnique; and one day the Emperor, when speaking to Berthollet, said: "Pourquoi ces découvertes n'avaient pas été faites en France." "Sire," said Berthollet, “c'est que jusqu'à jour nous n'avons pas possédé de pile voltaïque assez puissante." Napoleon had one constructed with six hundred cells (with elements of 
copper and zinc). This battery, although non-existent now, was the means of producing valuable discoveries in the hands of Gay-Lussac and Thénard.

Davy proved that oxygen was not the acidifying principle of acids, as stated by Lavoisier; and he led the way to the ultimate definition of an acid.

In 1803 Davy was elected F.R.S. ; in 1807, Secretary of the Royal Society; and in 1820, its President. During these years a vast number of papers were published by him; and he published the following books: Elements of Agricultural Chemistry (1813); Elements of Chemical Philosophy; Salmonia, or Days of Fly-fishing; and Consolation in Travels, or the Last Days of a Philosopher (published in 1831, two years after his death). The last-named book contains some finely written theories on ethical and moral questions, with descriptions of Italian scenery.

In his book on Agricultural Chemistry, Davy says :-

Agricultural chemistry has not yet received a regular and systematic form. It has been pursued by competent experimenters for a short time only. . . I am sure you will receive with indulgence the first attempt made in this country to illustrate it by a series of experimental demonstrations. ... It is evident that the study of agricultural chemistry ought to be commenced by some general inquiries into the composition and nature of material bodies, and the law of their changes. The surface of the earth, the atmosphere, and the water deposited from it, must either together, or separately, afford all the principles concerned in vegetation; and it is only by examining the chemical nature of these principles that we are capable of discovering what is the food of plants, 
and the manner in which this food is supplied and prepared for their nourishment. . . . Nothing is more wanting in agriculture than experiments, in which all the circumstances are minutely and scientifically detailed.

The attractions of society and his early death (he was only fifty) stopped his work on agricultural chemistry; and it was not until 1840, eleven years after Davy's death, that Liebig published his ever famous work on the same subject.

Rumford and Davy proved that heat was not matter, as had been previously supposed, but a form of energy - the vis viva of the molecules. But the crowning discoveries of Davy were those necessitating the use of the electric battery. To Davy, "the electrolysis of every chemical compound was a new application of the great law established by Newton: 'to every action there is an equal and opposite reaction."' By means of the electric battery he decomposed bodies which were generally regarded as elements or simple bodies.

On 19th October 1807 Davy isolated the metals potassium and sodium by electrolyzing potash and soda. In the former case, potassium and hydrogen were evolved at the negative pole, and oxygen at the positive pole of the battery. When Davy first saw the metallic globules of potassium, "he could not contain his joy-he actually bounded about the room in ecstatic delight; and some little time was required for him to compose himself sufficiently to continue the experiment." This was the 
reward for six years' hard work. His discoveries he described in his second Bakerian lecture before the Royal Society.

The decomposition of potash and soda, proving their compound nature, led to the discovery of barium, strontium, calcium, magnesium, and boron. Thus, by means of the electric battery, Davy proved that the alkalis and alkaline earths were compounds, and contained metals. These discoveries were the foundation of Davy's fame, and are, perhaps, "the greatest in chemistry." As Professor T. E. Thorpe says : "It was a wonderful triumph, and all London marvelled at the production from such common and familiar substances of new, white, soft, easily-oxidized, shining metals, which the eye of man had never seen before!"

In 1812 Davy was knighted, and married a rich Scottish lady, Mrs Apreece. The same year he resigned the chair at the Royal Institution, and in 1813 travelled with his wife on the Continent.

From 1802 to 1812 his labours were intense, and his discoveries were of the highest importance.

In 1813 Michael Faraday became Davy's assistant, and he helped the master in the work on the explosive chloride of nitrogen.

In 1815 (the year of the battle of Waterloo) Sir Humphry Davy invented the miner's safety-lamp. For this invention he was created a baronet in 1818; and the 
coal-owners of the north of England presented him with a service of plate worth $£ 3000$. How many lives this invention has saved from a horrid death it is impossible to estimate.

Davy proved the elementary nature of chlorine, and that hydrochloric acid is a compound of chlorine and hydrogen. His experiments were always most convincing as well as brilliant. While in Paris, he proved that iodine was an element, using the simplest of appliances.

Unremitting devotion to chemistry and society had undermined his constitution to such an extent that in 1826 he was attacked by paralysis, and was forced to relinquish most of his work. He visited the Continent for the benefit of his health; but another attack of paralysis seized him while visiting Rome. He, however, rallied sufficiently to continue the homeward journey. At Geneva he was attacked again, and died on Royal Oak Day (29th May) 1829. Sir Humphry Davy was buried in the cemetery outside the city of Geneva, Switzerland.

He was an untiring and enthusiastic worker, a brilliant experimentalist, an eloquent lecturer, a genius : and "he was full of eager desire to know the secrets of the world in which he lived"; in fact, as Cuvier said of him, "he occupied the first rank among the chemists of this or of any other age."

His work on the elemental nature of chlorine, iodine, etc., his synthesis of hydriodic acid, and his work on 


\section{2}

\section{BIOGRAPHIES OF SCIENTIFIC MEN}

the chloride and iodine of nitrogen are examples of first-class work; but they are as nothing to the isolation of the metals of the alkalis and alkaline earths. The era of Davy has been called the "golden age of chemistry in this country"; certainly it was most brilliant, and one never to be forgotten in the history of science.

Sir Humphry Davy said: "The foundations of chemical knowledge are observation, experiment, and analogy. By observation facts are distinctly and minutely impressed on the mind; by analogy similar facts are connected; by experiment new facts are discovered; and in the progress of knowledge, observation, guided by analogy, leads to experiment; and analogy, confirmed by experiment, becomes scientific truth."

Sir Humphry Davy "was a somewhat vain and irritable man, whom early success had made haughty to his inferiors. Indeed, in the recollections of Faraday, who as a young man attended upon him in his travels, we have a rather disagreeable picture of the savant who had forgotten the "pit out of which he was digged." "

Later on, however, he appreciated the talents of Faraday, although he strongly opposed the latter's nomination for the fellowship of the Royal Society. Was he jealous of Faraday's successes? Davy was never popular with assistants and colleagues. He was far too 
imperious, and was "regardless of minor etiquette." Snobbish to aristocrats, arrogant to inferiors, "it is mortifying to think that this great man, captivated by the flatteries of the fashionable world, lost much of the winning simplicity of his early manner and his devotion to science."

Davy received every honour awarded to men of science, but he was refused the Order of the Bath, which he expected.

Of posthumous honours, the Royal Society awards a Davy medal; Dr Ludwig Mond has endowed a research laboratory (called the "Davy-Faraday Laboratory") at the Royal Institution; and there is a statue to his memory in Market Jew Street, Penzance.

It was Count Rumford who was instrumental in bringing Davy to the Royal Institution; therefore a few words about him will not be out of place. Benjamin Thompson Rumford was born in America in 1753, and at the outbreak of the War of Independence he embraced the royalist cause. He was a commander of the King's American Dragoons; in 1784 he entered the Bavarian service, rose to be Minister of War, and was created Count of the Holy Roman Empire. In 1806 he married the widow of Lavoisier, but the marriage was a failure, and they separated in 1809.

Rumford was a celebrated physicist. He invented the 


\section{BIOGRAPHIES OF SCIENTIFIC MEN}

photometer known by his name, and his researches ${ }^{1}$ in heat and light are well known to men of scienceso much so that the Royal Society perpetuates his name by awarding a Rumford medal for researches in physics. $\mathrm{He}$ was the founder of the Royal Institution, and a philanthropist. Rumford died on 21st August 1814, and lies buried in the Cimetière d'Auteuil, Paris.

The large and beautiful monument on his grave was destroyed by a shell during the Commune in 1871, but was restored in 1876, at the expense of the American Academy of Arts and Sciences of the College of Harvard, at Cambridge, Massachusetts, U.S.A.

1 Mémoires sur la Chaleur (1809); Recherches sur la Chaleur développée dans la Combustion (1813), etc. 



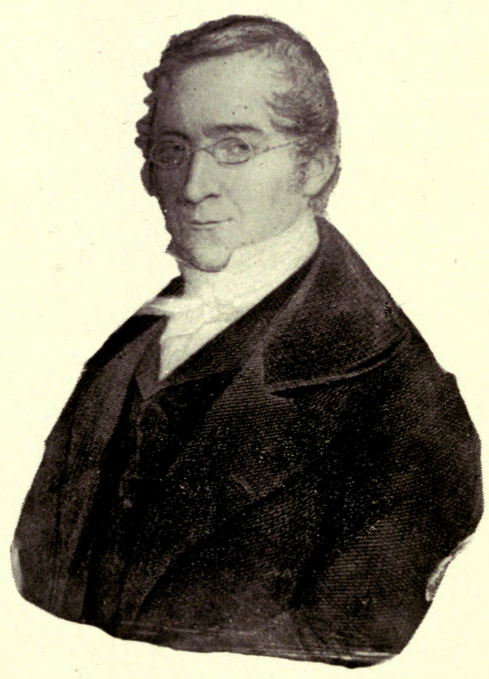

GAY-LUSSAC 


\section{GAY-LUSSAC \\ I $77^{8-I} 850$}

I OUIS JOSEPH GAY-LUSSAC, the brilliant chemist and physicist, was born at St Léonard-le-Noblat (Haute-Vienne), France, on 6th December 1778.

The same year (1793) that witnessed the execution of Louis XVI. and Marie Antoinette, Gay-Lussac came to Paris and entered the École Polytechnique. Although so young, it was his delight and ambition to be in Paris. "Paris," said Heinrich Heine, "is not simply the capital of France, but of the whole civilized world, and the rendezvous of its most brilliant intellects." GayLussac studied for three years at the École Polytechnique, after which he was promoted to the Département des Ponts et Chaussées (a Government department including everything connected with the making and repairing of roads, bridges, canals, etc.). His next position was as an assistant to C. L. Berthollet-a celebrated chemistand in 1801, a year after the terrible and decisive Battle of Marengo, Gay-Lussac published his first paper on "La Dilatation des Gaz et Vapeurs," which was 
followed by "Le Perfectionnement des Thermomètres et Baromètres," "L'Action Capillaire," "La Fusion des Vapeurs," etc.

In 1804 Gay-Lussac, in conjunction with Alexander von Humboldt, published an important memoir on the chemical and physical properties of air taken at an altitude of 23,000 feet. Ballooning in the early part of the nineteenth century was attended with the greatest risks; but he and Humboldt were intrepid naturalists, and undertook the investigation of the atmosphere at great heights -hygrometry, atmospheric electricity, aqueous tension, atmospheric pressure, etc., were some of the subjects investigated. Their memoir was published by the Académie des Sciences, and contained the announcement that hydrogen and oxygen combine to form water in the proportion of two hundred volumes of hydrogen to one hundred volumes of oxygen. It was from this discovery that Gay-Lussac was led to the most important law of volumes, which he discovered in 1809. This was his chef d'cuvre; but more anon.

Gay-Lassac investigated the nature of volcanic gases -more particularly hydrochloric acid gas-and "the vapours that rise from the fumarolles cause the sublimation of the chlorides of iron, copper, lead, and ammonium; iron glance and chloride of sodium (the latter often in large quantities) fill the cavities of recent lava streams and the fissures of the margin of the crater." In the Annales de 
Chimie, tome xxii., p. 415 , he gave the chemical process in the formation of specular iron.

In 1809 , the same year that he discovered the law of volumes, Gay-Lussac was elected Professor of Chemistry at his alma mater-the École Polytechnique, Paris-and remained at the great military school for twenty-three years. In 1832 he transferred to the same chair in the Jardin des Plantes.

In 1823 he published a memoir on the dynamics of earthquakes, in which he says that "the earth, so many centuries old, still preserves an internal force, which raises mountains, overturns cities, and agitates the entire mass. Most mountains, in issuing from the bosom of the earth, must have left vast cavities, which have remained empty, at least unless they have been filled with water and gases."

The existence of alkaline metals was prophesied by Lavoisier in 1793 ; and potassium and sodium were discovered by Davy in 1807, by means of the voltaic pile; and in the following year Gay-Lussac discovered a new process which yielded both potassium and sodium more abundantly than the voltaic pile. This was by the action of white-hot iron on the hydroxides of potassium and sodium. No doubt the brilliant researches of Davy stimulated Gay-Lussac and his collaborateur Thénard, and in their Recherches Physico-Chimiques (1811) are to be found many remarkable observations on the action of the voltaic pile which Napoleon had constructed for 


\section{8 BIOGRAPHIES OF SCIENTIFIC MEN}

the École Polytechnique. Much to his credit, the greatest military genius the world has ever seen was always interested in the work of men of science, and greatly esteemed their talents. It was through the influence of Napoleon (then First Consul) that Alexander Volta was awarded a gold medal, ${ }^{1}$ a prize of 6000 francs (both of the Académie des Sciences), and the Cross of the Légion d'Honneur, for his electrical researches.

In the year (1809) that Napoleon defeated the Austrians at Wagram, and annexed Tuscany and the Papal States, Gay-Lussac announced his discovery of the law of volume. This all-important law is generally stated, in these days, in the following words: When gases or vapours, either elementary or compound, unite together to form a new product, the resulting product always occupies two volumes. Occasionally the resulting volume is the sum of the constituent volumes, but usually there is condensation. The following examples illustrate the law of Gay-Lussac :-

$$
\begin{aligned}
& \mathrm{H}+\mathrm{Cl}=\mathrm{HCl} \\
& \text { Volumes } 1+1=2 \\
& 2 \mathrm{H}+\mathrm{O}=\mathrm{H}_{2} \mathrm{O} \text { (steam) } \\
& \text { Volumes } 2+1=2 \\
& \mathrm{~N}+3 \mathrm{H}=\mathrm{HN}_{3} \\
& \text { Volumes } 1+3=2 \\
& \mathrm{NH}+\mathrm{HCl}=\mathrm{NH}_{4} \mathrm{Cl} \\
& \text { Volumes } 2+2=2
\end{aligned}
$$

The resulting volume is always two.

1 The medal bore the following inscription: " $\AA$ Volta, séance $d u$ II Frimaire an IX." Frimaire was the third month of the calendar of the first French Republic-from 21st November to 20th December. 
Gay-Lussac stated in the Mémoires de la Société d'Arcueil, tome ii., p. 207, that "lorsque deux gaz se combinent, leurs volumes mesurés à la même température et à la même pression sont dans des rapports simples." It will be seen that Gay-Lussac anticipated the great law of Avogadro, although it was left to the Italian physicist to distinguish between the ultimate particles of compounds and elements-between molecule and atom. As Roscoe and Schorlemmer say: "The discovery by Gay-Lussac of the law of volume - combination, together with Avogadro's explanation of the law-served no doubt as most valuable supports of Dalton's atomic theory; but the truth of this latter theory was still further asserted by a discovery made by Dulong and Petit in 1819. These French chemists determined the specific heat of thirteen elementary bodies, and found that the numbers thus obtained, when compared with the atomic weights of the same bodies, showed that the specific heats of the several elements are inversely proportional to their atomic weights; or, in other words, the atom of each of these elements possesses the same capacity for heat. Although subsequent research has shown that this law does not apply in every case, it still remains a valuable means of controlling the atomic-weight determinations of many elements."

Gay-Lussac was the inventor of the tower, known by his name, in the manufacture of sulphuric acid. Formerly the nitrous fumes were allowed to escape into the air, but 
now they are utilized according to Gay-Lussac's method. This consists in absorbing the vapours by means of sulphuric acid of a specific gravity-176. On treating this nitrous sulphuric acid with steam, nitrous fumes are evolved and passed again into the chamber, while the diluted sulphuric acid is again concentrated.

In 1808 Gay-Lussac and Thénard prepared boron by decomposing boron trioxide with potassium. They also prepared boron fluoride by heating together boron trioxide and calcium fluoride; and they determined the composition of boric acid both synthetically and analytically. In 1809 Gay-Lussac discovered the chemical action of light on a mixture of hydrogen and chlorine; and in 1810, he and Thénard examined hydrofluoric acid, which had been discovered by Scheele in 1772. In the same year (1810) they established the elementary nature of phosphorus, an important investigation which led to the discovery of the element's various allotropes.

In 1814, the year that Napoleon defeated the Prussians and signed his abdication of the throne of France, GayLussac and Davy discovered hydriodic acid, and examined the element iodine which had been previously isolated by Courtois (1811). Gay-Lussac also examined bromine, and demonstrated the compound nature of fluor spar.

In 1815 Gay-Lussac made a most important discovery, namely, that of cyanogen gas; and proved that this gas habitually imitated the element chlorine in its com- 
binations; that it is the radicle of hydrocyanic acid and cyanic acid; and that prussic acid is a compound of carbon, hydrogen, and nitrogen. Cyanogen, it may be mentioned, plays an important part in many organic reactions and compounds.

Gay-Lussac observed that the action of chlorine on hydrocyanic acid replaced the hydrogen forming cyanogen chloride, or acide chlorcyanique of his day; and he found that when beeswax was bleached by means of chlorine, it lost hydrogen and took up an equal volume of chlorine. At a royal ball at the Tuileries, in the reign of Charles $X$. (brother of Louis XVI.), the guests were "much annoyed by the irritating vapours which came from the wax candles to illuminate the apartments." This was due to the fact that the manufacturer had used chlorine to bleach the wax, and the irritating vapours contained hydrochloric acid.

In 1816 "Gay-Lussac made the remarkable observation that when a crystal of common potash alum is hung up in a saturated solution of ammonia alum it grows exactly as if it had been placed in the solution from which it was originally obtained. From this fact he drew the conclusion that the molecules of these two alums possess the same form." This was the beginning of Mitscherlich's law of isomorphism, which was discovered in $\mathbf{1 8 1 0 .}$

Gay-Lussac, by igniting potassium carbonate in iodine vapour, or chlorine gas, obtained an evolution of oxygen 
and carbon dioxide. His chemical and physical researches were incessant, and most important discoveries were made by this indefatigable genius.

Gay-Lussac discovered the monochloride and trichloride of iodine, and dithionic acid; and "by heating sodium in dry ammonia, Gay-Lussac and Thénard obtained an olivegreen, easily-fusible mass, sodamide, hydrogen being separated. This substance with water forms sodium hydroxide and ammonia; with carbon monoxide, it forms sodium cyanide and water; and with dry hydrochloric acid it forms sodium and ammonium chlorides."

Gay-Lussac also worked on the products of the explosion of gunpowder in both confined and open spaces. This was the beginning of the vast province of artillery science; and his elaborate and beautiful researches on the fulminates of silver and mercury were of the highest order. Mercury fulminate is prepared by warming alcohol with nitric acid and mercuric nitrate. It forms silky, lustrous prisms, which explode with the utmost violence upon being heated or struck; hence it is extensively used for percussion caps, dynamite cartridges, etc. The analogous silver fulminate is still more explosive.

In 1831 Gay-Lussac was elected a member of the Chamber of Deputies; and in 1839 he was created a peer of France by King Louis Philippe. The latter's education, it may be remarked, was entrusted to the 
celebrated Madame de Genlis, and her teaching was planned on the principles of Rousseau.

In addition to his discoveries and researches in chemistry, Gay-Lussac was a brilliant physicist. The law of the expansion of gases was discovered by him and Charles: a gas expands $\frac{1}{273} \mathrm{rd}$ of its volume for each degree of temperature (Centigrade) above $0^{\circ} \mathrm{C}$; or, in other words, the law of Gay-Lussac states that all gases in all conditions present one coefficient of expansion0.00367 ; that is, when beated from $0^{\circ}$ to $100^{\circ}$ they expand like air, namely, a thousand volumes of a gas measured at $0^{\circ}$ will occupy 1367 volumes at $100^{\circ}$. Regnault, in the year that Gay-Lussac died (1850), showed that Gay-Lussac's law is not entirely correct.

Gay-Lussac invented an alcoholmeter. It is used to determine the strength of spirituous liquors; that is, the proportion of pure alcohol which they contain. $\mathrm{He}$ also invented the syphon barometer. In this barometer both the longer and shorter limbs are closed, but the shorter one contains a capillary aperture through which the atmospheric pressure is transmitted.

Gay-Lussac invented an apparatus for ascertaining vapour densities. It involved the determination of the volume of a given weight of vapour; but this method and those of Dumas, Bunsen, and Hofmann have been superseded by that of Victor Meyer, or the air-displacement method. 
Gay-Lussac did valuable work on vapour densities, vapour tensions, and solubilities. The effect of variation of temperature on the solubility of different salts was very clearly demonstrated by him; and he was the first to have recourse to the graphic method of expressing solubilities.

In addition to numerous memoirs, Gay-Lussac wrote a Cours de Physique, Cours de Chimie, Leçons de Chimie, etc.

His work was a brilliant conglomerate of faits accomplis in the earliest days of modern chemistry and physics. He was a man of extensive learning-homo multarum scientiarum-and was always ready to give the best advice to students and others.

Gay-Lussac received most of the honours that fall to the lot of men of science. He died on 9th May 1850, a hundred and nine days before the death of the "bourgeois king," Louis Philippe, and a year before the coup d'état of Napoleon III.

Among posthumous honours, there is the Lycée GayLussac at Limoges, and the Rue Gay-Lussac, Paris, near the Panthéon and Luxembourg.

In conclusion, "the alchemists were right. There is a philosopher's stone; but the stone is itself a compound of labour, perseverance, and genius, and the gold which it produces is the gold of true knowledge, which shall never grow dim or fade away." 



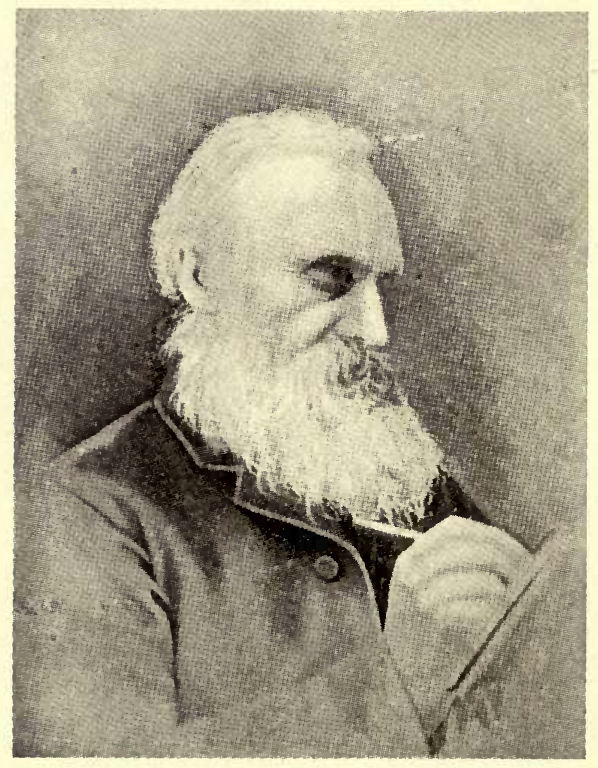

I.ORD KELVIN

‘To face page 185. 


\section{KELVIN}

I 824-I 907

\section{W ILLIAM THOMSON (afterwards Baron Kelvin)} was born at Belfast on 25th June 1824, and was the son of James Thomson, LL.D., formerly professor of mathematics at the University of Glasgow. At the early age of eleven, Thomson entered Glasgow University, and finally St Peter's College, Cambridge. In 1845 he was second wrangler and first Smith's prizeman. After leaving Cambridge, he went to Paris and studied chemistry under Regnault. In 1846 Thomson was elected to the chair of natural philosophy in Glasgow University, and held the post for over fifty years. In 1841 he published a paper on the "Uniform Motion of Heat in Homogeneous Uniform Bodies." Thomson was a profound mathematician and physicist, "a prince of science and benefactor of the world."

Even at eleven years of age the young philosopher was solving the problem-how long it had taken the earth to cool since it first came together as a white-hot globe : and only a few years ago, he stated that the earth 
was not more than twenty million years old, and would not probably sustain life more than ten million years longer; for in that time the sun would be cool, and therefore organic life on this planet would be impossible.

In conjunction with the late Professor P. G. Tait, he, in 1867, produced a classical work on Natural Philosophy. He devoted a vast amount of time in studying the constitution of matter-the sizes of atoms and molecules, and the force which holds them together. Thomson came to the conclusion from examining the thickness of the wall of a soap bubble, the electrical action of small copper and zinc discs, the refraction of light, and the dynamical theory of gases, that the molecules of air are about large enough to put twentyfive millions of them in a row an inch long. "Imagine a globe of water six inches in diameter magnified to the size of the earth, and its molecules in the same proportion; then, when the drop had become a world, the individual particle would be about the size of small shot, certainly not larger than a football." These calculations were before the discovery of the corpuscular radiations of radium, polonium, actinum, etc., which the experimental researches of Professor J. J. Thomson, of the Cavendish Laboratory, Cambridge, proved to be at least a thousand times smaller than the chemical atom; although the calculations of Lord Kelvin concerning the atom still remain true. He did not care for the latter-day work 
with radio-active bodies, and frequently alluded to electrons as "chipped atems."

The forces of the material universe, such as cohesion, adhesion, heat, electricity, magnetism, etc., engaged the attention of Kelvin. Though the amount of energy in the universe is constant, it is always being degraded from higher to lower forms. This is Kelvin's law of the "dissipation of energy," which means that the universe is not a clock wound up to go for ever. Energy is every moment running down, and sometime in the measureless past must have been started, and sometime in the unbounded future it must be wound up again, or stop for ever.

Kelvin's theory of vortex motions, as applied to atoms and molecules, is of vast importance. It is a type of motion in a frictionless, incompressible, primordial fluid which might account for the known properties of matter.

Many of Kelvin's papers are only understood by expert mathematicians. There is hardly a department in physics which he did not make his own: molecular physics, electricity, dynamics, the theory of gases, heat, thermo-dynamics, the theory of energy, etc.

Kelvin was also a great inventor, and his appliances are manufactured by Messrs James White of Glasgow, who employ nearly two hundred skilled workmen and electricians. 
His discovery of the "law of the retardation" of electric currents, and the invention of the mirror galvanometer and the syphon recorder, rendered submarine telegraphy possible.

The Atlantic cables of 1858 and 1865 broke, the latter after a fortnight's use. This, according to the late $\mathrm{Mr}$ G. H. Smith, was due to strains caused by the "paying out of the cable from coils instead of from reels. During the gales encountered by the Agamemnon the upper part of the main coil shifted, and became a mere shapeless tangled mass. Kinks were produced, and breakage was the result." Ultimately the cable was laid in 1866, and Thomson received the honour of knighthood.

He invented a mariner's adjustable compass (suitable for iron ships), i.e. the compass was constructed so as to neutralize the effect of terrestrial magnetism on iron. The compass was first adopted by the mercantile service, and afterwards by the Admiralty. At first the Admiralty would not look at Kelvin's compass! It may be mentioned that the same authorities resisted the use of lime-juice for scurvy-and thereby thousands of men lost their lives!

Among Kelvin's inventions are his quadrant electrometer for measuring minute electric currents, his tidepredicting machine, his deep-sea sounder, his kilowatt balance, his multicellular electrostatic voltmeter, etc. Kelvin patented his inventions, and thereby reaped a 
fine harvest, proceeds of his inventions, for at his death he was worth $£ 169,000$. He did not look upon it as derogatory for a man of science to reap the pecuniary benefit derived from the sale of the inventions of his own brain; by so doing he was enabled to add considerably to the general store of knowledge.

Kelvin's theory of the "dissipation of energy" was announced in a paper on "The Secular Cooling of the Earth," in 1852. He argued that the earth was a hot body like the sun; that it has gradually cooled, is still cooling; and that ultimately it will become cool to the core: life will then be untenable owing to the lowness of temperature.

In 1885 he delivered the Bakerian lecture on the "Electro-dynamics of Qualities of Metals," and in it is published for the first time his "electric convention of heat." Papers on mathematical and physical subjects flowed from his pen, and his inventions were not less numerous. Kelvin, like Newton, was a profound natural philosopher, and the higher mathematics were as playthings to his gigantic and fertile brain.

Among other papers of Kelvin's may be mentioned: "Rigidity of the Earth," "The Mathematical Theory of Elasticity," "The Thermal Effects of Fluids in Motion," "The Determination of a Ship's Place at Sea from Observation of Altitudes," "Approach caused by Vibration," "An Account of Carnot's Theory of the Motive 
Power of Heat," "On the Dynamical Theory of Heat," and numerous others are to be found in the Transactions of the Royal Societies of London and Edinburgh. His papers began to appear in book form in 1882 .

In 1851 he was elected F.R.S. (along with Huxley and Stokes), and, after having received the Royal and Copley medals, he was in 1890 chosen President of the Royal Society. $\mathrm{He}$ was one of the eight foreign associates of the Académie des Sciences; D.C.L. of Oxford, and LL.D. of Cambridge, Edinburgh, and Dublin Universities; and he possessed most of the honours awarded to men of science.

Lord Kelvin was twice married. His first wife, the daughter of $\mathrm{Mr}$ Crum, F.R.S., died in 1870, and his second wife was the daughter of the late $\mathrm{Mr}$ Blandy of Madeira. For many years Lady Kelvin was his companion and helper; and they sailed in their yacht the Lalla Rookh over many seas, for Lord Kelvin was a navigator as well as a physicist and mathematician.

In 1892 he was made a peer of the realm by Queen Victoria. He was a Knight of the Prussian Order Pour le Mérite, a Grand Officer of the Légion d'Honneur de France, a Commander of the Order of Leopold of Belgium, a Grand Cross of the Victorian Order, a Member of the Order of Merit, etc. As Lord Kelvin left no heir the barony became extinct. 
Lord Kelvin was hearty and genial, and generally wore a winning smile; and he was the most modest of great men.

On one occasion he paid a visit with a friend to some well-known electrical works. They were escorted over the workshops by the senior foreman, a man of much intelligence and an enthusiastic electrician. Entirely unaware of his visitor's identity, he minutely explained the details of the plant and machinery, and lectured him in his rôle of layman quite professionally. Lord Kelvin's friend was on the point of interrupting several times, but an amused signal from the great master of electricity kept him silent. When the tour of inspection was complete, Lord Kelvin quietly turned to the foreman and asked, "What, then, is electricity?" This was a poser for the man, who, somewhat shamefacedly, confessed that he could not say. "Well, well," said Lord Kelvin gently, "that is the only thing about electricity which you and I do not know."

Lord Kelvin was the greatest teacher of physics of his day, but his lectures were never simple; in fact, his "popular addresses" were more suitable for wranglers than anybody else. His subjects were so simple to him that he frequently overlooked the fact that he took his audience clean out of their depth. He was essentially a teacher of teachers.

In 1896 Lord Kelvin celebrated the jubilee of his professorship at the Glasgow University, and on this occasion men of science from all parts of the world did honour to the great physicist; and he was presented with the Arago gold medal by the Académie des Sciences. Numerous addresses were presented to him from the various universities, academies, and societies of the world, 
and when thanking the company for the addresses, he remarked :

You heap coals of fire on my head; you reward me for having enjoyed for fifty years the privilege of spending my time in the work most congenial to me, and in the happiest of surroundings. You could not do more for me if I had spent my life in hardships and dangers, fighting for my country, or struggling to do good among masses of our population, or working for the benefit of the people in public duty voluntarily accepted.

I feel profoundly grateful; but when I think how infinitely little is all that I have done, I cannot feel pride-I only see the great kindness of my scientific comrades, and of my friends in crediting me with too much. One word characterizes the most strenuous of the efforts for the advancement of science that I have made during fifty-five years, and that word is failure. I know no more of electric and magnetic force, or of the relations between ether, electricity, and ponderable matter, or of chemical affinity, than I knew and tried to teach fifty years ago in my first session as professor. Something of sadness must come of failure; but in the pursuit of science inborn necessity to make the effort brings with it much of the "certaminus gaudia," and saves the naturalist from being wholly miserable, perhaps enables him to be fairly happy in his daily work. And what splendid compensations for philosophic failures have we had in the admirable discoveries by observation and experiment of the properties of matter, and in the exquisitely beneficent applications of science to the use of mankind, with which these fifty years have so abounded.

Two lessons are derived from the life-work of such a man as Lord Kelvin. The theoretical speculations of the philosopher, and the practical inventions of the scientist. Science must, however, in the main be directed to the actual service of man in his daily life. Science largely determines national prosperity; and in this respect Lord Kelvin's inventions are of the highest order of usefulness. 
Not only Atlantic telegraphy, the adjustable compass, but the scullery tap came under his inventive genius. Apply your knowledge! It is of little use if not capable of application. That was the law of Kelvin's life. In addition to inventions, he soared into the profoundest speculations of philosophy: the birth of worlds, the size of atoms, the cooling of the earth, etc., all engaged his attention.

If the laws of gravitation, and the decomposition of light by the prism, were the chief achievements of the immortal Newton; the magnitudes and motions of atoms, the theory of the age of the world, and oceanic telegraphy, were the principal discoveries of the immortal Kelvin.

A mere material universe, however, did not satisfy Lord Kelvin. There are such things as intelligence, volition, and emotion; the power to reason, the capacity to distinguish good and evil, and taste to admire the beautiful, which cannot be expressed in terms of length, breadth, and depth; or as qualities of solids, or liquids, or gases. There are life and mind; these no knowledge of matter has explained. "Proofs of intelligent and benevolent design lie all around us," said Kelvin. Things must be as they are either by chance, necessity, or design. Chance is out of the question, unthinkable. Grant that the properties of things, like those of numbers, for instance, could not be otherwise, have been eternally as they now exist-impossible as the supposition is-how came the 
elements of this world to be distributed as they are and in such proportions? Why gold rarer than iron, and iron than clay? Why the optical rotation of life-compounds (such as tartaric acid, lactic acid, etc.), and not of the synthetical acids? Why a globe adapted not merely in the quality of its materials but in their quantity and distribution to the wants of living beings and to their evolution? Kelvin answered firmly and unwaveringly: "Because all living things depend on one everacting Creator and Ruler."

Lord Kelvin had a limp, which was due to his early enthusiasm for curling. He had the misfortune to break his leg twice on the ice, and a third time it had to be rebroken in order to make a better setting.

The Manchester philosopher Joule had investigated the phenomena attending the evolution of heat during the passage of a current through an electrolyte, and it was proved that the total quantity of heat could be separated into two parts. "One part was expressible as the result of overcoming ordinary resistance, and the other part was due to chemical changes in the cell. He then determined the quantity of heat evolved, during a given time, in a process of electrolysis by a current of given strength; then, by applying Ohm's law, and the law stated connecting heat with resistance and current, he found the heat which would have been evolved, had a 
wire with resistance equal to that of the electrolyte been substituted for the electrolyte. The difference between these two quanties of heat is equivalent to the heat which is due to the reverse chemical combination by combustion or other means." The problem was further investigated by Lord Kelvin. He reasoned as follows:- "Let unit quantity of electricity pass through a cell of infinitely small resistance; then, by Joule's law, the work done by the current is equal to $\mathrm{E}$, the electromotive force. But $\epsilon$ gramme of one of the elements of the electrolyte has been electrolyzed, in accordance with Faraday's law. Let $\theta$ be the quantity of heat developed by the combination of one gramme of this element to reproduce the electrolyte, then, since no work is expended in any other part of the circuit

$$
\begin{aligned}
& E=J_{\epsilon} \theta, \text { and therefore } \theta=\frac{E}{J_{\epsilon}} \\
& J=\text { the mechanical equivalent of heat." }
\end{aligned}
$$

Lord Kelvin died on 17th December 1907, the result of a severe chill, and his remains were buried in the nave of Westminster Abbey. It was an ever-memorable occasion, when an enormous concourse of men of science and others attended the funeral. Kelvin's grave is next to that of Sir Isaac Newton, who was buried in 1727. On the gravestone of the latter are the words: "Hic depositum est quod mortale fuit Isaaci Newtoni." Newton's 
body lay in state in the Jerusalem Chamber, and distinguished men from all parts of Europe came to pay their last respects to the memory of the great British philosopher. Among these was no less a person than Voltaire (1694-1778). He had the greatest admiration for Sir Isaac Newton, and of this great occasion, he wrote that "if all the geniuses of the universe should assemble, Newton would lead the band." 1

In the nave of the Abbey, where Kelvin lies buried, ${ }^{2}$ there are the graves of Newton, Darwin, Lyell, Herschel, Hunter, Livingstone, and others - a veritable "Science Corner." With the death of Lord Kelvin disappears one of the grandest figures in the history of science. His country honoured itself in recognizing his merits, and England has every reason to bewail her loss, for however rich she may be in distinguished men, she cannot fail to recognize that the loss of Lord Kelvin is an irreparable one.

Although Lord Kelvin did not care for the presentday work on electrons or fractional atoms and the crumbling of the elements, his mind was free from bias; and he viewed the brilliant researches of J. J. Thomson, Ramsay, and others with the keen eye of the philosopher.

1 Voltaire's Eléments de la Philosophie de Newton (1738).

2 The inscription on the stone is "William Thomson, Lord Kelvin, 1824-1907." 
The mutability of the elements by Ramsay is most wonderful. $\mathrm{He}$ has found that the radium emanation develops into helium, and when the same emanation is passed through water it changes into neon. If it is passed through a solution of a salt of copper, it resolves itself into argon; and when copper is acted upon by the radium emanation it is converted into lithium! Argon, helium, radium, neon, krypton, and xenon are non-valent elements, and as such have not the power of combining with other elements. Thus they appear to be the wreck of the material universe, which seems to be undergoing universal dissolution. In the course of a thousand million years one cannot say what the gold and silver, the copper and lead, and much else of the solid structure of this globe may have become. Another marvellous feature is the unheard-of energies which these fragments of radium set free in their break up. The powers of Nature in this respect astonish us as much as its extent in space and time.

Whether Lord Kelvin could read the future or not as to the drift of modern investigations on electrons and emanation "it would be shallow to believe that such men as Kelvin, with faculty quickened and outlook widened in the high air to which their fame raises them, really discerned no more than we, who have only their written words for authority, can perceive that they discerned. Great position often invests men with a second sight, 
whose vision they lock up in silence, content with the work of the day."

At the 1903 meeting of the British Association, Kelvin contributed a paper on the subject, of which the following is a résumé:-Radium has been found to emit three types of rays-(1) the $a$ rays, positively electrified and largely stopped by solid, liquid, or gaseous screens; (2) $\beta$ rays, more penetrative than $\alpha$ and negatively electrified; (3) $\gamma$ rays, electrically neutral and much more penetrative than either of the other two, passing with but little loss through a lead screen one centimetre thick, which is an almost perfect screen against the other rays. A simple prima facie view was to regard the $\gamma$ rays as mere vapour of radium; the $\beta$ rays seem certainly to be atoms of resinous electricity or electrons. The $a$ rays were atoms of molecules of matter, probably atoms of radium, or perhaps molecules of radium bromide. The electro-ethereal hypothesis afforded a ready explanation of the relative penetrating power of the three radiations, and of the fact that each one of them made its existence known to us by conferring electric conductivity on air or on any ordinary gas on which it was present. Taking the $\boldsymbol{\gamma}$ rays first, we had to explain the free penetration of unelectrified radium molecules through dense liquid and solid matter. An easy assumption sufficed. Let the Boscovichian mutual forces - that was, the chemical affinities and the repulsions-between an atom of radium 
and the atoms of lead and other permeable substances be absolutely zero or small enough to allow the known permeation. Taking next the $\alpha$ radiation, the apparent great absorption of the vitreous electric emanation from radium was only apparent. It meant that an atom shot from radium with less than its neutralizing quantum of electrons could not go far through a solid or liquid without acquiring the neutralizing quantum. The $\beta$ absorption might be regarded as probably real. Atoms of resinous electricity shot from radium could not be expected to enter a screen of metal, glass, or wood, or liquid, and leave at the other side, irrespectively of the insulation of the screen and of the radium. The full consideration and experimental investigation of the emission of atoms of resinous electricity from radium hermetically sealed in a glass bulb or tube led to surprising and interesting results. As to the $\boldsymbol{\gamma}$ rays, there was no difficulty in supposing that non-electrified vapour of radium passed very freely through metals or glass without any electric disturbance. It had been published that loss of weight in the course of a few months had been proved. Returning to Becquerel's original discovery in respect to uranium - the electric conductivity induced in air and other gases by a radio-active substance-there was a ready explanation in the resuscitation of the old doctrine of Epinus. The ordinary thermal motions within any solid, liquid, or gas must cause occasional shootings out of electrons from the substance, 
and the motion of these electrons, under the influence of electrostatic force, must contribute to the electric conductivity of the gas; must, in fact, constitute all of it which was not due to transport of atoms of the gas carrying less than the neutralizing quantum of electrons. Thus every substance must possess radio-activity, ${ }^{1}$ said Lord Kelvin. Some interesting remarks would be found in the Philosophical Magazine, where it was pointed out that radium was three hundred million times more active than the most active common material yet experimented with.

How was this enormous radio-activity of radium to be accounted for? Lord Kelvin suggested that it might be because it was exceedingly polyelectronic; that the saturating quantum of electrons in an atom of radium might be hundreds or thousands or millions of times as many as those of atoms of ordinary material. But this left the mystery of radium untouched-Curie's discovery that it perpetually emitted heat at a rate of about 90 Centigrade calories per gramme per hour. If emission of heat at this rate went on for little more than a year, or, say, ten thousand hours, there was as much heat as would raise the temperature of 900,000 grammes of water $1^{\circ} \mathrm{C}$. It seemed to Lord Kelvin utterly impossible that this

${ }_{1}$ Even the pigment of Micrococcus glutinis is radio-active; and also the chromoplastids of Helianthus, Verbena, and Geranium. (See A. B. Griffiths' papers in Chemical Nevos, vol, xci. p. 97 ; Berichte der deutschen chemischen Gesellschaft, vol. xxxvi., p. 3959.) 
could come from a store of energy lost out of a gramme of radium in ten thousand hours. It seemed to him, therefore, absolutely certain that if emission of heat at the rate of 90 calories per gramme per hour, found by Curie at ordinary temperatures, or even at the rate of 38 , found by Sir James Dewar and Monsieur Curie from a specimen of radium at the temperature of liquid oxygen, could go on for month after month, energy must somehow be supplied from without, to give the energy of the heat getting into the material of the calorimetric apparatus. It was suggested that somehow ethereal waves might supply energy to the radium while it was giving out heat to the ponderable matter around it. Think of a piece of black cloth hermetically sealed in a glass case and sunk in a glass vessel of water exposed to the sun, and think of another equal and similar glass case containing white cloth submerged in an equal and similar glass vessel of water, similarly exposed to the sun. The water in the former glass vessel would be kept very sensibly warmer than the water in the latter. This was analogous to Curie's first experiment, in which he found the temperature of a thermometer with a little tube containing radium kept beside its bulb in a little bag of soft material to be permanently about $2^{\circ} \mathrm{C}$. higher than that of another equal and similar thermometer, similarly packed with a little glass tube not containing radium beside its bulb. By changing the water in the two glass vessels a calorimetric 
investigation might be made, showing how much heat was given out per hour by the black cloth to the surrounding glass and water. Here thermal energy was communicated to the black cloth by waves of sunlight, and given out as thermometric heat to the glass and water around it. Thus, through the water, there was actually energy travelling inwards, in virtue of waves of light, and outwards through the same space in virtue of thermal conduction. This suggestion respecting radium might be regarded as utterly unacceptable, but, at all events, Lord Kelvin thought it would be conceded that experiments should be made comparing the thermal emission from radium wholly surrounded with thick lead with that found with the surroundings hitherto used. . . . Such were Lord Kelvin's ideas concerning radium. 


\section{INDEX}

LAVOISIER

Frontispiece

Death Warrant of Lavoisier .

Baron Cuvier?.

Cavendish and Cavendish House

Priestley and His Statue

LinNeUU .

Sir Richard Owen and Sheen Lodge .

Liebig and the Giessen Laboratory in 1840 .

Sir Charleg liell, Bart.

Dalton and His Tomb .

MENDELÉEFF

Count Buffon .

Berthelot

Sir Humphry Davy, Bart.

Gay-Lusisac

175

LORD KELVIN 


\section{THE}

\section{AGE OF THE WORLD}

BY

J. LOGAN LOBLEY, F.G.S., F.R.G.S:

Late Professor of Physiography and Astronomy, City of London College;

AUTHOR OF

\section{MOUNT VESUVIUS}

Ist Edition Dedicated by Special Permission to His Majesty the late King of Italy.

Demy 8vo, tastefully printed on superior paper and appropriately bound in cloth extra gilt, with Maps, and numerous Illustrations on plate paper.

3rd Edition, enlarged and brought up to date, with latest map of Vesuvius, by permission of Karl Baedeker.

12s. 6d. net.

\section{THE PARISHES OF ENGLAND}

Part I. - Middlesex and the Administrative County of London.

Giving the Areas, Surface, Subsoils, Density of Population, etc., of the Parishes of Middlesex and the Administrative County of London outside the City. Compiled and calculated from the Results of the Ordnance and Geological Surveys and the Census Returns. Gilt.

\section{VOLCANIC ACTION \& EARTHQUAKES}

Demy 8vo. Cloth. 5s. net.

\section{THE GEOLOGY OF EALING}

ILLUSTRATED.

Demy 8vo. Cloth gilt. 5s. net.

LONDON

ROBERT SUTTON

WALPOLE HOUSE, 28 HENRIETTA STREET, W.C. 


\title{
Four English Philosophers of the
}

\section{Nineteenth Century}

\author{
Illustrated
}

By

A. B. Griffiths, Ph.D.

Gold Medallist and Hon. Member of the Royal Academy of Sciences of Lisbon; Hon. Member of the Academy of Sciences of Montpellier; Gold Medallist of the Academie Nationale de Paris; Hon. Member of the Societies of Sciences of Bucharest, Mexico, Biarritz, and Rio Janeiro; Author of "Biographies of Scientific Men," "Respiratory Proteids," "The Physiology of the Invertebrata,"

"A Manual of Bacteriology," "Researches on Micro-organisms," etc., etc.

\section{LONDON}

\section{ROBERT SUTTON}

WALPOLE HOUSE, 28 HENRIETTA STREET, W.C. 


\section{MANURES}

FOR

\section{FRUIT \& OTHER TREES}

A Practical Handbook for the Gardener,

Horticulturist and Student

BY

\section{A. B. GRIFFITHS, Pн.D.}

Member of the Chemical Societies of Paris, Berlin, St Petersburg, and Milan; Gold Medallist aud Hon. Member of the Royal Academy of

Sciences of Lisbon; Hon. Member of the National Society of

Agriculture of Brazil; Gold Medallist and Hon. Member of

the Royal Society of Horticulture and Agriculture of

Tournai; Hon. Member of the Societies of Sciences

of Bucharest, Mexico, Biarritz, and Rio Janeiro;

Hon. Member of the Academy of Sciences of

Montpellier; Author of "A Treatise on

Manures," "Special Manures for

Garden Crops," "Manures and

their Uses," "The Diseases of

Crops," "A Manual of

Bacteriology," etc., etc.

\section{LONDON}

ROBERT SUTTON

WALPOLE HOUSE, 28 HENRIETTA STREET, W.C. 


\section{THE PROPAGATION}

\section{PLANTING \& PRUNING}

OF

\section{FRUIT \& OTHER TREES}

A Practical Handbook for the Gardener,

Horticulturist and Student

BY

J. C. NEWSHAM, F.L.S.

Medallist of the Scottish Horticultural Association; Headmaster and Manager of the Hampshire County Council Agricultural and Horticultural

School; Author of "The Horticultural Note-Book."

With Numerous Illustrations

LONDON

ROBERT SUTTON

WALPOLE HOUSE, 28 HENRIETTA STREET, W.C. 


\section{STUDIES}

IN THE

\section{APOCRYPHAL GOSPELS}

OF

\section{CHRIST'S INFANCY}

BY THE REV.

\section{DE LACY O'LEARY, D.D.}

Lecturer in Aramaic and Syriac, Bristol University; Author of

"Apostolic Constitutions," "Daily Office and Thestokia

of Coptic Church," "The Sacrament of

Holy Baptism," etc.

\section{LONDON}

\section{ROBERT SUTTON}

WALPOLE HOUSE, 28 HENRIETTA STREET, W.C. 



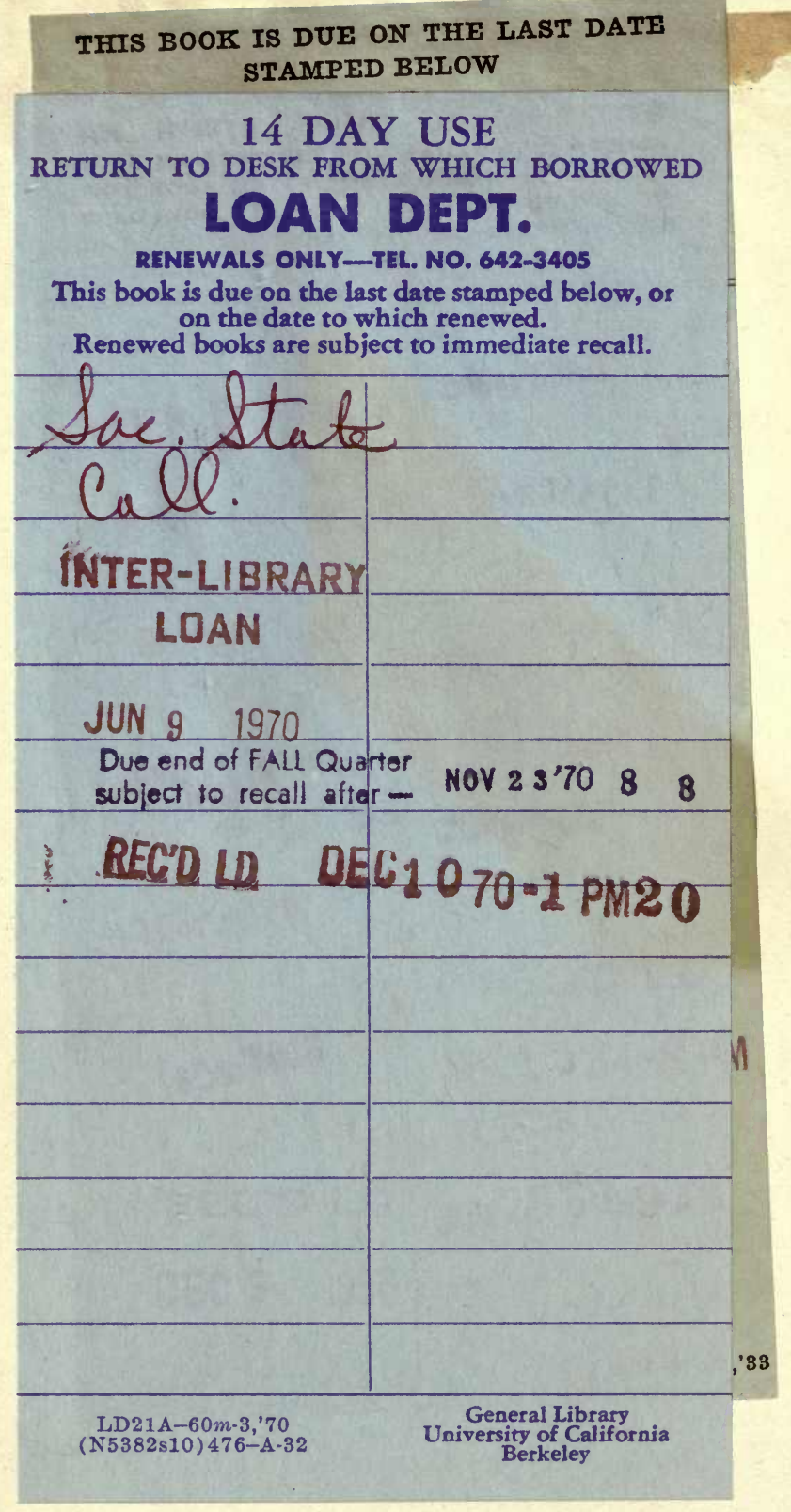




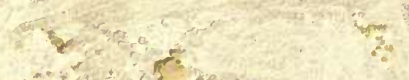

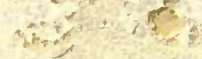

2isment?

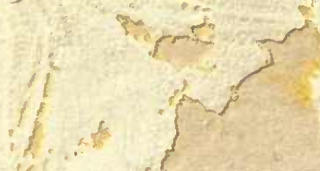

$=\left\{\begin{array}{l}5 \\ 5\end{array}\right.$

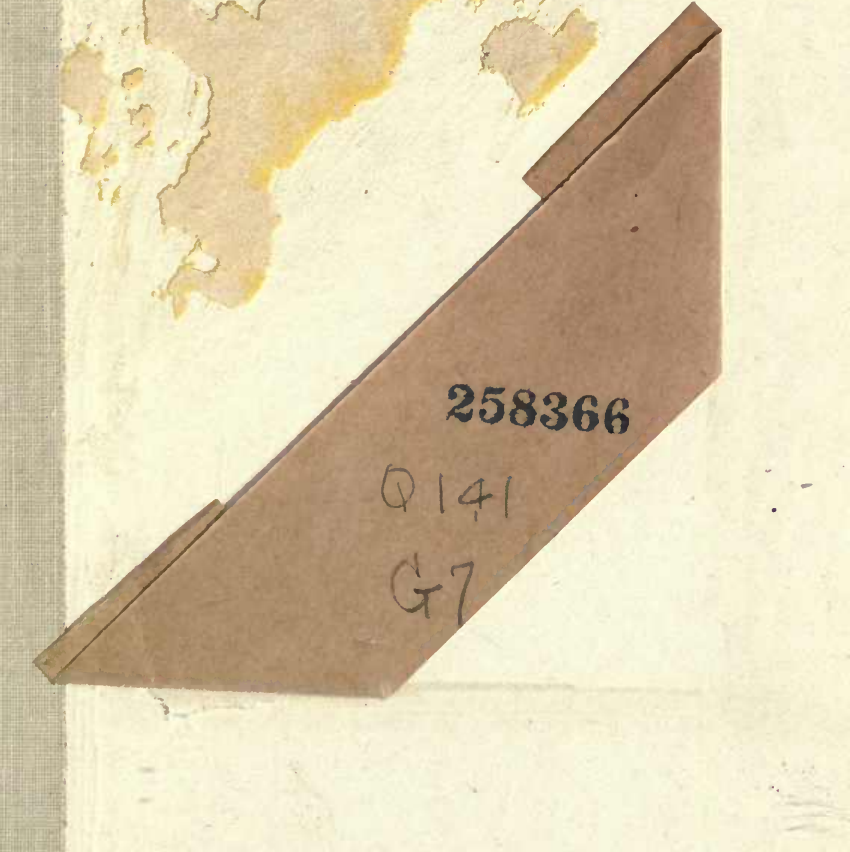


